\title{
TEXAS
}

WATER

DEVELOPMENT

$B O A R D$

Documents Department DEC9 1971

Dallas Pablic Librarg

Report 135

\section{GROUND-WATER RESOURCES OF CASS AND MARION COUNTIES, TEXAS}


TEXAS WATER DEVELOPMENT BOARD

REPORT 135

GROUND-WATER RESOURCES OF CASS AND

MARION COUNTIES, TEXAS

\author{
By \\ Mathew E. Broom \\ United States Geological Survey
}

\footnotetext{
Prepared by the U.S. Geological Survey in cooperation with the

Texas Water Development Board
} 


\section{TEXAS WATER DEVELOPMENT BOARD}

W. E. Tinsley, Chairman

Robert B. Gilmore

Milton T. Potts

\author{
Marvin Shurbet, Vice Chairman \\ John H. McCoy \\ Carl Illig
}

Harry P. Burleigh, Executive Director

Authorization for use or reproduction of any material contained in this publication, i.e., not obtained from other sources, is freely granted without the necessity of securing permission therefor. The Board would appreciate acknowledgement of the source of original material so utilized.

Published and distributed

by the

Texas Water Development Board

Post Office Box 13087

Austin, Texas 78711 


\section{TABLE OF CONTENTS}

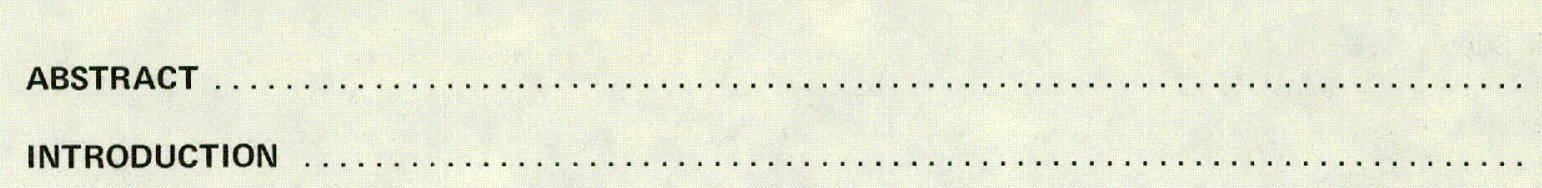

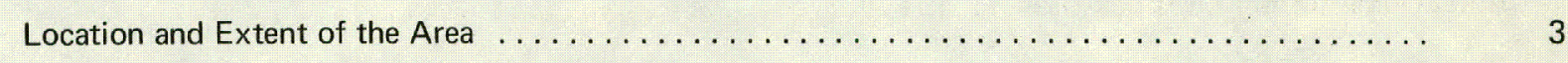

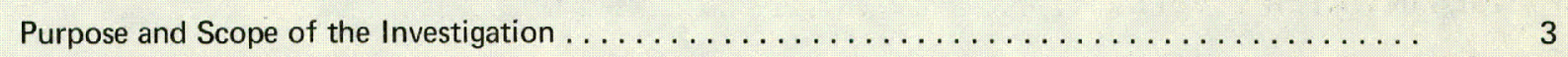

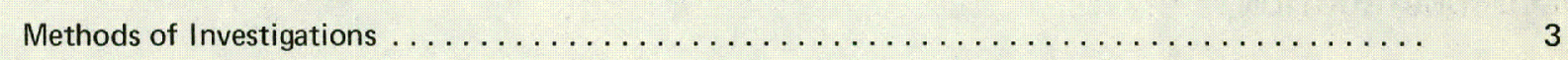

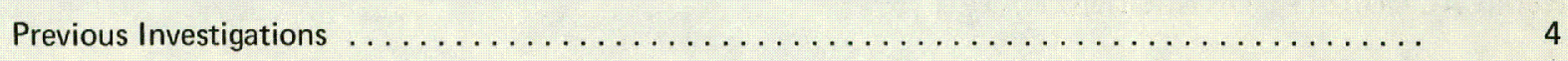

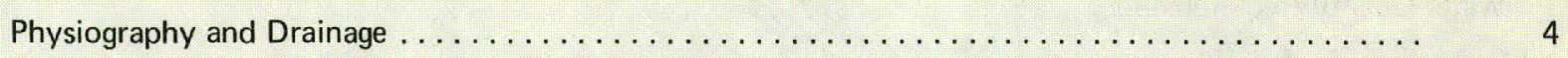

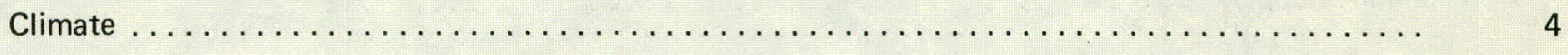

Population and Economy $\ldots \ldots \ldots \ldots \ldots \ldots \ldots \ldots \ldots \ldots \ldots \ldots \ldots \ldots \ldots \ldots \ldots \ldots \ldots \ldots \ldots \ldots \ldots \ldots \ldots \ldots$

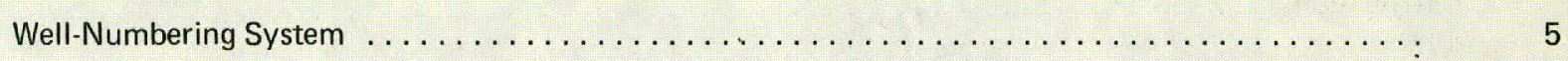

GEOLOGY AS RELATED TO GROUND WATER $\ldots \ldots \ldots \ldots \ldots \ldots \ldots \ldots \ldots \ldots \ldots \ldots \ldots \ldots \ldots \ldots \ldots \ldots \ldots$

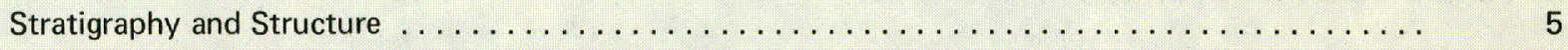

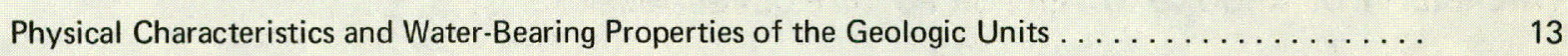

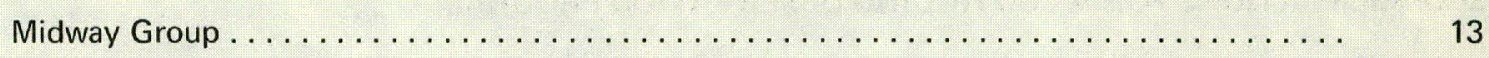

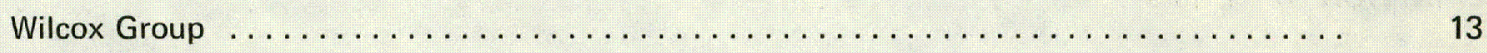

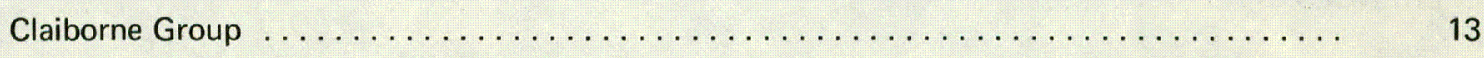

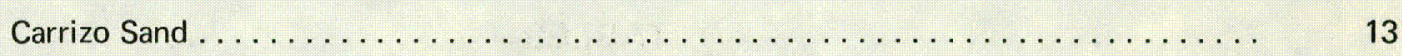

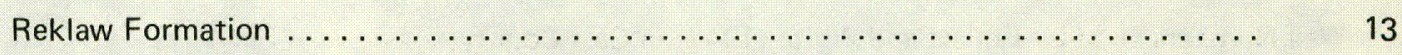

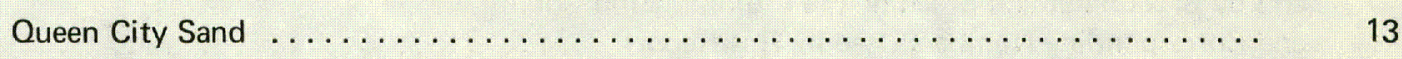

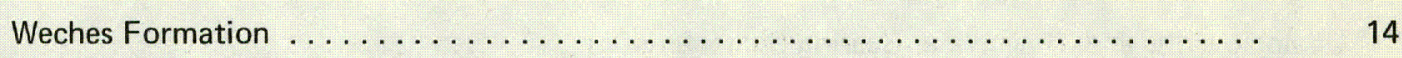

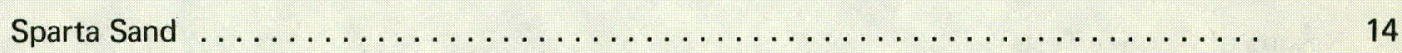

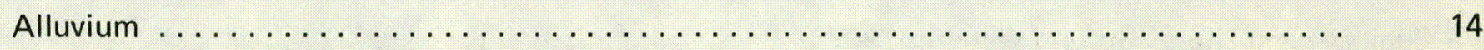

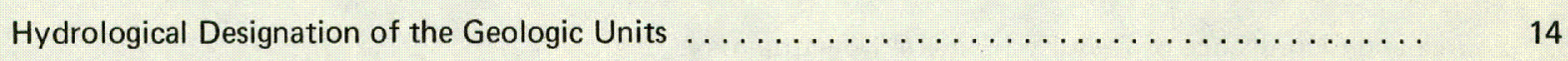

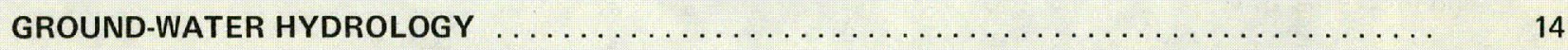

Occurrence and Movement of Ground Water $\ldots \ldots \ldots \ldots \ldots \ldots \ldots \ldots \ldots \ldots \ldots \ldots \ldots \ldots \ldots \ldots \ldots \ldots \ldots \ldots \ldots$ 


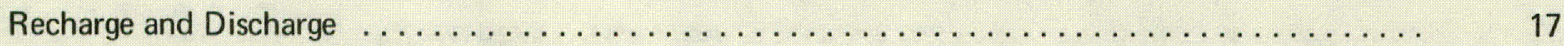

Hydraulic Properties of the Cypress Aquifer . . . . . . 17

USE AND DEVELOPMENT OF GROUND WATER $\ldots \ldots \ldots \ldots \ldots \ldots \ldots \ldots \ldots \ldots \ldots \ldots \ldots \ldots \ldots \ldots \ldots$

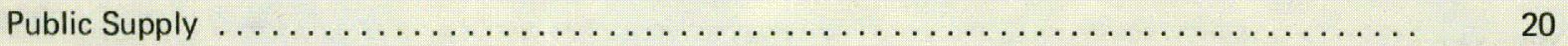

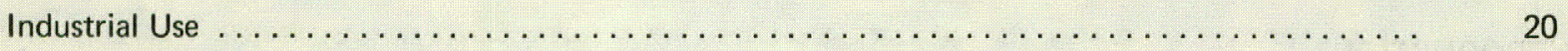

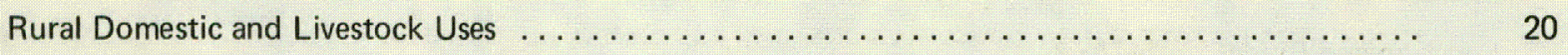

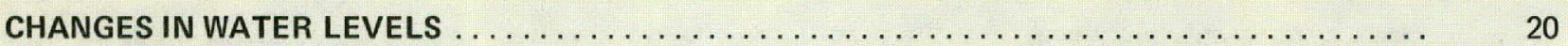

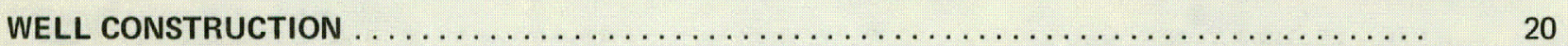

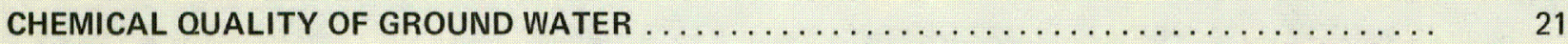

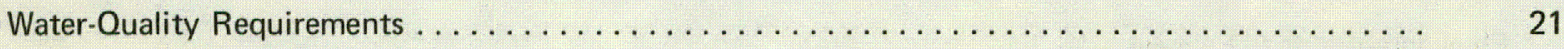

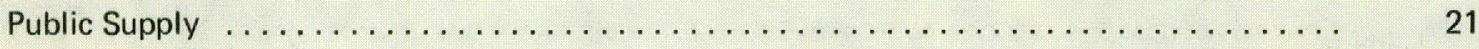

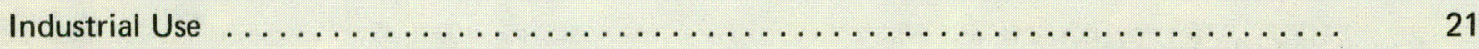

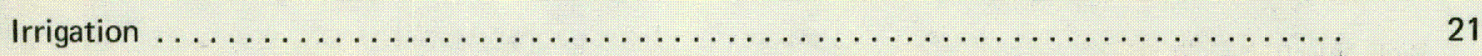

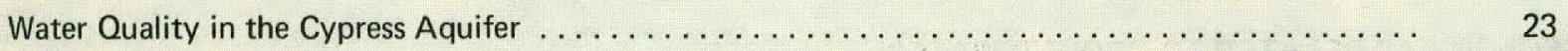

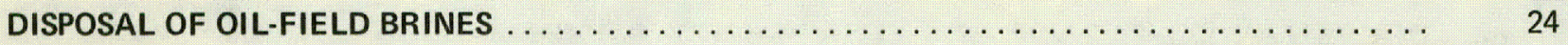

AVAILABILITY OF GROUND WATER FOR FUTURE DEVELOPMENT $\ldots \ldots \ldots \ldots \ldots \ldots \ldots \ldots \ldots \ldots$

RECOMMENDATIONS FOR A CONTINUING OBSERVATION PROGRAM $\ldots \ldots \ldots \ldots \ldots \ldots \ldots \ldots .28$

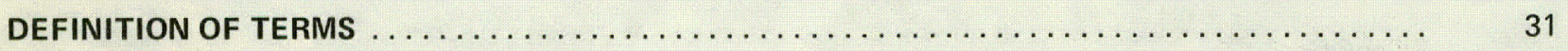

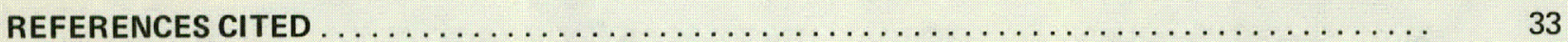

\section{TABLES}

1. Well Numbers Used by Follett and White (1942) in Cass County, and by Broadhurst and Breeding (1943b) in Marion County,

and Corresponding Numbers Used in This Report $\ldots \ldots \ldots \ldots \ldots \ldots \ldots \ldots \ldots \ldots \ldots \ldots \ldots \ldots \ldots \ldots$

2. Geologic Units and Their Water-Bearing Characteristics $\ldots \ldots \ldots \ldots \ldots \ldots \ldots \ldots \ldots \ldots \ldots \ldots \ldots \ldots \ldots \ldots$

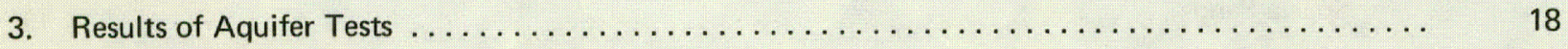

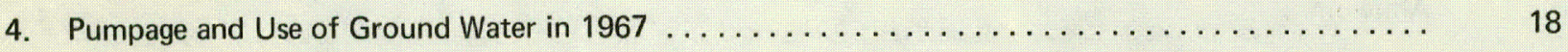

5. Source and Significance of Dissolved-Mineral Constituents
and Properties of Water $\ldots \ldots \ldots \ldots \ldots \ldots \ldots \ldots \ldots \ldots \ldots \ldots \ldots \ldots \ldots \ldots \ldots \ldots \ldots \ldots$

6. Oil- and Gas-Field Brine Production and Disposal, $1967 \ldots \ldots \ldots \ldots \ldots \ldots \ldots \ldots \ldots \ldots \ldots \ldots \ldots \ldots \ldots \ldots \ldots \ldots \ldots$

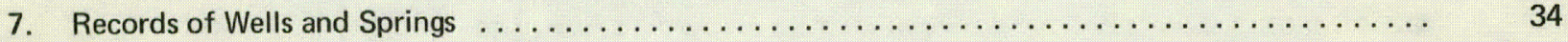




\section{TABLE OF CONTENTS (Cont'd.)}

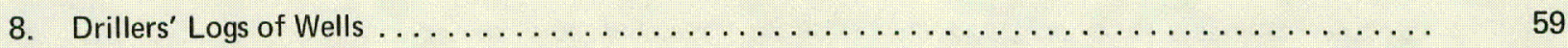

9. Chemical Analyses of Water from Wells and Springs $\ldots \ldots \ldots \ldots \ldots \ldots \ldots \ldots \ldots \ldots \ldots \ldots \ldots \ldots \ldots \ldots \ldots \ldots$

\section{FIGURES}

1. Map of Texas Showing Location of Cass and Marion Counties $\ldots \ldots \ldots \ldots \ldots \ldots \ldots \ldots \ldots \ldots \ldots \ldots \ldots$

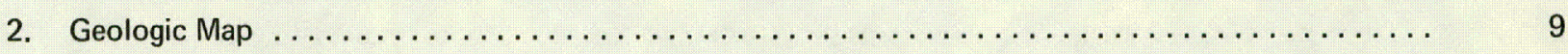

3. Map Showing Approximate Altitude of and Depth to the Top of the Midway Group ........... 11

4. Map Showing Altitudes of Water Levels in the Cypress Aquifer, $1967-68 \ldots \ldots \ldots \ldots \ldots \ldots \ldots \ldots \ldots$

5. Graph Showing Relation of Drawdown to Distance and Time, Water-Table Conditions .......... 19

6. Graph Showing Relation of Drawdown to Distance and Time, Artesian Conditions ............ 19

7. Map Showing Depths of Wells and Chloride and Dissolved-Solids Content of Water from Selected Wells Tapping the Cypress Aquifer $\ldots \ldots \ldots \ldots \ldots \ldots \ldots \ldots \ldots \ldots \ldots \ldots$

8. Map Showing Approximate Thickness of Sand Containing

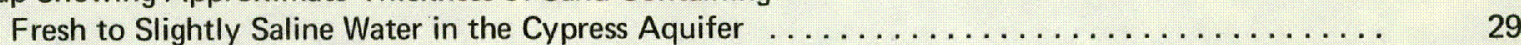

9. Map Showing Locations of Wells, Springs, and Oil and Gas Fields $\ldots \ldots \ldots \ldots \ldots \ldots \ldots \ldots \ldots \ldots \ldots \ldots$

10. Chart Showing Correlation of Geologic Units Along Line A-A $\ldots \ldots \ldots \ldots \ldots \ldots \ldots \ldots \ldots \ldots$

11. Chart Showing Correlation of Geologic Units Along Line B-B' $\ldots \ldots \ldots \ldots \ldots \ldots \ldots \ldots \ldots \ldots \ldots$

12. Chart Showing Correlation of Geologic Units Along Line C-C' $\ldots \ldots \ldots \ldots \ldots \ldots \ldots \ldots \ldots \ldots \ldots$ 



\title{
GROUND-WATER RESOURCES OF CASS AND \\ MARION COUNTIES, TEXAS
}

\begin{abstract}
Cass and Marion Counties, an area of 1,325 square miles in northeast Texas, are underlain by the Cypress aquifer which is composed of the Wilcox Group, Carrizo Sand, Reklaw Formation, and Queen City Sand, all of Eocene age. These geologic units are for the most part hydraulically interconnected and generally function as a single aquifer.

As a result of ground-water development, water levels in the artesian section of the aquifer have declined as much as 109 feet since 1964. Three areas in Cass and Marion Counties have been significantly affected by pumping, but elsewhere in the report area, water levels show no appreciable change. Pumpage of ground water in 1967 was $3.6 \mathrm{mgd}$ (million gallons per day) or about 4,000 acre-feet.

The Cypress aquifer is capable of sustaining additional development. About $8.5 \mathrm{mgd}$ of ground water is currently moving through the aquifer, and probably an

rejected to streams as base flow. Current pumpage probably could be increased to more than four times the present rate without exceeding the rate of ground-water replenishment or depleting the supply. About 90 million acre-feet of fresh to slightly saline water is stored in the Cypress aquifer. Of that amount, 50 million acre-feet is available within 400 feet of the land surface. In areas where saturated sands are more than $\mathbf{4 0 0}$ feet thick, wells are capable of yielding $\mathbf{5 0 0}$ or more gpm (gallons per minute).

Water in the Cypress aquifer generally is fresh and is soft. In most of the areas, water suitable for public supply, irrigation, and many industrial uses is available for development. However, in places in the southern and northern parts of the area, chloride concentrations are high. Excessive concentrations of dissolved iron exist at generally predictable depths within the aquifer, and by proper well construction and pumping practices, the water of high iron content can be avoided.
\end{abstract} equal or greater quantity of potential recharge is being 


\section{GROUND-WATER RESOURCES OF CASS AND MARION COUNTIES, TEXAS}

\section{INTRODUCTION}

\section{Location and Extent of the Area}

Cass and Marion Counties in northeast Texas are bordered by Bowie County on the north; Morris and Upshur Counties on the west; Harrison County on the south; and Miller County, Arkansas and Caddo Parish, Louisiana on the east (Figure 1). The two counties have an area of 1,325 square miles, of which 950 are in Cass County and 375 are in Marion County.

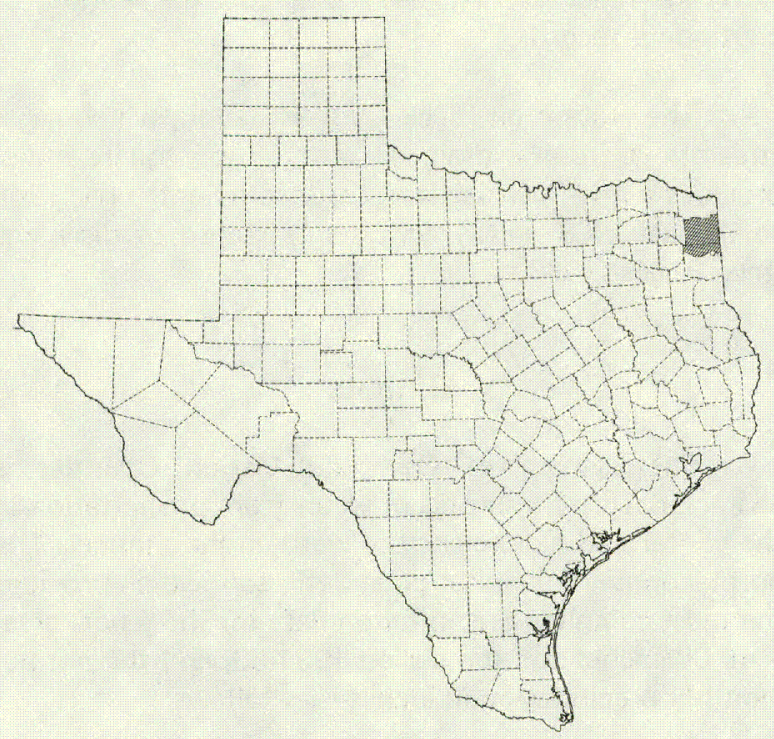

Figure 1.-Location of Cass and Marion Counties

\section{Purpose and Scope of the Investigation}

The purpose of the investigation was to determine and describe the ground-water resources of Cass and Marion Counties. The investigation was begun in 1967 by the U.S. Geological Survey in cooperation with the Texas Water Development Board.

Information was obtained on the occurrence, availability, dependability, quality, and quantity of ground-water resources. In this report, data are presented to show the vertical and lateral extent of the principal aquifer, the hydrologic properties of the aquifer, and the chemical quality of water in the aquifer. The report gives the quantities and uses of the ground water being withdrawn and the effects of these withdrawals on water levels. Problems associated with ground-water development are discussed and estimates are given on the quantity of ground water available for future development.

\section{Methods of Investigation}

The investigation was achieved largely through the cooperation of well owners and county, city, and industrial officials who allowed access to their property and permitted examination of pertinent records. Most of the data were collected during the period from October 1967 through June 1968. Basic information, including depths of wells, water levels, methods of well construction and water lift, yield characteristics, and use of water, was collected for 311 wells. Information previously collected by the U.S. Geological Survey and the Texas Water Development Board was updated. The locations of wells and springs are shown on Figure 9.

The static water levels in most wells and all water levels used for primary control points for the potentiometric map (Figure 4) were measured with a steel tape. Static water levels in other wells were reported by well owners or drillers. The altitudes of the land surface at the wells were determined either by altimeter measurements or by interpolation from U.S. Geological Survey $7 \frac{1}{2-}$ and 15 -minute quadrangle topographic maps (contour intervals, 10 to 20 feet). All of Marion County and about one-half of Cass County is covered by recent $7 \frac{1}{2}$-minute quadrangle topographic maps, and these maps generally provided sufficient horizontal and vertical control. The rest of the area in Cass County is covered by 15-minute quadrangle topographic maps published in 1907. Altitudes for critical control points in this area were obtained or checked with an altimeter.

Water samples were collected from 52 wells during this investigation. The records of chemical analyses are shown in Table 9 and include the results of additional analyses of water sampled from wells and springs during previous investigations. Water samples from five wells in the report area were analyzed for pesticides. 
Ground-water pumpage for public supply and industrial use during 1967 (Table 4) was obtained from records provided by municipal and industrial officials. Pumpage for domestic and livestock use was estimated.

The geologic map (Figure 2) was taken largely from the Tyler and Texarkana sheets of the Geologic Atlas of Texas (Bureau of Economic Geology, 1964 and 1966). Subsurface control for the charts showing correlation of the geologic units (Figures 10,11, and 12), for the map showing the altitude of and depths to the top of the Midway Group (Figure 3), and for the map showing the saturated sand thickness of the Cypress aquifer (Figure 8), was obtained from electrical logs of oil, gas, and water tests. Additional subsurface information was obtained from drillers' logs of water wells, a representative number of which are given in Table 8.

Aquifer tests (Table 3 ) were analyzed by the Theis nonequilibrium method as modified by Cooper and Jacob (1946), and by the Theis recovery method (Wenzel, 1942).

\section{Previous Investigations}

Deussen (1914), in his report on the geology and underground waters of the southeastern part of the Texas Coastal Plain, included a brief account of groundwater reservoirs and development in Marion County. The geology of the report area was described in a report by Sellards and others (1932) on the regional geology of Texas.

Follett and White (1942) made an inventory of wells and springs and reproted on ground-water development in Cass County. Broadhurst and Breeding (1943b) made an inventory of wells and springs and reported on ground-water development and stream runoff in Marion County. Sundstrom and others (1948), in a report on the public water supplies in eastern Texas, included information on the water supplies at Atlanta, Avinger, Hughes Springs, and Linden in Cass County, and at Jefferson in Marion County. Baker and others (1963), in a reconnaissance report on the ground-water resources of the Red River, Sulphur River, and Cypress Creek basins included information pertinent to the report area.

Detailed ground-water investigations in Texas in counties adjacent to the report area have been made in Harrison County (Broadhurst and Breeding, 1943a, and Broom and Myers, 1966); Camp, Franklin, Morris, and Titus Counties (Broom and others, 1965); and Gregg and Upshur Counties (Broom, 1969).

\section{Physiography and Drainage}

Cass and Marion Counties are in the West Gulf Coastal Plain of eastern Texas (Fenneman, 1938). The land surface, which slopes generally southeastward, supports a substantial growth of pine and hardwood. The area is drained by Sulphur River in the north and by Big Cypress Bayou in the south. However, the drainage to the two streams is unequally distributed because the drainage divide is in the northern part of Cass County, about on a line extending eastward from Marietta to Queen City; consequently, about 75 percent of the area is drained by Big Cypress Bayou and its tributaries. Except for the relatively flat flood plains of the principal streams, the terrain is gently rolling to hilly. Altitudes range from about 600 feet above mean sea level on the Sulphur River-Big Cypress Bayou drainage divide to about 170 feet along the downstream reaches of Big Cypress Bayou.

The U.S. Geological Survey maintains streamgaging stations on Frazier Creek near Linden (7-3461.4) and Black Cypress Bayou at Jefferson (7-3460.45). The locations of the gaging stations are shown on Figure 9. The station on Frazier Creek, which gages streamflow from a drainage area of 48 square miles, provides a low-flow partial record from August 1958 to June 1961 and a continuous discharge record since November 1964. Discharge at the Frazier Creek station ranged from 2,620 cfs (cubic feet per second) on April 24, 1966, to no flow at times during each year of the period of continuous record.

The station on Black Cypress Bayou, which gages streamflow from a drainage area of 365 square miles, provides a low-flow partial record from September 1964 to August 1968 and a continuous record of discharge since August 1968.

\section{Climate}

The climate of Cass and Marion Counties is characterized by a surplus of water from precipitation in the winter and a deficiency of water in the summer. The normal annual precipitation at Jefferson, which provides the most complete precipitation data for the report area, is 46.00 inches for the period 1931-60, and the normal monthly precipitation in inches is as follows:

\begin{tabular}{|c|c|c|c|c|}
\hline January & 4.20 & May & 5.28 & September \\
\hline February & 4.03 & June & 3.02 & October \\
\hline arch & 3.93 & July & 3.26 & Vovember \\
\hline pril & 4.62 & August & 2.67 & ecember \\
\hline
\end{tabular}

Generous rainfalls occur in April and May and again in November and December. These are the two peak rainfall periods before and after the drier summer months.

The normal minimum January temperature is $2^{\circ} \mathrm{C}\left(36^{\circ} \mathrm{F}\right)$, and the normal maximum July 
temperature is $34^{\circ} \mathrm{C}\left(94^{\circ} \mathrm{F}\right)$. The average dates of the first and last killing frosts are November 9 and March 18, respectively. The mean annual growing season is 236 days.

The annual gross lake-surface evaporation in the report area during the period 1940-65 ranged from 39 inches in 1950 to 56 inches in 1954 and averaged 46 inches (Kane, 1967, p. 55, 64).

\section{Population and Economy}

The U.S. Bureau of the Census shows a population of 23,227 for Cass County and 8,091 for Marion County in 1970. The populations in 1970 of principal cities in Cass County were: Atlanta, 4,947; Hughes Springs, 1,644; and Linden, 1,994. In Marion County, Jefferson had a population of 2,703 in 1970.

The economy of the area is based on industry and agriculture. The leading industry in both Cass and Marion Counties is the production of petroleum and related products. The production of oil in Cass County in 1965 was $1,476,000$ barrels, and the cumulative production through 1965 was $72,574,600$ barrels. The production in Marion County in 1965 was 810,700 barrels, and cumulative production through 1965 was $31,096,700$ barrels (Railroad Commission of Texas, 1966). Other important industries in both counties include the production of lumber, pulpwood, and other wood products. Sales and services relating to water recreation and sports on Texarkana Reservoir, Lake O' the Pines, and Caddo Lake are important to the economy of the area.

Agriculture has evolved in recent years from predominantly row-crop farming to improved pastures and livestock. Beef cattle, poultry, and timber production provide most of the farm income. Other elements of the agricultural economy include minnow raising and production of fruits and vegetables.

\section{Well-Numbering System}

The well-numbering system used in this report was developed by the Texas Water Development Board for use throughout the State. Under this system, each 1-degree quadrangle is given a number consisting of two digits from 01 to 89. These are the first two digits in the well number, Each 1-degree quadrangle is divided into $7 \frac{1}{2}$-minute quadrangles which are given 2-digit numbers from 01 to 64 . These are the third and fourth digits of the well number. Each $71 / 2$-minute quadrangle is subdivided into $2 \frac{1}{2}$-minute quadrangles which are given a single digit number from 1 to 9 . This is the fifth digit of the well number. Finally, each well within a $2 \frac{1}{2} 2$-minute quadrangle is given a 2-digit number in the order in which it was inventoried, starting with 01 . These are the last two digits of the well number.
Only the last three digits of the well number are shown at the location of a well on Figure 9; the second two digits are shown near the northwest corner of each $7 \frac{1}{2}$-minute quadrangle; and the first two digits are shown by the large block numerals 16 and 35 .

In addition to the 7-digit well number, a 2-letter prefix is used to identify the county. The letter prefix for Cass County is DB, and for Marion County it is SX. Thus, well DB-16-62-701 (a well for the city of Linden) is in Cass County (DB), in the 1-degree quadrangle 16, in $7 \frac{1}{2}$-minute quadrangle 62 , in the $2 \frac{1}{2}$-minute quadrangle 7 , and was the first well inventoried in that $2 \frac{1}{2}$-minute quadrangle (Figure 9 ).

The well numbers used by authors of previous reports and the corresponding numbers used in this report are given in Table 1.

\section{GEOLOGY AS RELATED TO GROUND WATER}

\section{Stratigraphy and Structure}

Geologic units of Eocene age are the principal sources of ground water in Cass and Marion Counties. Rocks of Pleistocene and Holocene age would probably yield only small amounts of ground water. The geologic units and a summary of their water-bearing characteristics are given in Table 2 .

Except for the alluvium, which is localized mostly in the larger streambeds, the units tend to crop out in northeasterly-trending belts that lie within or border the report area on the north and south (Figure 2). From the northwest and southeast corners of the area, the units that compose the Cypress aquifer dip toward the interior at about 30 to 40 feet per mile. In the interior parts of the area, the dips of the units tend to flatten and become irregular. In the general direction of dip, each unit is successively overlain by a younger unit so that a body of sediments, mostly water-bearing, thickens from about 300 feet in the northwest and southeast corners of the report area to 1,100 feet or more in the interior.

The stratigraphic relationships of the geologic units are shown on Figures 10,11, and 12. Because of a general similarity in rock character, the contacts between the units often are difficult to determine from examination of drillers' and electrical logs; therefore, the contacts shown on Figures 10-12 and the thicknesses of the units shown in Table 2 are only approximate.

The base of fresh to slightly saline water in Cass and Marion Counties occurs at the top of the Midway Group. The Wilcox Group, the lowermost fresh waterbearing unit, contains more than half the available water-bearing sediments. Nearly all of the units above the Wilcox contain additional water-bearing sediments, 
Table 1.-Well Numbers Used by Follett and White (1942) in Cass County, and by Broadhurst and Breeding (1943b) in Marion County, and Corresponding Numbers Used in This Report

\begin{tabular}{|c|c|c|c|c|c|}
\hline $\begin{array}{l}\text { OLD } \\
\text { NUMBER }\end{array}$ & $\begin{array}{l}\text { NEW } \\
\text { NUMBER }\end{array}$ & $\begin{array}{l}\text { OLD } \\
\text { NUMBER }\end{array}$ & $\begin{array}{c}\text { NEW } \\
\text { NUMBER }\end{array}$ & $\begin{array}{l}\text { OLD } \\
\text { NUMBER }\end{array}$ & $\begin{array}{c}\text { NEW } \\
\text { NUMBER }\end{array}$ \\
\hline \multicolumn{6}{|c|}{ CASS COUNTY (DB) } \\
\hline 120 & $16-48-801$ & 230 & $16-59-601$ & 153 & $16-63-901$ \\
\hline 1 & $16-51-602$ & 232 & $16-59-602$ & 154 & $16-63-903$ \\
\hline 3 & $16-52-101$ & 250 & $16-59-901$ & 143 & $16-64-101$ \\
\hline 67 & $16-52-701$ & 63 & $16-60-101$ & 144 & $16-64-203$ \\
\hline 20 & $16-53-101$ & 60 & $16-60-201$ & 255 & $35-04-401$ \\
\hline 23 & $16-53-102$ & 233 & $16-60-501$ & 261 & $35-04-601$ \\
\hline 24 & $16-53-103$ & 236 & $16-60-601$ & 265 & $35-04-801$ \\
\hline 29 & $16-53-201$ & 235 & $16-60-801$ & 263 & $35-04-901$ \\
\hline 27 & $16-53-601$ & 306 & $16-61-601$ & 364 & $35-05-301$ \\
\hline 42 & $16-53-901$ & 305 & $16-61-602$ & 346 & $35-05-302$ \\
\hline 86 & $16-54-601$ & 201 & $16-62-301$ & 313 & $35-06-301$ \\
\hline 206 & $16-54-801$ & 310 & $16-62-501$ & 342 & $35-06-402$ \\
\hline 205 & $16-54-802$ & 304 & $16-62-701$ & 349 & $35-06-701$ \\
\hline 125 & $16-56-201$ & 191 & $16-63-201$ & 341 & $35-06-801$ \\
\hline 126 & $16-56-501$ & 148 & $16-63-601$ & 442 & $35-07-905$ \\
\hline 64 & $16-59-301$ & 172 & $16-63-801$ & 430 & $35-08-501$ \\
\hline \multicolumn{6}{|c|}{ MARION COUNTY (SX) } \\
\hline 31 & $35-14-502$ & 53 & $35-15-501$ & 10 & $35-20-201$ \\
\hline 15 & $35-14-704$ & 54 & $35-15-701$ & 13 & $35-21-501$ \\
\hline
\end{tabular}

and except for the alluvium, these units are assigned to the Claiborne Group.

The principal structural feature of the area is the East Texas Embayment, an elongate structural basin whose long axis trends northeasterly through Cass and Marion Counties. The configuration of the basin is shown by contours on top of the Midway Group (Figure 3). Two prominent lows or subbasins occur within the area. One underlies the Avinger area and is closed by the -800 -foot (below sea level) contour. The other subbasin underlies an area that extends southward from about Atlanta to Kildare, and is closed by the -600 -foot contour. A ridge that extends southward from about Douglassville to Jefferson divices the two subbasins. Altitudes on the ridge are -400 feet or higher.

The general structural patterns of the subbasins and the ridge are sharply altered in their southern reaches by the Rodessa Fault. This fault, which trends northeasterly, passes through the Jefferson and McLeod areas (Figures 2 and 3). The geologic units are downthrown on the south side of the fault. Vertical displacement ranges from less than 100 feet to 200 feet. A section across the fault between wells SX-35-15-203 and DB-35-06-803 is shown on Figure 12. As shown in the section, the Wilcox Group is partially displaced so that its basal part (downthrown side) is in vertical contact with the Midway Group; the Carrizo Sand is completely displaced and is in vertical contact with the upper part of the Wilcox; the Reklaw Formation is completely displaced and is in vertical contact with the uppermost part of the Wilcox and the lower half of the Carrizo. The Queen City Sand is partially displaced so that its basal part is in vertical contact with the upper half of the Carrizo and all of the Reklaw. The trace of the fault at the surface, which is mostly within the outcrop area of the Queen City, is obscure. 
Table 2.--Geologic Units and Their Water-Bearing Characteristics

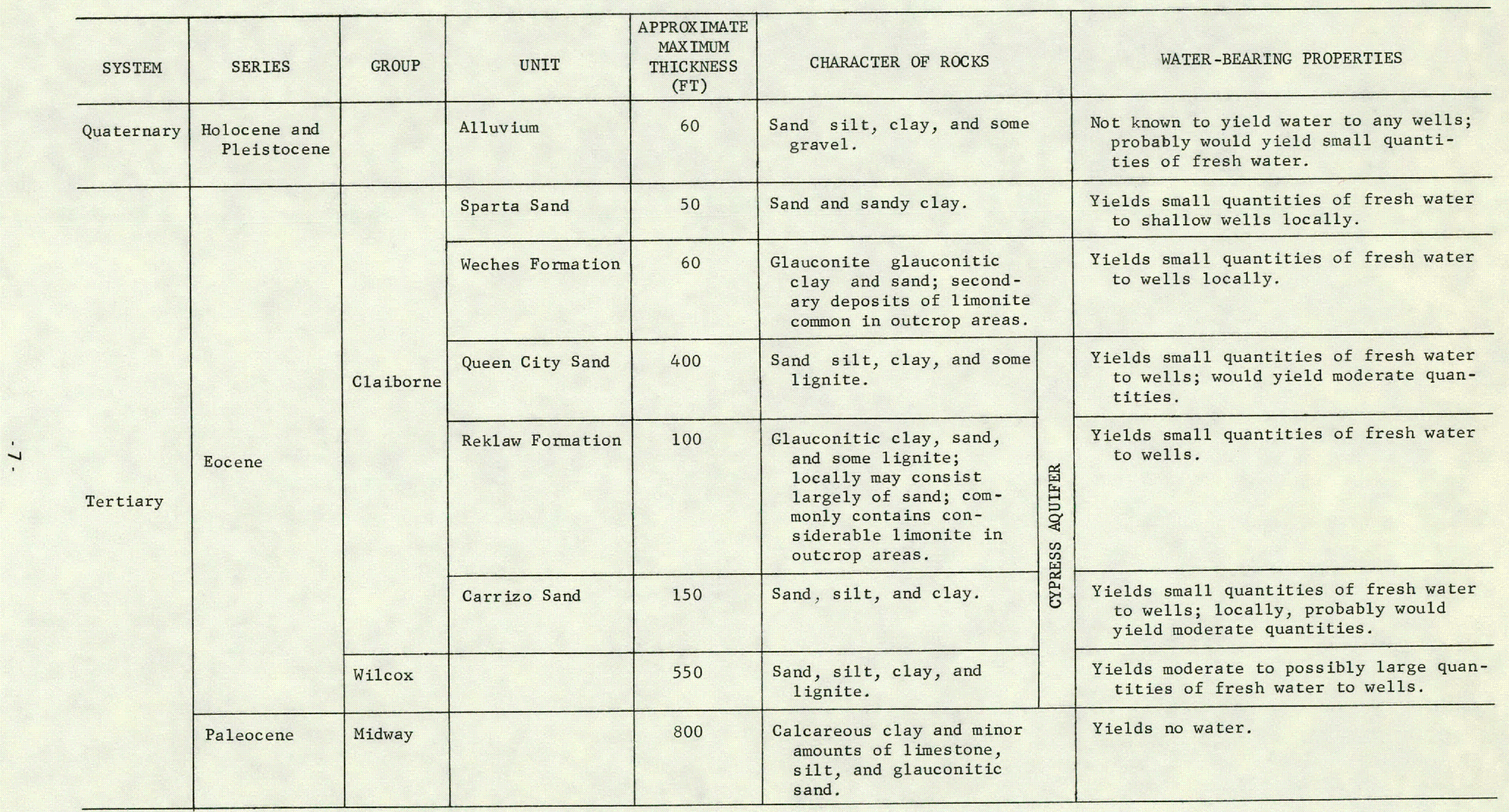




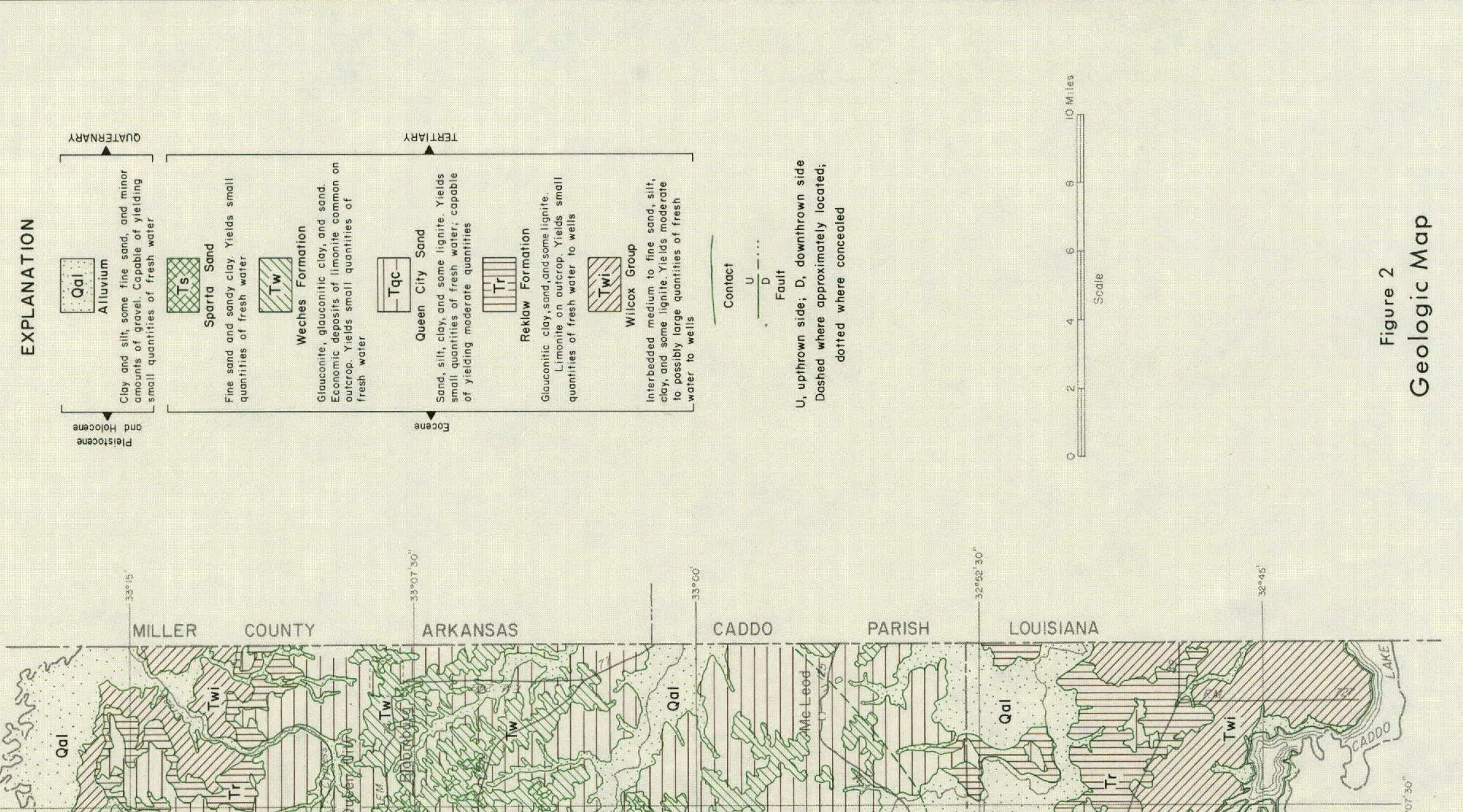

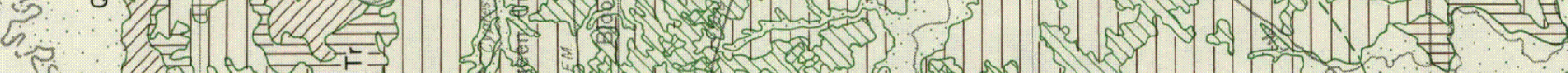

1.

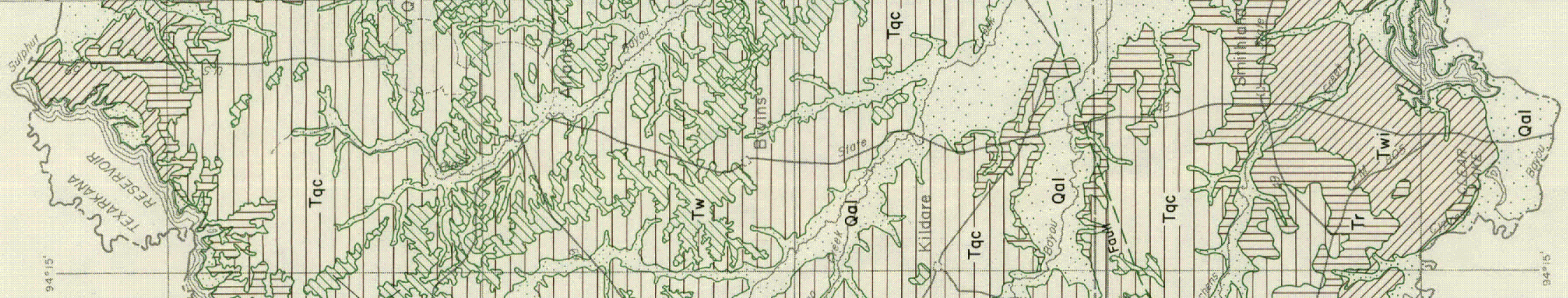

2.

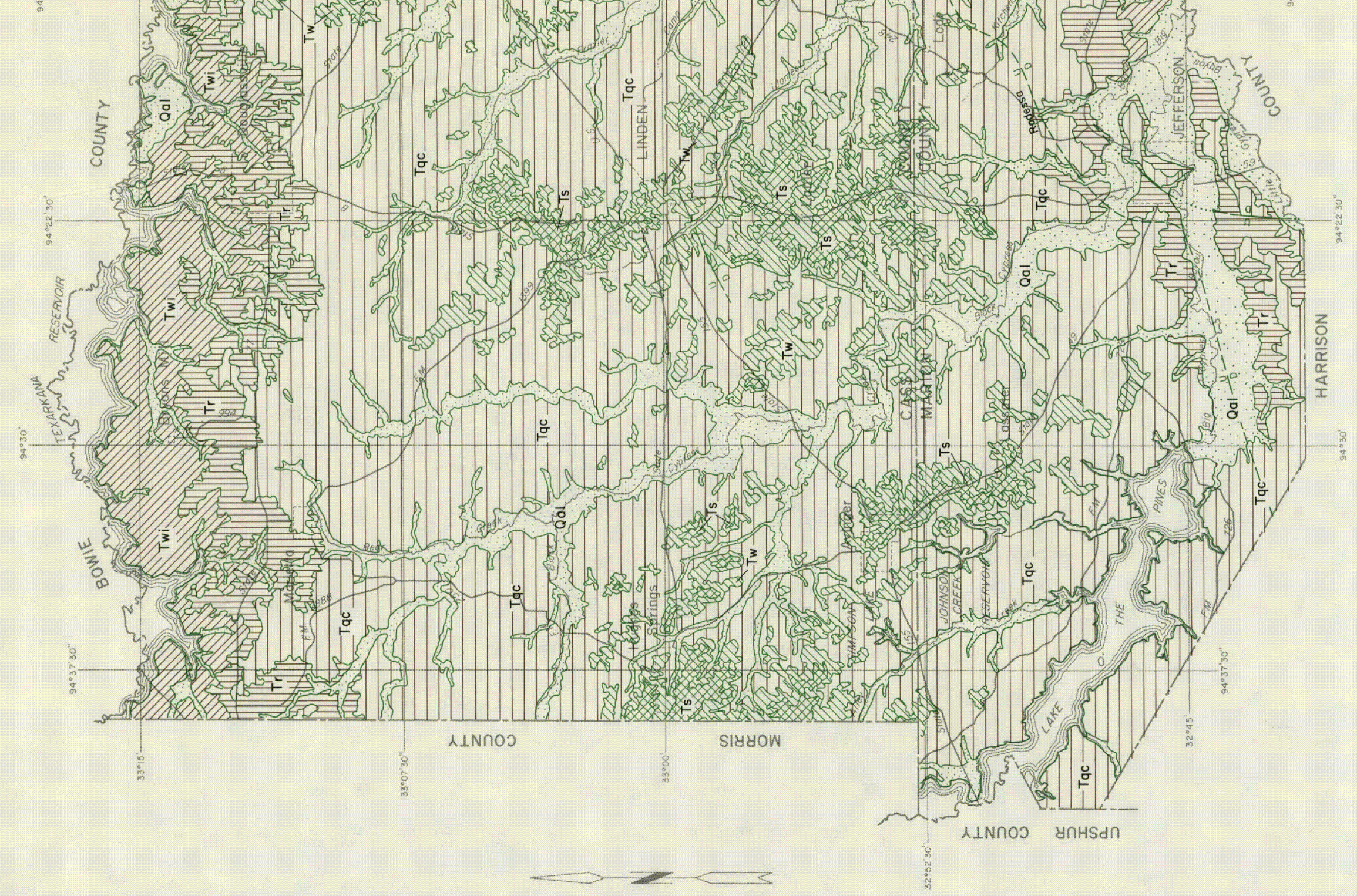





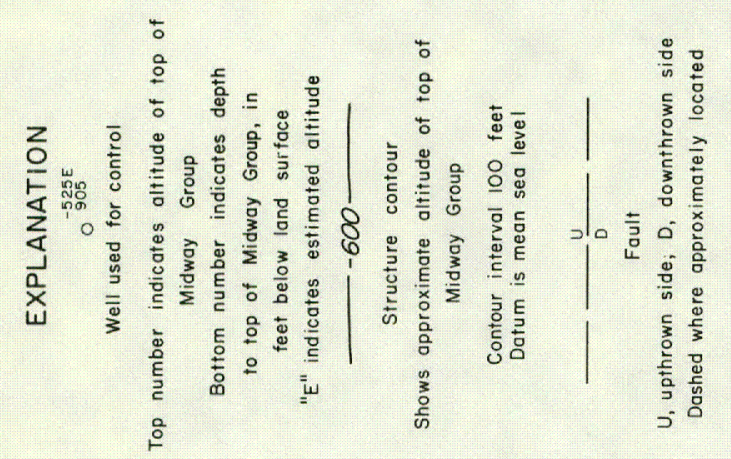
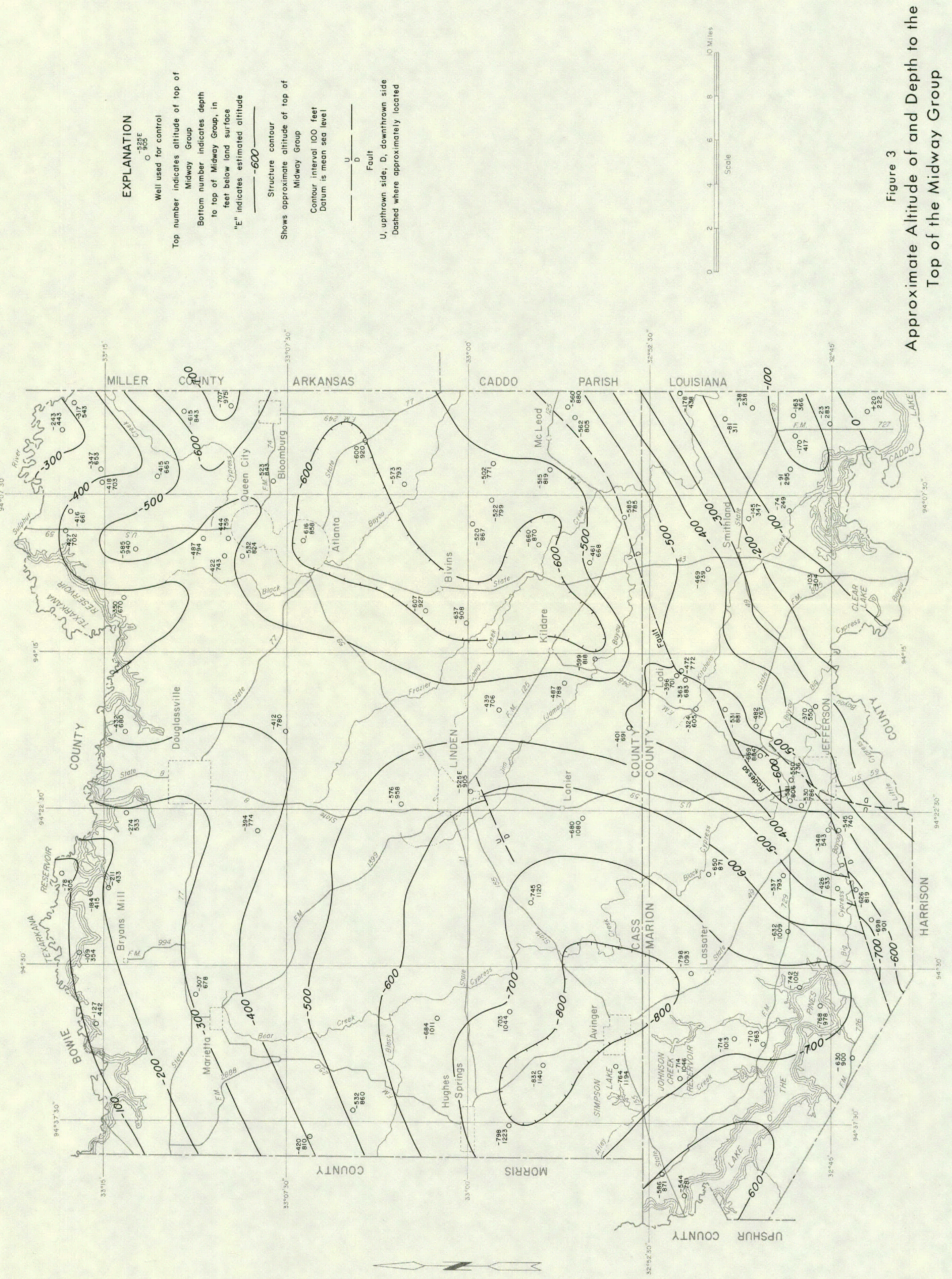



\section{Physical Characteristics and Water-bearing Properties of the Geologic Units}

\section{Carrizo Sand}

\section{Midway Group}

The Midway Group underlies all of Cass and Marion Counties and crops out in counties to the north and west. The unit has a maximum thickness of about 800 feet and is composed chiefly of calcareous clay. Locally the unit may contain some stringers of limestone and glauconitic sand, and generally the unit tends to become silty in the upper part of the section. The Midway does not yield water but is hydrologically important because its upper surface serves as relatively impermeable basement for the overlying water-bearing units in Cass and Marion Counties.

Altitudes of the top of the Midway (Figure 3) range from near sea level in the northwest and southeast corners to at least 832 feet below sea level near the center of the report area.

\section{Wilcox Group}

The Wilcox Group conformably overlies the Midway Group and crops out along the northern border of Cass County and in the southeastern part of Marion County (Figure 2). The outcrop area of the Wilcox is characterized by a nearly level to gently rolling land surface, mantled by a clayey- to sandy-textured soil.

The Wilcox is about 300 feet thich in the areas of outcrop, and is normally about 450 feet thick elsewhere. In the subbasins around Avinger, Atlanta, and Kildare, the Wilcox locally attains a maximum thickness of about 550 feet. Typically, the Wilcox is composed of interbedded sand, silt, clay, and some lignite. Medium to very fine quartz sand generally constitutes one-third to one-half of the unit. Individual beds of sand generally are thin bedded and discontinuous, although in the subbassins, some of the beds of sand attain thickness of nearly 100 feet (well DB-35-04-501, Figure 11).

Because the sand beds are lenticular, the potential yields of wells tapping the Wilcox can be expected to range over fairly wide limits. Proven yields of wells tapping the Wilcox in Cass and Marion Counties range from about $200 \mathrm{gpm}$ in the outcrop areas to nearly 500 $\mathrm{gpm}$ in the subbasin at Atlanta. The Wilcox probably would yield $500 \mathrm{gpm}$ or more of fresh water to wells in the subbasin at Avinger; and probably not more than $300 \mathrm{gpm}$ along the ridge from Douglassville to the Rodessa Fault near Jefferson. On the south side or downthrown side of the fault, a well at Jefferson yielded about $350 \mathrm{gpm}$ from the Wilcox.
The Carrizo Sand unconformably overlies the Wilcox Group. The full thickness of the Carrizo is variable in Cass and Marion Counties; it ranges from nearly 150 feet in the subbasins or local structural lows within the East Texas Embayment to about 50 feet or less elsewhere. Typically, the unit is composed of massive to crossbedded, coarse to fine sand. Locally, however, the sand is interbedded with silt and clay, so that in some places it is not easily distinguishable from the underlying Wilcox (well SX-35-11-203, Figure 11).

A firm estimate of potential well yields from the Carrizo in the report area cannot be made because the unit has been tapped mostly by wells with relatively small pump capacities. However, on the basis of production from Carrizo wells outside the report area, the Carrizo probably would yield $300 \mathrm{gpm}$ or more of fresh water to wells in the subbasins; elsewhere, probably considerably less.

\section{Reklaw Formation}

The Reklaw Formation conformably overlies the Carrizo Sand and crops out in narrow northeastwardtrending belts in the northern and southern parts of the report area (Figure 2). The outcrop of the Reklaw is expressed by a nearly level to gently rolling land surface, mantled by a red clayey to sandy soil containing limonite.

The Reklaw, which typically is a clay unit in much of the East Texas Embayment, exhibits considerable changes in composition and thickness in Cass and Marion Counties. In composition it varies from predominantly glauconitic clay to predominantly sand. Some lignite occurs in the formation. In thickness it varies from about $\mathbf{1 0 0}$ feet to $\mathbf{5 0}$ feet or less. In locations where the Reklaw is mostly sand, hydraulic continuity is enhanced between the units overlying and underlying the Reklaw. The dense clay character of the Reklaw as shown in well SX-35-20-203 (Figure 10) typifies the Reklaw as found southeastward in Gregg and Upshur Counties (Broom, 1969). In the vicinity of this well, the Reklaw tends to retard hydraulic continuity between the units.

The Reklaw yields small quantities of fresh water to domestic wells in Cass and Marion Counties.

\section{Queen City Sand}

The Queen City Sand has the most extensive outcrop area of any geologic unit in the report area (Figure 2). It has been completely removed by erosion 
only along the north edge of Cass County and in the southeastern segment of Marion County. Except for stream alluvium, the Queen City is overlain by scattered outliers of younger units in central parts of the report area. The outcrop of the Queen City is expressed by a hilly to moderately rolling land surface, mantled by a loose, gray to buff, sandy soil. Largely because of the scattered outliers of the overlying Weches Formation, which has caprock qualities, the Queen City has undergone differential erosion. The larger streams have created a relief of $\mathbf{2 0 0}$ feet or more in places on the Queen City outcrop.

The Queen City Sand, which attains a maximum thickness of about 400 feet, consists largely of massive to crossbedded fluvial sediments, locally stratified. It is composed generally of up to 80 percent medium to fine quartz sand, with small amounts of silt, clay, and lignite. The unit is tapped mostly for small domestic water supplies, but in some areas it probably would yield up to $200 \mathrm{gpm}$ or more of fresh water to wells.

\section{Weches Formation}

The Weches Formation overlies the Queen City Sand, and occurs mostly as scattered outliers (Figure 2) on the higher hills and ridges in Cass and Marion Counties. The formation consists principally of interbedded glauconite, glauconitic clay, and sand. The glauconite commonly weathers to limonitic concretions ("ironstone") at or near the surface, creating a resistant caprock. The limonite and other iron minerals are mined as iron ore. Generally, the Weches, which reaches a maximum thickness of about 60 feet, is not considered an aquifer, but locally it does yield small quantities of fresh water to shallow domestic wells.

\section{Sparta Sand}

The Sparta Sand, which overlies the Weches Greensand, occurs in Cass and Marion Counties mostly as erosional remnants (Figure 2) on the higher ridges and hills. These remnants of Sparta are usually composed of fine sand and sandy clay and seldom reach a thickness of more than $\mathbf{5 0}$ feet. Locally they yield small quantities of fresh water to domestic wells.

\section{Alluvium}

Alluvial sediments occur in and near the floodplains of Sulphur River and Big Cypress Bayou and their larger tributaries. The sediments consist of clay and silt, some fine sand, and minor amounts of gravel. They reach a maximum thickness of about 60 feet along Sulphur River, and about 25 feet along Big Cypress Bayou. The alluvium is not known to yield water to wells in the report area; doubtlessly, it would yield small quantities of fresh water if tapped by wells.

\section{Hydrological Designation of the Geologic Units}

The Wilcox Group, Carrizo Sand, and the Queen City Sand are the principal sources of ground water in Cass and Marion Counties. Locally the Reklaw Formation seems to be capable of yielding significant quantities of water. The four units are hydraulically connected throughout most of the area and function as a single aquifer. Therefore, in this report the four geologic units are considered as one hydrologic unit which has been named the Cypress aquifer. For the same reason, these four geologic units were considered as one hydrologic unit-the Cypress aquifer-in adjacent counties to the northwest and south (Broom and others, 1965; Broom and Myers, 1966).

The Weches Formation, Sparta Sand, and alluvium are comparatively unimportant as sources of ground water in the report area; therefore, the remainder of the report is devoted chiefly to the Cypress aquifer.

\section{GROUND-WATER HYDROLOGY}

\section{Occurrence and Movement of Ground Water}

Ground water in the Cypress aquifer occurs under both artesian and water-table conditions in Cass and Marion Counties. Generally in the report area, shallow wells or any wells that do not penetrate a confining layer of rock, tap water under water-table conditions, which occur mostly in the outcrop areas of the geologic units that compose the Cypress aquifer. Deep wells, or any wells that penetrate a confining layer of rock, generally tap water under artesian conditions, which occur mostly downdip from the outcrop of the geologic units that compose the Cypress aquifer.

Ground water generally moves slowly (tens to hundreds of feet per year) from areas of recharge to areas of discharge. The direction of movement of water in the Cypress aquifer is indicated by water-level contours in Figure 4. The regional slope (or direction of water movement) of the potentiometric surface is southeastward at about 5 feet per mile. However, significant cones of depression have been created by concentrated ground-water pumping in the vicinities of Bryans Mill, Atlanta, and that part of the Rodessa oil field in the southeastern corner of Cass County. Consequently, in these three areas of pumping, the direction of water movement is toward each cone of depression. In the Bryans Mill area, the cone of depression has approximately 75 feet of vertical closure; the hydraulic gradient across the 225-foot contour averages about 12 feet per mile. In the Atlanta area, the cone of depression has approximately 100 feet of vertical closure; the hydraulic gradient across the 150-foot contour averages about 27 feet per mile. In the Rodessa oil field area, the cone of depression has a 

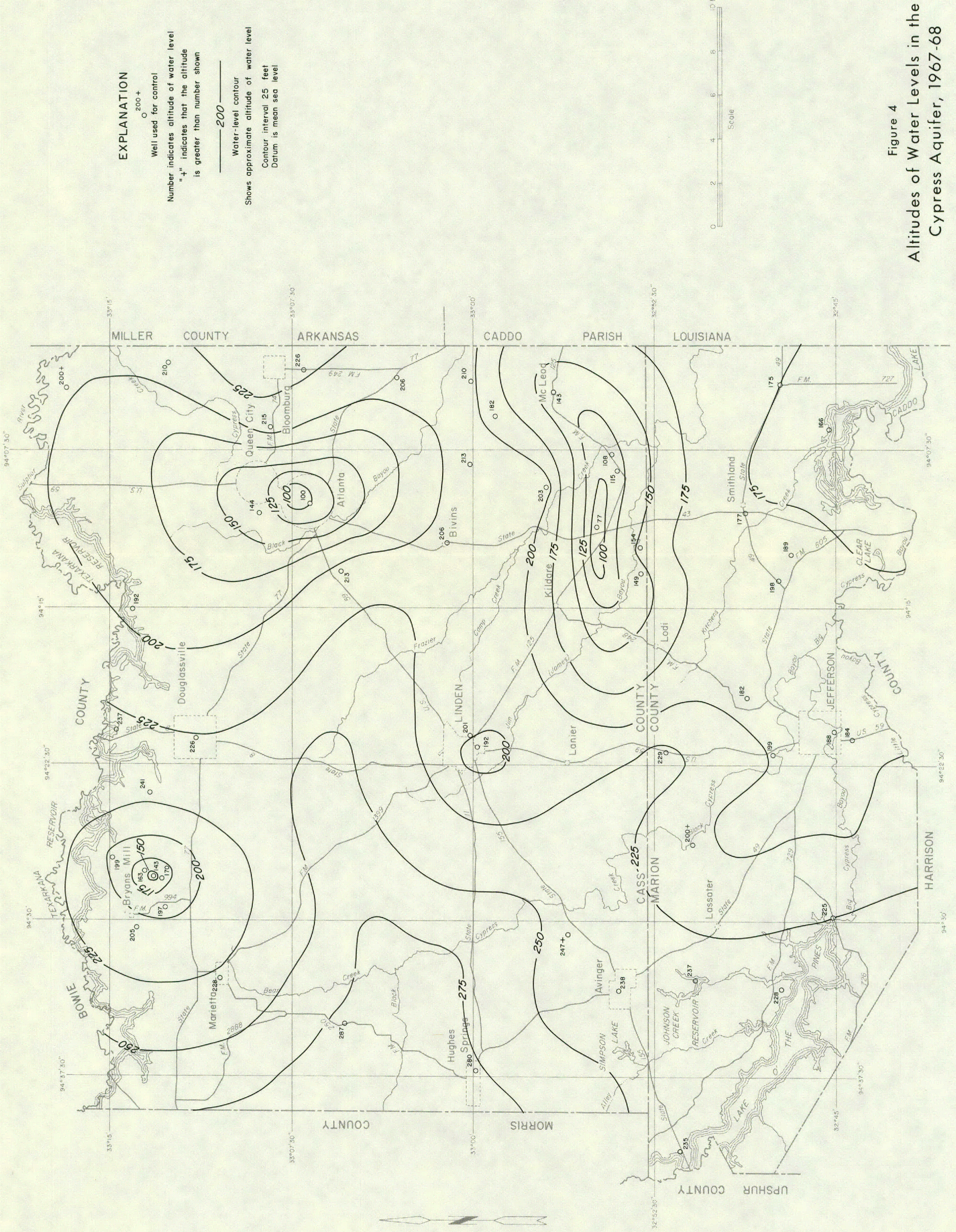

vertical closure of about 100 feet; the average hydraulic gradient across the 150 -foot contour is about 18 feet per mile.

With the exception of a slight cone of depression at Linden, there appears to be little alteration of the potentiometric surface by pumping in the southwestern and extreme southern parts of the report area.

\section{Recharge and Discharge}

Ground water in the Cypress aquifer is derived from the infiltration of precipitation on the outcrop areas of the geologic units composing the aquifer, from runoff enroute to water courses, and from the infiltration of water from streams and lakes. The recharge areas of the Cypress aquifer include all of the report area and adjacent areas to the north, west, and south. In addition, ground-water pumping around Atlanta and in that part of the Rodessa oil field in the southeast corner of Cass County results in subsurface recharge in these areas from adjoining areas in Arkansas and Louisiana.

The rate of natural recharge is governed by a number of factors, the most important of which are: (1) the type of soil in the outcrop areas; (2) the duration and intensity of rainfall; (3) the slope of the land surface; (4) vegetation; and (5) the depth to the water table. The total quantity of recharge to the Cypress aquifer could not be determined from the available data.

Discharge of water from the Cypress aquifer occurs under natural and artificial conditions. The natural discharge is the flow of springs and seeps, evaporation from the water table, and transpiration by trees and plants whose roots reach the water table. The quantity of water discharged by each of the natural processes is difficult to determine, but natural discharge from the Cypress aquifer is at least several times the amount artificially discharged by wells.

\section{Hydraulic Properties of the Cypress Aquifer}

The hydraulic properties of an aquifer that determine its capacity to transmit and store water are expressed as the transmissivity and the storage coefficient. (See section of report on definition of terms).

The results of nine aquifer tests are shown in Table 3. The transmissivities determined from these tests ranged from 200 to $14,000 \mathrm{gpd}$ per foot; discharge rates ranged from 37 to $475 \mathrm{gpm}$; and specific capacities ranged from 1.2 to $6.7 \mathrm{gpm}$ per foot of drawdown. The range in transmissivities is due to variations in the permeability and thickness of the aquifer. In most cases, the wells used for tests did not fully penetrate the aquifer; consequently, the results of the tests generally gave values that are less than those that would have been obtained from fully penetrating wells.

The hydraulic conductivities, which were estimated from the total thickness of sand believed to be contributing water to the well (in most of the wells it was the equivalent of the footage of screened or perforated intervals in the well), ranged from 5 to 180 gpd per square foot. and averaged about 65 gpd per square foot. Thus, where as much as $\mathbf{4 0 0}$ feet of sand is available in the aquifer, the transmissivity might be $26,000 \mathrm{gpd}$ per foot.

The storage coefficient obtained from one test was 0.00014 . This value is within the range generally attributable to artesian conditions. Although no tests were made in the water-table section of the aquifer, the storage coefficient for water-table conditions probably would be about 0.10 .

The transmissivity and storage coefficient may be used to predict future drawdowns of water levels by pumping. Figure 5 shows the relation of drawdown to distance and time as a result of pumping from a water-table aquifer of infinite areal extent. If the transmissivity and storage coefficient are 5,000 gpd per foot and 0.10 , respectively, which probably are representative of the water-table part of the Cypress aquifer, the decline in water level at a distance of 1,000 feet from a well pumping $300 \mathrm{gpm}$ would be 1 foot after 30 days, about 12 feet after one year, and about 27 feet after 10 years. If the transmissivity was smaller than that assumed, the drawndown would be greater.

Figure 6 shows similar relation as a result of pumping from an artesian aquifer of infinite areal extent with a transmissivity of 20,000 gpd per foot and a storage coefficient of 0.0001 . Under these conditions, the decline in water level at a distance of 1,000 feet from a well pumping at $500 \mathrm{gpm}$ would be 22 feet after 30 days, about 29 feet after one year, and about 35 feet after 10 years.

Pumping from wells too closely spaced may cause intersecting cones of depression, which will cause additional lowering of the water levels and serious declines in the yields of the wells. Figures 5 and 6 should serve as a general guide for the spacing of wells that tap the Cypress aquifer.

\section{USE AND DEVELOPMENT OF GROUND WATER}

Pumpage and use of ground water in Cass and Marion Counties in 1967 are summarized in Table 4. In that year, approximately $3.6 \mathrm{mgd}$ or 4,000 acre-feet was pumped from the Cypress aquifer for public supply, industrial use, and rural domestic and livestock purposes. No ground water was used for irrigation in 1967. 
Table 3.-Results of Aquifer Tests

\begin{tabular}{|c|c|c|c|c|c|c|}
\hline WELL & $\begin{array}{l}\text { SCREENED } \\
\text { INTERVAL } \\
\text { (FEET) }\end{array}$ & $\begin{array}{l}\text { AVERAGE } \\
\text { DISCHARGE } \\
\text { DURING TEST } \\
\text { (GPM) }\end{array}$ & $\begin{array}{l}\text { TRANS- } \\
\text { MISSIVITY } \\
\text { (GPD/FT) }\end{array}$ & $\begin{array}{l}\text { SPECIFIC } \\
\text { CAPACITY } \\
\text { (GPM/FT) }\end{array}$ & $\begin{array}{l}\text { STORAGE } \\
\text { COEFFICIENT }\end{array}$ & REMARKS \\
\hline DB-16-53-104 & $\begin{array}{l}257-267 \\
305-395\end{array}$ & 216 & 5,500 & 3.9 & - & Drawdown in pumped well. \\
\hline DB-16-55-801 & $670-720$ & 38.5 & 1,100 & 1.2 & - & Drawdown and recovery of pumped well. \\
\hline DB-16-62-702 & $\begin{array}{l}294-353 \\
378-400 \\
442-463 \\
500-522 \\
646-709\end{array}$ & 125 & 900 & 2.5 & - & Drawdown in pumped well. \\
\hline DB-16-63-301 & $660-829$ & 475 & 14,000 & - & - & Drawdown and recovery of pumped well. \\
\hline DB-16-64-201 & $\begin{array}{l}350-360 \\
375-395 \\
425-440\end{array}$ & 100 & 2,000 & 1.4 & - & $\begin{array}{l}\text { Recovery of pumped well. Data collected by } \\
\text { Layne-Texas Co. }\end{array}$ \\
\hline DB-35-04-803 & 271-321 & 37 & 2,300 & 1.2 & - & Drawdown and recovery of pumped well. \\
\hline DB-35-07-802 & $595-669$ & 230 & 8,700 & 6.7 & - & Drawdown in pumped well. \\
\hline$s \times-35-12-802$ & 232-272 & - & 200 & - & 0.00014 & $\begin{array}{l}\text { Drawdown in observation well. Well } \\
\text { SX-35-12-801 pumping } 23 \mathrm{gpm} \text {. }\end{array}$ \\
\hline sX-35-14-703 & 708-781 & 348 & 13,000 & 4.4 & - & Drawdown and recovery in pumped well. \\
\hline
\end{tabular}

Table 4.-Pumpage and Use of Ground Water in 1967

PUBLIC SUPPLY INDUSTRIAL SUPPLY RURAL DOMESTIC

AND LIVESTOCK

TOTAL

\begin{tabular}{|c|c|c|c|c|c|c|c|c|c|c|}
\hline \multirow{2}{*}{ COUNTY } & \multirow[b]{2}{*}{ MGD } & \multirow[b]{2}{*}{ ACRE-FEET } & \multicolumn{2}{|c|}{ COOLING AND PROCESS } & \multicolumn{2}{|c|}{ REPRESSURIZATION } & \multicolumn{2}{|c|}{ AND LIVESTOCK } & \multirow[b]{2}{*}{ MGD } & \multirow[b]{2}{*}{ ACRE-FEET } \\
\hline & & & MGD & ACRE-FEET & $\frac{\text { KLI }}{\text { MGD }}$ & ACRE-FEET & MGD & ACRE-FEET & & \\
\hline Cass & 1.04 & 1,166 & 0.47 & 527 & 1.25 & 1,401 & 0.40 & 448 & 3.16 & 3,542 \\
\hline Marion & .03 & 34 & .05 & 56 & .21 & 235 & .10 & 112 & .39 & 437 \\
\hline Total & 1.07 & 1,200 & 0.52 & 583 & 1.46 & 1,636 & 0.50 & 560 & 3.55 & 3,979 \\
\hline
\end{tabular}

Numbers should not be considered accurate to more than two significant figures. 


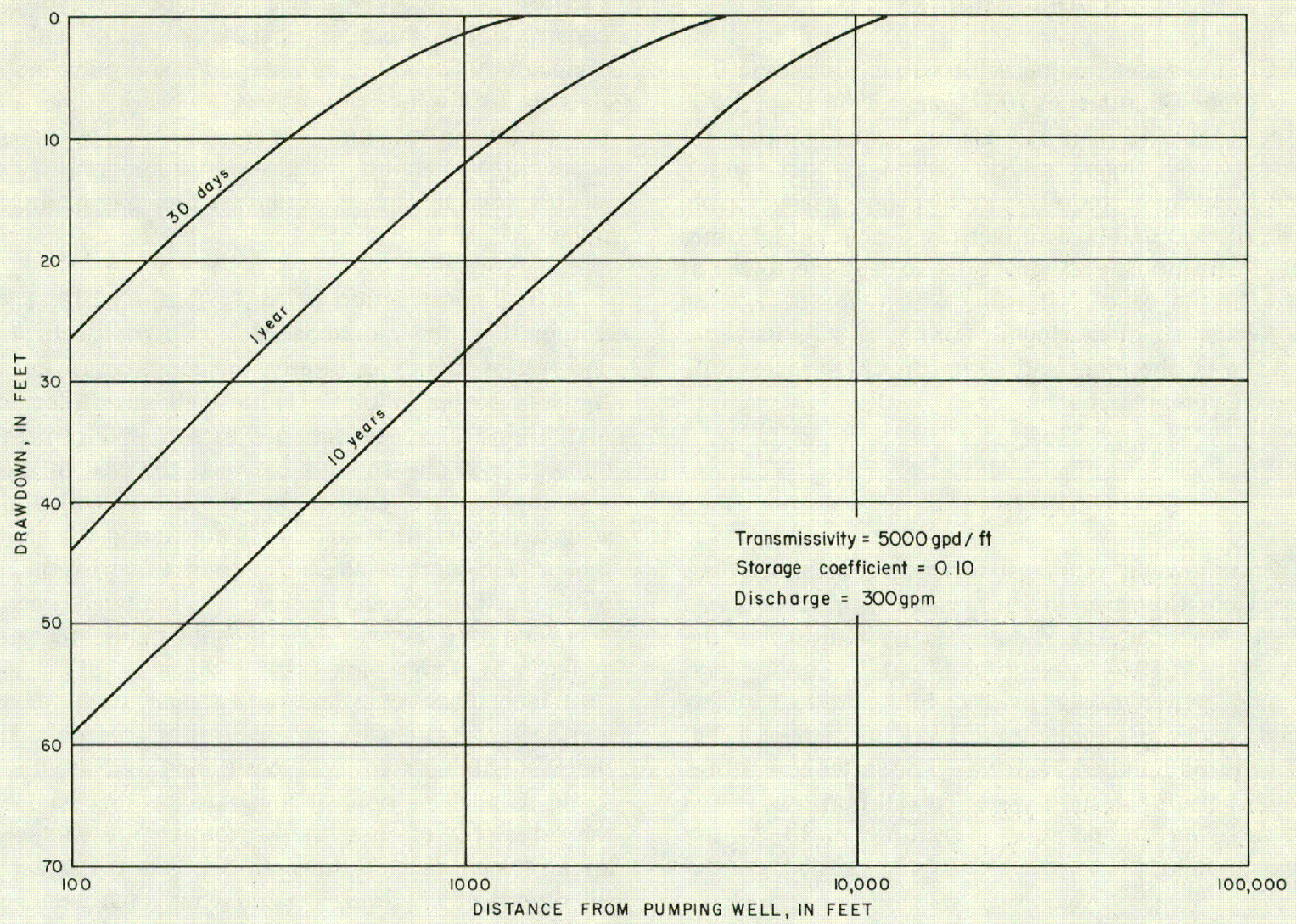

Figure 5.-Relation of Drawdown to Distance and Time, Water-Table Conditions

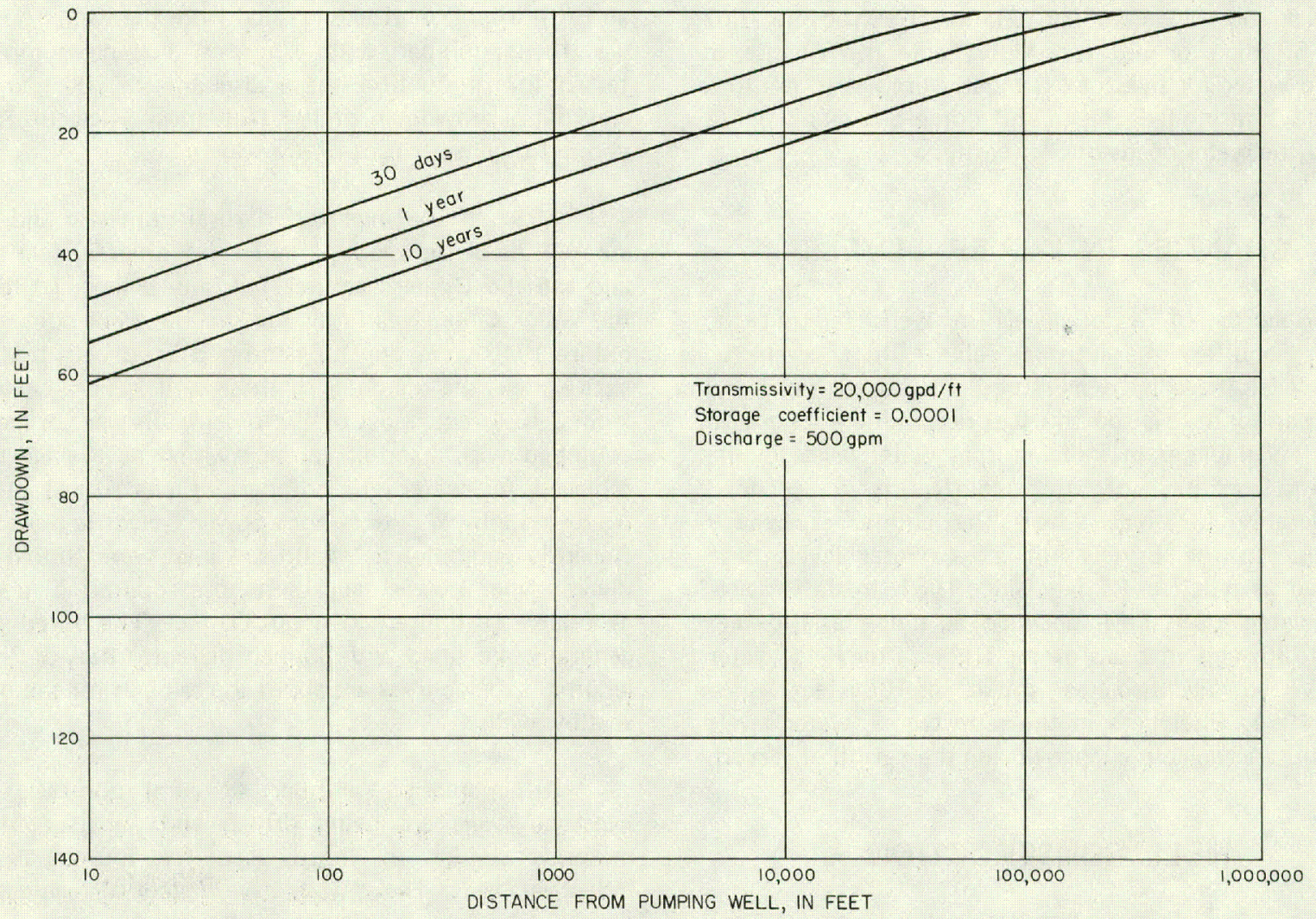

Figure 6.-Relation of Drawdown to Distance and Time, Artesian Conditions 


\section{Public Supply}

Ground-water pumpage for public supplies in Cass and Marion Counties in 1967 was 1.1 mgd or 1,200 acre-feet (Table 4). This includes municipal pumpage for Atlanta $(0.68 \mathrm{mgd}$ or 760 acre-feet per year), Linden $(0.13 \mathrm{mgd}$ or 150 acre-feet per year), Queen City (0.10 mgd or 110 acre-feet per year), and all other towns, institutions, and park sites except the towns of Hughes Springs and Jefferson, which are now using surface-water supplies. Hughes Springs obtains its water from Lake O' the Pines and Jefferson obtains its supply from Big Cypress Bayou.

\section{Industrial Use}

Ground-water pumpage for industrial use in Cass and Marion Counties in 1967 was 2.0 mgd or 2,200 acre-feet. Practically all water used by industry in the report area in 1967 was ground water. Cooling and processing required $0.52 \mathrm{mgd}$ or 580 acre-feet to be pumped; and waterflooding required $1.5 \mathrm{mgd}$ or 1,600 acre-feet to be pumped (Table 4). The latter constitutes the largest use of ground water for all purposes in the report area, and the pumping is confined mostly to the Rodessa oil field.

\section{Rural Domestic and Livestock Uses}

Ground-water pumpage for rural domestic and livestock uses in Cass and Marion Counties in 1967 was $0.50 \mathrm{mgd}$ or 560 acre-feet (Table 4). The use of ground water for livestock is mostly limited to poultry; generally, spring-fed creeks and numerous stock ponds supply the water needs of beef cattle.

\section{CHANGES IN WATER LEVELS}

Records of water "levels in wells tapping the Cypress aquifer are given in Table 7. In general, the water levels have been measured too infrequently and for a period that is too short to determine a long-term trend. Available data indicate that water levels in the artesian section of the aquifer have declined considerably in areas where the aquifer is heavily pumped. In the Bryans Mill area, water levels have declined as much as 86 feet since 1961. In the Atlanta area, water levels have declined as much as 100 feet since 1936, and in parts of the Rodessa oil field, water levels have declined as much as 109 feet since about 1964. Elsewhere in the report area, water levels show no appreciable change during the period of record.

\section{WELL CONSTRUCTION}

The yields from wells tapping the Cypress aquifer in Cass and Marion Counties depend on the well location, well spacing, and the method and type of well construction. Improper spacing of wells will cause unnecessary increases in water lifts and pumping costs. Because of the non-uniform water-bearing character of the aquifer, in localities where large yields are needed, it is advisable to choose a well site based on sand sampling, electric logging, and pumping tests of one or more test holes.

The construction of well DB-16-63-202 (Table 7) is typical of the municipal and industrial wells in Cass and Marion Counties. Briefly, the construction details of the well are as follows: (1) the well was drilled to 564 feet, 14-inch surface casing was set, and cement was pumped into the annulus between the wall of the well and the surface casing-the cement provided a seal against downward leakage of water along the casing to the producing zone and a deterrent to corrosion of the outer surface of the casing; (2) the well was then deepened to 670 feet; (3) the hole below the surface casing was underreamed to a diameter of 30 inches; (4) 8-inch blank steel liner and screen, with set nipple and back pressure valve on the bottom, was lowered into the well-the screen was positioned on the material string so as to be opposit the water-bearing sands when the set nipple reached the bottom of the well; (5) the underreamed part of the well, opposite the screen, was filled with small gravel, forming what is termed a "gravel pack" (the gravel allows larger screen openings to be used which reduces the velocity of water entering the well, thereby reducing the amount of fine sand that otherwise would enter the well and be pumped from it); and (6) drilling mud was washed from the well. The well was then equipped with a vertical turbine pump and tested for production. At a discharge of $300 \mathrm{gpm}$ the well had a drawdown of 191 feet-a specific capacity of about $1.6 \mathrm{gpm}$ per foot of drawdown.

Most of the inventoried rural domestic and livestock wells in the report area are less than 50 feet deep and tap the Cypress aquifer for only a few feet below the water table. Nearly all the shallow wells completed before 1940 were dug by hand and lined with brick or native rock; the diameter of these wells generally ranges from 3 to 4 feet. Most of the older wells were originally equipped with hand-lift pumps which have since been replaced by water-jet, cylinder, or centrifugal pumps powered by $1 / 4$ - to $3 / 4$-horsepower electric motors. Recently completed shallow wells were bored by bucket-type power augers whose operating depths generally are limited to about 50 feet. The bored wells generally are lined with 30-inch diameter tiles of 3-foot lengths. Lift facilities are about the same as for the other shallow wells.

An increasing number of rural domestic and livestock wells are being drilled and constructed by methods similar to those used for municipal and industrial wells. These wells have a steel surface casing, usually 4 inches in diameter, set at the top of the water-bearing sand and the annulus between the wall of 
the hole and the surface casing is filled with cement. A 2- to 3-inch diameter screen or perforated liner is set opposite the water sand. A gravel- or sand-pack is sometimes used. The drilled rural domestic and livestock wells are usually equipped with water-jet or submergible turbine pumps, powered by electric motors of about 1 horsepower.

\section{CHEMICAL QUALITY OF GROUND WATER}

The major factors that determine the suitability of a water supply are the limitations imposed by the comtemplated use of the water. Among the various criteria established for water quality are: bacterial content; physical characteristics such as temperature, odor, color, and turbidity; and chemical constituents. Usually, the bacterial content and the undersirable physical properties can be alleviated economically, but the removal of undesirable chemical constituents can be difficult and expensive. The source and significance of dissolved-mineral constituents are summarized in Table 5

Chemical analyses of water from 104 wells and one spring in the Cypress aquifer are shown in Table 9. Table 9 also contains one analysis of water from a flowing well (DB-16-60-101, Figure 9) that reportedly taps the Woodbine Formation at a depth of 3,000 or more feet below the Cypress aquifer.

\section{Water-Quality Requirements}

\section{Public Supply}

The U.S. Public Health Service (1962) has established, and periodically revises, standards of drinking water to be used on common carriers engaged in interstate commerce. The standards are designed to protect the traveling public and commonly are used to evaluate domestic and public water supplies. According to the standards, chemical constituents should not be present in a public water supply in excess of the listed concentrations of common constituents shown in the following table, except where other more suitable supplies are not available. Below is a partial list of the standards adopted by the U.S. Public Health Service $(1962$, p. $7-8)$; these constituents are included in the table of chemical analyses (Table 9 ).

$\begin{array}{lc}\text { SUBSTANCE } & \begin{array}{c}\text { CONCENTRATION } \\ \text { (MG/L) }\end{array} \\ \text { Chloride }(\mathrm{CI}) & 250 \\ \text { Fluoride }(\mathrm{F}) & 1.0^{*} \\ \text { Iron }(\mathrm{Fe}) & 0.3 \\ \text { Nitrate }\left(\mathrm{NO}_{3}\right) & 45\end{array}$

$\begin{array}{lc}\text { SUBSTANCE } & \begin{array}{c}\text { CONCENTRATION } \\ \text { (MG/L) }\end{array} \\ \text { Sulfate }\left(\mathrm{SO}_{4}\right) & 250 \\ \text { Dissolved solids } & 500\end{array}$

* Based on the annual average of maximum daily air temperatures of $77^{\circ} \mathrm{F}\left(25^{\circ} \mathrm{C}\right)$ at Marshall $(15$ miles south of Jefferson) from 1910 to 1968 . The minimum desirable concentration is $0.7 \mathrm{mg} / \mathrm{l}$.

\section{Industrial Use}

The quality of water suitable for industrial use does not necessarily depend on potability-it may or may not be acceptable for human consumption. Suggested water-quality tolerances for a number of industries have been summarized by Hem (1959, p. 250-254) and Moore (1940). Water used by industry is commonly classified by uses as cooling, boiler, and process waters. For cooling uses the natural water temperature may be significant. Any constituent of the water that may adversely affect the heat-exchange surfaces is undesirable for cooling uses. Calcium, magnesium, aluminum, iron, and silica may cause scale or incrustations in both cooling and boiler facilities. The scale-forming tendency of silica in boiler water increases with applied pressures. The maximum suggested concentrations of silica in boiler water (Moore, 1940) for various ranges of boiler pressure, are shown as follows:

$\begin{array}{rc}\begin{array}{c}\text { CONCENTRATION OF } \\ \text { SILICA (MG/L) }\end{array} & \begin{array}{c}\text { BOILER PRESSURE } \\ \text { (PSI) }\end{array} \\ 20 & \begin{array}{c}\text { Less than } 150 \\ 20\end{array} \\ 5 & 150-250 \\ 1 & 251-400 \\ & \text { Mare than } 400\end{array}$

Process water, the water incorporated into or used in contact with the manufactured products, is subject to a wide range of quality requirements. The quality requirements for this use may include physical and biological factors in addition to chemical factors. Many process waters must be low in dissolved solids and free of iron and manganese. Unlike cooling and boiler water, much of the process water is consumed or undergoes a change during the manufacturing process and subsequently is either not available or not suitable for reuse.

\section{Irrigation}

The suitability of water for irrigation generally cannot be evaluated on chemical content alone; the evaluation also should consider the type of soil, adequacy of drainage, tolerance of crops, and frequency 
CONSTITUENT

OR

PROPERTY

Silica $\left(\mathrm{SiO}_{2}\right)$

Iron (Fe)

Calcium ( $\mathrm{Ca}$ ) and

magnesium $(\mathrm{Mg})$

Sodium ( $\mathrm{Na}$ ) and potassium (K)

Bicarbonate $\left(\mathrm{HCO}_{3}\right)$
and carbonate $\left(\mathrm{CO}_{3}\right)$

Sulfate $\left(\mathrm{SO}_{4}\right)$

Chloride (CI)

Fluoride (F)

Nitrate $\left(\mathrm{NO}_{3}\right)$

Dissolved solids

Hardness as $\mathrm{CaCO}_{3}$

Specific conductance

Hydrogen ion concentration $(\mathrm{pH})$
SOURCE OR CAUSE

Dissolved from practically all rocks and soils, commonly less than $30 \mathrm{mg} / \mathrm{l}$. High concentrations, as much as $100 \mathrm{mg} / \mathrm{l}$, generally occur in highly alkaline waters.

Dissolved from practically all rocks and soils. May also be derived from iron pipes, pumps, and other equipment. More than 1 or $2 \mathrm{mg} / \mathrm{l}$ of iron in surface waters generally indicates acid wastes from mine drain acid other sources.

Dissolved from practically all soils and rocks, but especially from limestone, dolomite, and gypsum. Calcium and magnesium are found in large quantities in some found in large quantities in some
brines. Magnesium is present in large quantities in sea water.

Dissolved from practically all rocks and soils. Found also in ancient brines, sea water, industrial brines, and sewage.

Action of carbon dioxide in water on carbonate rocks such as limestone and dolomite.

Dissolved from rocks and soils Dissolved from rocks and soils
containing gypsum, iron sulfides, containing gypsum, iron sulfides, and other sulfur compounds. and in some industrial wastes.

Dissolved from rocks and soils. Present in sewage and found in large amounts in ancient brines, sea water, and industrial brines.

Dissolved in small to minute quantities from most rocks and soils. Added to many waters by fluoridation of municipal supplies.

Decaying organic matter, sewage, fertilizers, and nitrates in soil.

Chiefly mineral constituents dissolved from rocks and soils. solved from rocks and soils.
Includes some water of crystalli. zation.

In most waters nearly all the hardness is due to calcium and magnesium. All the metallic cations other than the alkali metals also cause hardness.

Mineral content of the water. Acids, acid-generating salts, and free carbon dioxide lower the $\mathrm{pH}$. Carbonates, bicarbonates, hydroxides, and phosphates,

\section{SIGNIFICANCE}

Forms hard scale in pipes and boilers. Carried over in steam of high pressure boilers to form deposits on blades of turbines. Inhibits deterioration of zeolite-type water softeners.

On exposure to air, iron in ground water oxidizes to reddish brown precipitate. More than about $0.3 \mathrm{mg} / \mathrm{s}$ stains laundry and utensils reddish-brown. Objectionable for food processing, tex tile processing, beverages, ice manufacture, brewing, and other processes. U.S. Public Health Service (1962) drinking-water standards state that iron should not exceed $0.3 \mathrm{mg} / \mathrm{l}$. Larger quantities cause unpleasant taste and favor growth of iron bacteria.

Cause most of the hardness and scale-forming properties of water: soap consuming (see hardness). Waters low in calcium and magnesium desired in electroplating, tanning, dyeing, and in textile manufacturing.

Large amounts, in combination with chloride, give a salty taste. Moderate quantities have little effect on the usefulness of water for most purposes. Sodium salts may cause foaming in steam boilers and a high sodium content may limit the use of water for irrigation.

Bicarbonate and carbonate produce alkalinity. Bicarbonates of calcium and magnesium decompose in steam boilers and hot water facilities to form scale and release corrosive carbon dioxide gas. In combination with calcium and magnesium, cause carbonate hardness.

Sulfate in water containing calcium forms hard scale in steam boilers. In large amounts, sulfate in combination with other ions bollers. In large amounts, sulfate in combination with other ions gives bitter taste to water. Some calcium sulfate is considered (1962) drinking-water standards recommend that the sulfate (1962) drinking-water standards recor

In large amounts in combination with sodium, gives salty taste to drinking water. In large quantities, increases the corrosiveness of water. U.S. Public Health Service (1962) drinking-water stan dards recommend that the chloride content should not exceed $250 \mathrm{mg} / \mathrm{l}$.

Fluoride in drinking water reduces the incidence of tooth decay when the water is consumed during the period of ename calcification. However, it may cause mottling of the teeth depending on the concentration of fluoride, the age of the child, amount of drinking water consumed, and susceptbility of the individual. (Maier, 1950)

Concentration much greater than the local average may suggest pollution. U.S. Public Health Service (1962) drinking-water standards suggest a limit of $45 \mathrm{mg} / \mathrm{l}$. Waters of high nitrate content have been reported to be the cause of methemoglobinemia (an often fatal disease in infants) and therefore should not be used in infant feeding. Nitrate has been shown to be helpful in reducing inter-crystalline cracking of boiler steel. It undesirable tastes and odors.

U.S. Public Health Service (1962) drinking-water standards recommend that waters containing more than $500 \mathrm{mg} / \mathrm{l}$ dissolved recommend that waters containing more than $500 \mathrm{mg} / \mathrm{l}$ dissolved Wolids not be used if other less mineralized supplies are available. unsuitable for many purposes.

Consumes soap before a lather will form. Deposits soap curd on bathtubs. Hard water forms scale in boilers, water heaters, and pipes. Hardness equivalent to the bicarbonate and carbonate is called carbonate hardness. Any hardness in excess of this is called non-carbonate hardness. Waters of hardness as much as 60 $\mathrm{ppm}$ are considered soft; 61 to $120 \mathrm{mg} / \mathrm{l}$, moderately hard; 121 to $180 \mathrm{mg} / \mathrm{I}$, hard; more than $180 \mathrm{mg} / \mathrm{l}$, very hard.

Indicates degree of mineralization. Specific conductance is a measure of the capacity of the water to conduct an electric current. Varies with concentration and degree of ionization of the constituents.

A pH of 7.0 indicates neutrality of a solution. Values higher than 7.0 denote increasing alkalinity: values lower than 7.0 indicate increasing acidity. pH is a measure of the activity of the decreasing $\mathrm{pH}$. However, excessively alkaline waters may also attack metals. 
of rainfall. Generally, water may be used safely for supplemental irrigation if its conductivity (an index of the salinity hazard) is less than 2,250 micromhos per centimeter at $25^{\circ} \mathrm{C}$ and its SAR (sodium-adsorption ratio) is less than 14 (Wilcox, 1955, p. 15). High SAR of water causes soil, especially fine-textured soil, to become "tight".

Another factor used in assessing the quality of water for irrigation is the RSC (residual sodium carbonate). Excessive RSC will cause water to be alkaline, and the organic content of the soil will tend to dissolve. Wilcox $(1955$, p. 11) states that water containing more than $2.5 \mathrm{me} / \mathrm{l}$ (milliequivalents per liter) RSC is not suitable for irrigation. The degree of leaching, however, will modify the permissible limit to some extent (Wilcox, Blair, and Bower, 1954, p. 265).

\section{Water Quality in the Cypress Aquifer}

Chloride concentrations in 109 samples of water from wells ranged from 1.5 to $985 \mathrm{mg} / \mathrm{l}$ (Figure 7). The highest concentrations of chlorides were found in wells tapping the basal section of the aquifer in the vicinity of the Rodessa Fault. Wells producing high-chloride water were generally more than 400 feet deep. Water from wells less than 400 feet deep in the faulted area generally did not have excessive concentrations of chloride. Chlorides were not excessive in water from the areas that included Atlanta, Linden, and Avinger.

Concentrations of chloride in excess of $250 \mathrm{mg} / \mathrm{l}$ were found in water from wells more than 300 feet deep in the area extending northeastward from Douglassville. Only the very shallow wells (50 feet or less) contained water with concentrations of chlorides in excess of 250 $\mathrm{mg} / \mathrm{l}$ in the Bryans Mill area. High concentrations of chloride in water from the shallow wells probably result from local natural circumstances rather than from pollution, because the analyses for those wells date back to 1941, before any significant industrial development. Elsewhere in the report area, all shallow segments of the aquifer yielded water very low in chloride content.

Fluoride concentrations in water samples from 70 wells ranged from 0.0 to $3.2 \mathrm{mg} / \mathrm{l}$. Water from 16 wells contained more than $1.0 \mathrm{mg} / \mathrm{l}$, and 50 contained less than the minimum desirable concentration of $0.7 \mathrm{mg} / \mathrm{l}$.

Iron concentrations in 34 samples of water from wells ranged from 0.02 to $11 \mathrm{mg} / \mathrm{l}$, and manganese in 2 water samples was 0.03 and $0.05 \mathrm{mg} / \mathrm{l}$. The highest concentrations of iron generally were found in water from wells tapping the aquifer at depths of 50 to 200 feet. This intermediate depth zone that generally yields water having high iron content is typical for all the Tertiary sediments in the northeast Texas area. If wells are so constructed and pumped as to avoid drawing water from this zone, excessive iron concentrations in well water can be avoided. If water high in iron is used, the iron can be reduced substantially by proper treatment.

Nitrate concentrations in 98 samples of water from wells ranged from 0.0 to $104 \mathrm{mg} / \mathrm{l}$. Only 5 samples had concentrations in excess of $45 \mathrm{mg} / \mathrm{l}$. Four of these samples were from wells less than $\mathbf{5 0}$ feet deep; the other sample was from a well 158 feet deep. High nitrate concentrations are localized and occur mostly in the very shallow parts of the aquifer, especially in the vicinity of septic tanks, barnyards, and other sites of organic waste.

Sulfate concentrations are generally very low in water from the Cypress aquifer. In 101 samples of water from wells, only 2 samples had sulfate concentrations in excess of $250 \mathrm{mg} / \mathrm{l}$, and only 13 samples had concentrations greater than $20 \mathrm{mg} / \mathrm{l}$. The highest concentration, $352 \mathrm{mg} / \mathrm{l}$, was in well SX-35-12-701, which is used for public drinking water at a recreation site on Lake $O^{\prime}$ the Pines.

Dissolved-solids content in 99 samples of water from wells ranged from 12 to $2,119 \mathrm{mg} / \mathrm{l}$. The variation of dissolved-solids concentrations, geographically and with depth, generally follows that of chloride concentrations (Figure 7). In wells more than about 400 feet deep in the vicinity of the Rodessa Fault, dissolved solids generally range from $500 \mathrm{mg} / \mathrm{l}$ to more than $1,000 \mathrm{mg} / \mathrm{l}$. In the central part of the report area that includes Atlanta, Linden, and Avinger, wells tapping the basal part of the aquifer produce water containing about 500 $\mathrm{mg} / \mathrm{l}$ dissolved solids but not exceeding 1,000 mg/l. In the area extending northeastward from Douglassville, wells deeper than about 300 feet yield water containing about $1,000 \mathrm{mg} / \mathrm{l}$ dissolved solids. The deeper wells (about 300 to 400 feet) in the Bryans Mill area yield water having less than $500 \mathrm{mg} / \mathrm{l}$ dissolved solids, but the very shallow wells ( 50 feet or less in the Bryans Mill area yield water having concentrations of dissolved solids from 600 to $900 \mathrm{mg} / \mathrm{l}$. Elsewhere in Cass and Marion Counties, water from shallow wells seldom has concentrations of more than $200 \mathrm{mg} / \mathrm{l}$ dissolved solids.

Hardness in 108 samples of water from wells ranged from 1 to $803 \mathrm{mg} / \mathrm{l}$. Only 12 of the samples from the Cypress aquifer had hardness greater than $60 \mathrm{mg} / \mathrm{l}$, and of those 12, most of the water came from wells less than 50 feet deep. Water in the Cypress aquifer is generally soft.

Silica concentrations in 48 samples of water from wells ranged from 6.6 to $88 \mathrm{mg} / \mathrm{l}$, but only two samples had more than $40 \mathrm{mg} / \mathrm{l}$. In general, concentrations of silica tended to be less in samples from deep wells.

The $\mathrm{pH}$ of 55 samples of water from wells ranged from 3.4 to 8.5. Practically all samples having a $\mathrm{pH}$ of 7.0 or less acid were from wells less than 200 feet 
deep, whereas samples showing a $\mathrm{pH}$ of more than 7.0 were from wells more than 200 feet deep. This generally places the position of neutral water about at the base of the intermediate-depth zone, which is high in iron. Thus waters above depths of 200 feet are generally more corrosive with respect to $\mathrm{pH}$ in addition to being high in iron.

Temperatures of water from the Cypress aquifer range from $18^{\circ} \mathrm{C}\left(64^{\circ}-65^{\circ} \mathrm{F}\right)$ to $26^{\circ} \mathrm{C}\left(78^{\circ}-79^{\circ} \mathrm{F}\right)$, gradually increasing with depth. The temperature increases about $0.5^{\circ} \mathrm{C}\left(1^{\circ} \mathrm{F}\right)$ per 100 feet in depth.

The specific conductance (conductivity) of 54 samples of water from wells ranged from 34 to 2,990 micromhos, and was less than 2,250 micromhos in all but 2 samples. The SAR values of water from 44 samples ranged from 0.1 to 75 and was less than 14 in half of the samples.

The RSC values of 52 samples of water from wells ranged from 0.00 to $10.9 \mathrm{me} / \mathrm{I}$ and exceeded $2.5 \mathrm{me} / \mathrm{l}$ in 67 percent of the samples. Most of the high RSC values were from wells several hundred feet deep.

The boron content of water does not seem to be a problem. Two determinations of boron from water in the report area and 22 determinations in Harrison County (Broom and Myers, 1966, p. 32), where hydrologic conditions are similar to those in the report area, showed that boron did not exceed $1.0 \mathrm{mg} / \mathrm{l}-$ the permissible limit for irrigating boron-sensitive crops (Wilcox, 1955, p. 11).

On the basis of SAR and RSC, much of the water would be considered undesirable for irrigation; however, because of the high rainfall, sandy soil, and well-drained land surfaces in Cass and Marion Counties, most of the water from the Cypress aquifer probably could be used safely for supplemental irrigation without serious detriment to the soils.

To provide information on the presence and extent of pesticidal contamination of ground water, pesticide analyses were made on five samples of ground water. The water was analyzed for nine insecticides and three herbicides recommended for monitoring by the Subcommittee on Pesticide Monitoring of the Federal Committee on Pest Control (Green and Love, 1967, p. 13-16). Samples of water were collected on July 13, 1968, from wells DB-16-47-501, DB-16-54-202, SX-35-12-402, SX-35-12-701, and SX-35-13-703, which ranged in depth from 46 to 115 feet (See Figure 9 for locations of the wells). The analyses indicated that no pesticides were present in the water sampled.

\section{DISPOSAL OF OIL-FIELD BRINES}

Considerable quantities of brine are produced with oil in Cass and Marion Counties. According to preliminary unpublished figures of a brine inventory in the two counties by the Texas Railroad Commission, brine production in 1967 was 2,606,222 barrels (about 336 acre-feet). Table 6 shows the amount of brine production reported in each field in 1967 and the methods of disposal. Figure 9 shows the location of the oil and gas fields. Without adequate disposal methods, brine may contaminate potable water supplies in the report area.

Methods of brine disposal are regulated by the Texas Railroad Commission. Rules require that oil-field brine be disposed of in such a way that surface- or ground-water sources are not contaminated. Of the brine produced in the report area, 90 percent was disposed of by injection wells and 10 percent was disposed of in open pits. Effective January 1, 1969, the Texas Railroad Commission prohibited the use of pits for storage and evaporation of oil-field brine and certain other mineralized waters (by Special Order No. 20-56, 841, amending Rule 8 of the General Conservation Rules of Statewide Application, State of Texas) except as may be approved by special Railroad Commission hearing.

Another potential source of contamination of ground-water supplies is brine that moves upward from deep strata through inadequately cased or improperly plugged oil and gas tests and wells. This contamination hazard has been minimized in many oil and gas fields by the regulations of the Railroad Commission, which specify in field rules the casing and plugging requirements. The field rules applying to surface-casing requirements in oil and gas fields in Cass and Marion Counties are sufficient to protect the Cypress aquifer.

\section{AVAILABILITY OF GROUND WATER FOR FUTURE DEVELOPMENT}

The availability of ground water for future development from the Cypress aquifer in Cass and Marion Counties depends principally on the capacity of the aquifer to transmit and store water and the rate of recharge to the aquifer. Another factor is the chemical quality of the water, which in some parts of the area may be a deterrent to development of the ground-water supplies, particularly for municipal and domestic uses.

The capacity of the Cypress aquifer to transmit water under the original hydraulic gradient that had not been significantly affected by pumping is a conservative indication of the rate of recharge and of the quantity of water that perennially would be available for development. On the basis of the present regional hydraulic gradient of about 5 feet per mile and an average transmissivity of 26,000 gpd per foot, about $8.5 \mathrm{mgd}$ (about 9,500 acre-feet per year) currently passes through a vertical section of the Cypress aquifer 65 miles long and coincident with the 225-foot water-level contour (Figure 4). 


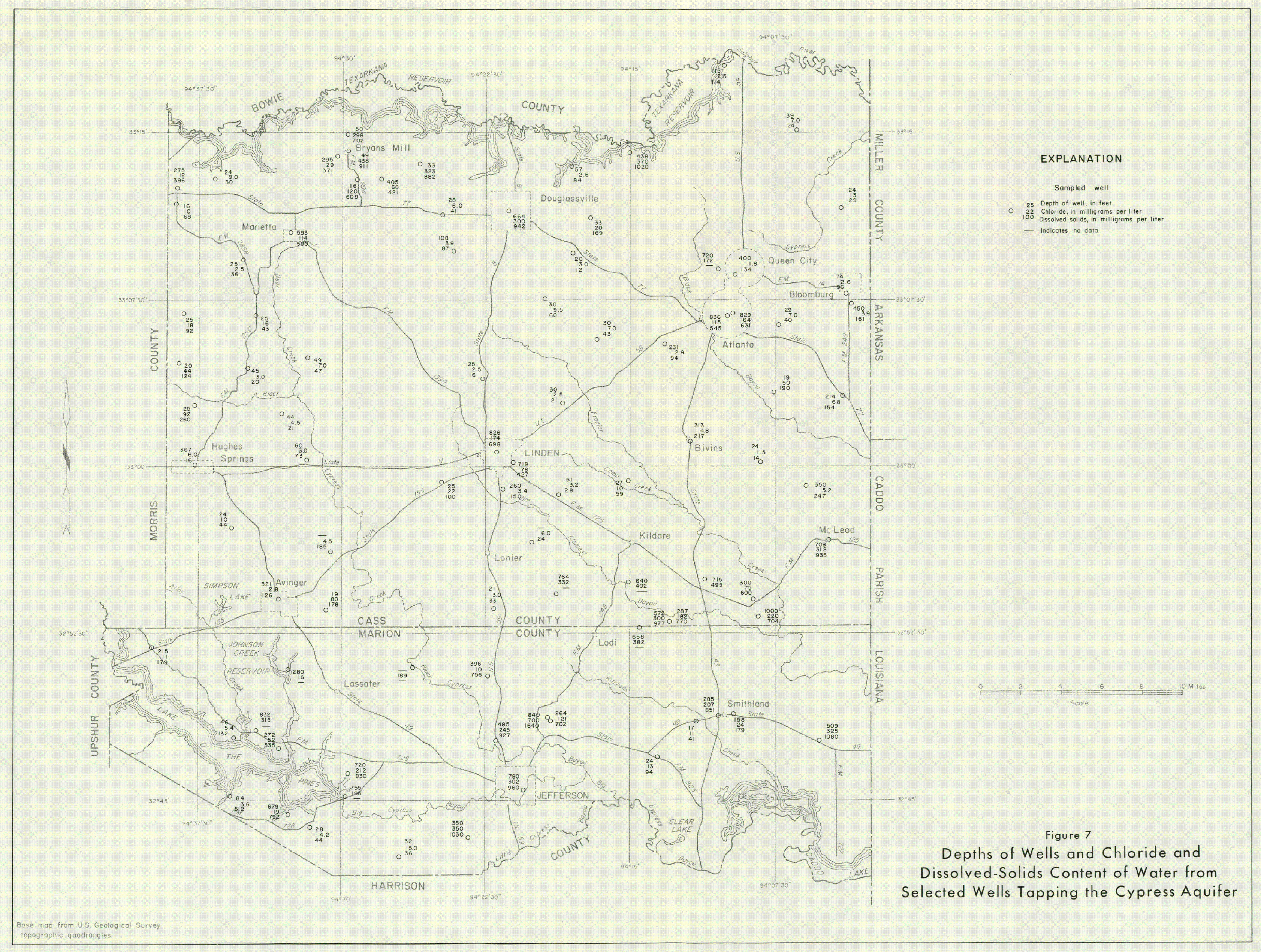



Table 6.-Oil- and Gas-Field Brine Production and Disposal, 1967

\begin{tabular}{|c|c|c|c|c|c|}
\hline \multirow{3}{*}{ FIELD NAME } & \multirow{3}{*}{$\begin{array}{l}\text { BRINE } \\
\text { PRODUCTION } \\
\text { (BARRELS) }\end{array}$} & \multicolumn{4}{|c|}{ BRINE DISPOSAL } \\
\hline & & \multicolumn{2}{|c|}{ INJECTION WELL } & \multicolumn{2}{|c|}{ OPEN-SURFACE PITS } \\
\hline & & BARRELS & PERCENT & BARRELS & PERCENT \\
\hline Bryans Mill & 16,500 & 16,500 & 100 & 0 & 0 \\
\hline Clinton Lake & 350 & 0 & 0 & 350 & 100 \\
\hline Excelsior & 11,434 & 0 & 0 & 11,434 & 100 \\
\hline Friendship & 215,190 & 213,000 & 99 & 2,190 & 1 \\
\hline Frost & 8,471 & 7,208 & 85 & 1,263 & 15 \\
\hline Green Fox & 15,330 & 15,330 & 100 & 0 & 0 \\
\hline Haynes & $1,218,409$ & $1,214,874$ & 99.5 & 3,535 & .5 \\
\hline Kildare & 784,027 & 766,000 & 96.5 & 18,027 & 3.5 \\
\hline Lake Ferrell & 20,834 & 20,834 & 100 & 0 & 0 \\
\hline Linden East & 5,110 & 5,110 & 100 & 0 & 0 \\
\hline Marion County (Shallow) & 11,132 & 0 & 0 & 11,132 & 100 \\
\hline Rodessa & 167,706 & 2,670 & 1 & 165,036 & 99 \\
\hline Skeeters & 182 & 0 & 0 & 182 & 100 \\
\hline Vickie Lynne & 123,250 & 91,250 & 74 & 32,000 & 26 \\
\hline Woodlawn & 8,297 & 1,100 & 13 & 7,197 & 87 \\
\hline Totals & $2,606,222$ & $2,353,876$ & 90 & 252,346 & 10 \\
\hline
\end{tabular}

Because the water levels in some wells have declined substantially over a period of several years and apparently are still declining, it is evident that the Cypress aquifer in Cass and Marion Counties has been affected by pumping. Data are not available to determine the undisturbed or original hydraulic gradient, and because the hydraulic gradient used in the calculation is believed to be slightly more than the original gradient, a conservative quantity of water that would be available perennially for development is probably somewhat less than $8.5 \mathrm{mgd}$.

Streamflow records for the report area are not sufficient to permit a determination of base flow of the streams, which would be an indication of potential recharge rejected as streamflow. However, based on studies in adjoining Harrison County (Broom and Myers, 1966) where hydrologic conditions are similar to those in Cass and Marion Counties, the quantity of water being discharged to the streams as rejected recharge is significant-probably equal to or greater than the 8.5 mgd being transmitted through the aquifer under the present gradient. Thus, considering the somewhat less than $8.5 \mathrm{mgd}$ that was probably originally moving through the aquifer and about an equal amount of water that is rejected as streamflow, about 17 mgd of ground water is perennially available for development. Considering the $3.6 \mathrm{mgd}$ of ground water that was used for all purposes in 1967, this pumpage probably could be increased slightly more than 4 times without exceeding the rate of replenishment and depeleting the supply.

The quantity of ground water that may be perennially available for development is small compared to the quantity of water that is in transient storage. Computations based on the saturated sand thickness (Figure 8) and a porosity factor of 30 percent indicate that approximately 90 million acre-feet of water is in transient storage, of which probably 50 million acre-feet is above 400-foot depths, which is an assumed limit for economically pumping water for most purposes. Of the 50 million acre-feet, only about half is recoverable by wells, and because of the low transmissibility of the aquifer, many small-capacity wells would be required to recover this quantity from storage.

The chemical quality of water, particularly the chloride content, may limit development of the ground water in places in the southern part of the area and locally in the northern part. The chloride concentration commonly is too high for municipal and rural domestic 
use in these areas. Likewise, high iron concentrations in the upper part of the aquifer is a limiting chemical factor. In most of the area, however, supplies of good quality water suitable for public supply, irrigation, and many industrial purposes are available for development.

The map showing the thickness of saturated sand in the Cypress aquifer (Figure 8) is useful in locating areas favorable for the development of large quantities of ground water in Cass and Marion Counties. The thickness of saturated sand ranges from about 100 feet in the northwestern and southeastern parts of the area to about 600 feet in the Avinger area. Generally, the most favorable areas for devleopment are those where the saturated sands are more than $\mathbf{4 0 0}$ feet thick, such as the Atlanta-Bloomburg area and the large area that includes Hughes Springs and Avinger. In these areas, properly constructed and adequately spaced wells probably would be capable of yielding $500 \mathrm{gpm}$ or more. Yields of this magnitude have been proven only in the Atlanta area. Similar yields probably could be obtained in the Avinger area where saturated sands reach a total thickness of slightly more than 600 feet.

\section{RECOMMENDATIONS FOR A CONTINUING OBSERVATION PROGRAM}

In order to keep abreast of changes in water levels and water quality, a continuing program of water-level measurement and ground-water sampling for chemical analysis is needed.

Approximately 20 wells are recommended for periodic water-level measurements. They should be concentrated especially in the Atlanta, Bryans Mill, Rodessa Fault, and Linden areas, in order to monitor future changes in the cones of depression in these areas.

About 10 wells are needed for periodic sampling for chemical analysis. These should be located in areas where water-quality problems exist, such as near the Rodessa Fault and in the area northeast of Douglassville. Some wells near the oil fields shown on Figure 9 should also be monitored for possible salt-water contamination. 




\section{DEFINITION OF TERMS}

Many of the following definitions have been taken or adapted from Meinzer (1923). American Geological Institute (1960), Langbein and Iseri (1960), and Ferris and others (1962).

Acre-foot (ac-ft).-The volume of water required to cover one acre to a depth of 1 foot $(43,560$ cubic feet or 325,851 gallons).

Aquiclude.-A formation, group of formations, or part of a formation that is non-water bearing, or is sufficiently impermeable to severely restrict the transmission of water.

Aquifer.-A formation, group of formations, or part of a formation that is water bearing, or is sufficiently permeable to allow transmission of considerable quantities of water.

Aquifer test.-A pumping test from which the essential hydrologic properties of an aquifer may be determined, such as the storage coefficient, hydraulic conductivity, and transmissivity.

Artesian aquifer.-An aquifer that is confined both above and below by a relatively impermeable formation (aquiclude), and in which water is under pressure greater than atmospheric pressure. Consequently, the water rises in artesian wells to levels above the top of the aquifer and sometimes rises to levels above land surface (flows).

Cone of depression.-Depression of the water table or potentiometric surface caused by a discharging well; more or less the shape of an inverted cone.

Drawdown.-The difference between the static water level and the pumping water level in a well.

Evapotranspiration.-A combined term for evaporation and transpiration; the amount of water withdrawn from surface and ground storage by evaporation and plants.

Fresh water and saline water.-The terms as applied in this report are taken from a general classification based on dissolved-solids content by Winslow and Kister (1956); fresh, 0 to $1,000 \mathrm{mg} / \mathrm{l}$ (milligrams per liter); slightly saline, 1,000 to $3,000 \mathrm{mg} / \mathrm{l}$; moderately saline, 3,000 to $10,000 \mathrm{mg} / \mathrm{l}$; very saline, 10,000 to $35,000 \mathrm{mg} / \mathrm{l}$; and brine, more than $35,000 \mathrm{mg} / \mathrm{l}$.

Hydraulic conductivity.-A measure of the capacity of an aquifer to transmit water. The rate of flow in gallons per day through a cross section of 1 square foot under a hydraulic gradient of 1 foot per foot and at a temperature $16^{\circ} \mathrm{C}\left(60^{\circ} \mathrm{F}\right)$.
Hydraulic gradient.-The slope of the water table or potentiometric surface, usually expressed in feet per mile.

Milliequivalents per liter (me/I).-The concentration of chemical substances in terms of the reacting values of electrically charged particles or ions in solution.

Milligrams per liter (mg/l).-A unit for expressing the concentration of chemical constituents in solution. Milligrams per liter represents the weight of solute per unit volume of water. As commonly measured and used, milligrams of a substance per liter of water is numerically equivalent to parts per million, when concentrations are less than about $7,000 \mathrm{mg} / \mathrm{l}$.

Potentiometric surface.-An imaginary surface that everywhere concides with the static level of the water in an aquifer. The surface to which the water from a given aquifer will rise under its hydrostatic pressure or head.

Specific capacity.- The rate of yield of a well per unit of drawdown, usually expressed as gallons per minute per foot of drawdown.

Storage coefficient.-The volume of water that an aquifer releases from or takes into storage per unit surface area of the aquifer per unit change in the component of head normal to that surface.

Transmissivity.-The rate of flow of ground water in gallons per day through a vertical strip of the aquifer 1 foot wide extending through the vertical thickness of the aquifer at a hydraulic gradient of 1 foot per foot and at the prevailing temperature of the water.

Transmission capacity of an aquifer.-The quantity of water that can be transmitted through a given width of an aquifer at a given hydraulic gradient, usually expressed in acre-feet per year or million gallons per day (mgd).

Water table.-The upper surface of the saturated zone.

Water-table aquifer.-An aquifer that is unconfined; the upper surface of the saturated zone is under atmospheric pressure only and the water is free to rise or fall in response to the changes in the volume of water in storage. The depth to the static water level in a water-table well coincides with the depth to the water table.

Yield of a well.-The rate of discharge, usually expressed in gallons per minute (gpm). In this report, yields are classified as small, less than $50 \mathrm{gpm}$; moderate, 50 to $500 \mathrm{gpm}$; and large, more than 500 gpm. 


\section{REFERENCES CITED}

American Geological Institute, 1960, Glossary of geology and related sciences with supplement: Washington, Am. Geol. Inst., 395 p.

Baker, E. T., Jr., Long, A. T., Jr., Reeves, R. D., and Wood, L. A., 1963, Reconnaissance investigation of the ground-water resources of the Red River, Sulphur River, and Cypress Creek basins, Texas: Texas Water Comm. Bull. 6306, 127 p.

Broadhurst, W. L., and Breeding, S. D., 1943a, Water resources of Harrison County, Texas: Texas Board Water Engineers duplicated rept., 53 p.

1943b, Water resources of Marion County, Texas: Texas Board Water Engineers duplicated rept., 34 p.

Broom, M. E., 1969, Ground-water resources of Gregg and Upshur Counties, Texas: Texas Water Devel. Board Rept. 101, 76 p.

Broom, M. E., Alexander, W. H., Jr., and Myers, B. M., 1965, Ground-water resources of Camp, Franklin, Morris, and Titus Counties, Texas: Texas Water Comm. Bull. 6517, 153 p.

Broom, M. E., and Myers, B. N., 1966, Ground-water resources of Harrison County, Texas: Texas Water Devel. Board Rept. 27, 73 p.

Bureau of Economic Geology, 1964, Geologic atlas of Texas, Tyler sheet: Univ. Texas at Austin, Bureau Econ. Geology map.

1966, Geologic atlas of Texas, Texarkana sheet: Univ. Texas at Austin, Bureau Econ. Geology map.

Cooper, H. H., and Jacob, C. E., 1946, A generalized graphical method for evaluating formation constants and summarizing well-field history: Am. Geophys. Union Trans., v. 27, no. IV, p. 526-534.

Deussen, Alexander, 1914, Geology and underground waters of the southeastern part of the Texas Coastal Plain: U.S. Geol. Survey Water-Supply Paper $335,365 \mathrm{p}$.

Fenneman, N. M., 1938, Physiography of Eastern United States: New York, McGraw-Hill Book Co., 714 p.

Ferris, J. G., Knowles, D. B., Brown, R. H., and Stallman, R. W., 1962, Theory of aquifer tests: U.S. Geol. Survey Water-Supply Paper 1536-E, p. 69-172.

Follett, C. R., and White, W. N., 1942, Records of wells, drillers' logs, water analyses, and map showing locations of wells and springs in Cass County, Texas: Texas Board Water Engineers duplicated rept., 44 p.
Green, R. S., and Love, S. K., 1967, Network to monitor hydrologic environment covers major drainage rivers: Pesticides Monitoring Jour., v. 1, no. 1, p. 13-16.

Hem, J. D., 1959, Study and interpretation of the chemical characteristics of natural water: U.S. Geol. Survey Water-Supply Paper 1473, 269 p.

Kane, J. W., 1967, Monthly reservoir evaporation rates for Texas, 1940 through 1965: Texas Water Devel. Board Rept. 64, 111 p.

Langbein, W. B., and Iseri, K. T., 1960, General introduction and hydrologic definitions: U.S. Geol. Survey Water-Supply Paper 1541-A, 29 p.

Maier, F. J., 1950, Fluoridation of public water supplies: Am. Water Works Assoc. Jour., v. 42, pt. 1, p. $1120-1132$.

Meinzer, O. E., 1923, Outline of ground-water hydrology, with definitions: U.S. Geol. Survey Water-Supply Paper 494, 71 p.

Moore, E. W., 1940, Progress report of the committee on quality tolerances of water for industrial uses: New England Water Works Assoc. Jour., v. 54, p. 261-272.

Railroad Commission of Texas, 1966, Annual report of the Oil and Gas Division, 1965: Railroad Comm. of Texas, $562 \mathrm{p}$.

Sellards, E. H., and others, 1932, The geology of Texas, v. 1, stratigraphy: Univ. Texas Bull. 3232, 1,007 p.

Sundstrom, R. W., Hastings, W. W., and Broadhurst, W. L., 1948, Public water supplies in eastern Texas: U.S. Geol. Survey Water-Supply Paper 1047, 285 p.

U.S. Public Health Service, 1962, Public Health Service drinking water standards, Public Health Service Pub. 956, 61 p.

Wenzel, L. K., 1942, Methods for determining permeability of water-bearing materials with special reference to discharging-well methods: U.S. Geol. Survey Water-Supply Paper 887, 192 p.

Wilcox, L. V., 1955, Classification and use of irrigation waters: U.S. Dept. of Agr. Circ. 969, 19 p.

Wilcox, L. V., Blair, G. Y., and Bower, C. A., 1954, Effect of bicarbonate on suitability of water for irrigation: Soil Sci., v. 77, no. 4, p. 259-266.

Winslow, A. G., and Kister, L. R., Jr., 1956, Saline-water resources of Texas: U.S. Geol. Survey Water-Supply Paper 1365, $105 \mathrm{p}$. 
A11 wells are drilled unless otherwise noted in remarks column.

Water level : Reported water levels given in feet; measured water levels given in feet and tenths.

Method of lift and type of power: B, bucket; C, centrifugal; G, gasoline, butane, or diesel engine; H, hand; J, jet; N, none; P, piston;

Use of water

: D, domestic; Ind, industrial; P, public supply; S, livestock; U, unused.

\begin{tabular}{|c|c|c|c|c|c|c|c|c|c|c|c|}
\hline \multirow[b]{2}{*}{ WELLL } & \multirow[b]{2}{*}{ OWNER } & \multirow[b]{2}{*}{ DRTLLER } & \multirow[b]{2}{*}{$\begin{array}{l}\text { DATE } \\
\text { COM- } \\
\text { PLET- } \\
\text { ED }\end{array}$} & \multirow[b]{2}{*}{$\begin{array}{l}\text { DEPTH } \\
\text { OF } \\
\text { WELL } \\
\text { (FT) }\end{array}$} & \multirow[b]{2}{*}{$\begin{array}{c}\text { DIAM- } \\
\text { ETER } \\
\text { OF } \\
\text { WELL } \\
\text { (IN.) }\end{array}$} & \multirow[b]{2}{*}{$\begin{array}{l}\text { ALTITUDE } \\
\text { OF LAND } \\
\text { SURFACE } \\
\text { (FT) }\end{array}$} & \multicolumn{2}{|c|}{ WATER LEVEL } & \multirow[b]{2}{*}{$\begin{array}{l}\text { METHOD } \\
\text { OF } \\
\text { LIFT }\end{array}$} & \multirow[b]{2}{*}{$\begin{array}{l}\text { USE } \\
\text { OF } \\
\text { WATER }\end{array}$} & \multirow[b]{2}{*}{ REMARKS } \\
\hline & & & & & & & $\begin{array}{l}\text { BELOW LAND } \\
\text { SURFACE } \\
\text { DATUM } \\
\text { (FT) }\end{array}$ & $\begin{array}{c}\text { DATE OF } \\
\text { MEASUREMENT }\end{array}$ & & & \\
\hline
\end{tabular}

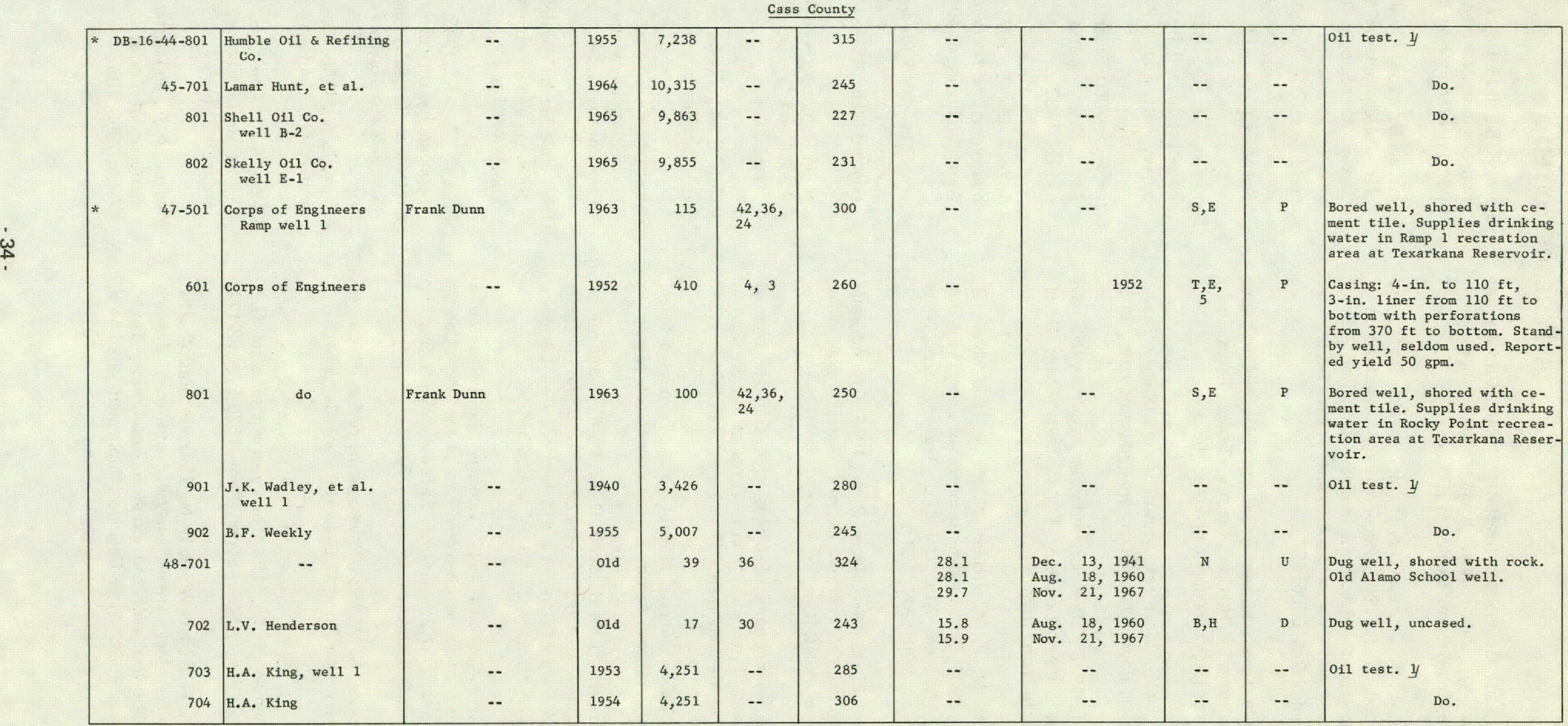

See footnotes at end of table. 
Table 7.-- Records of Wells and Springs in Cass and Marion Counties--Continued

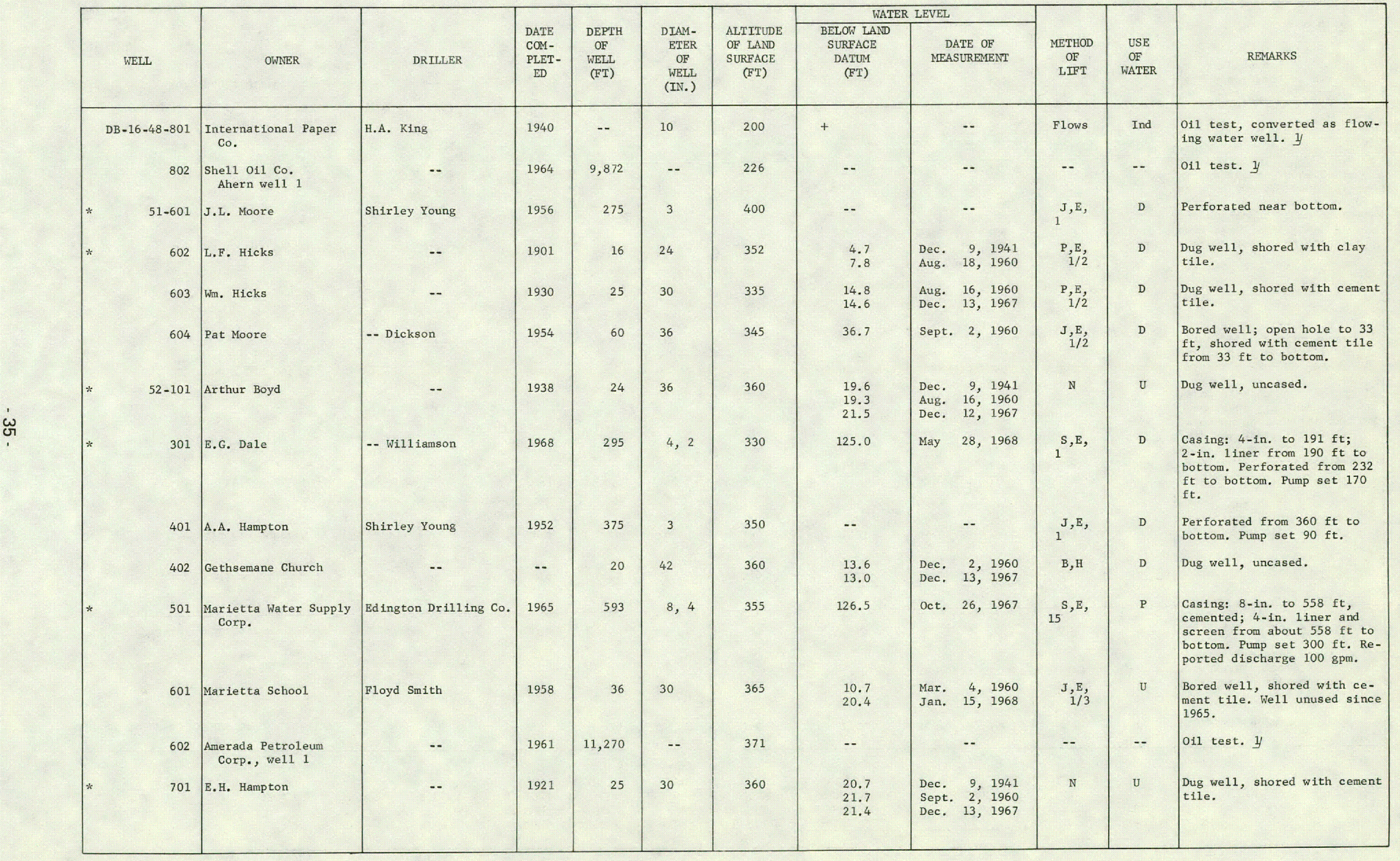

See footnotes at end of table. 
Table 7..- Records of Wells and Springs in Cass and Marion Counties--Continued

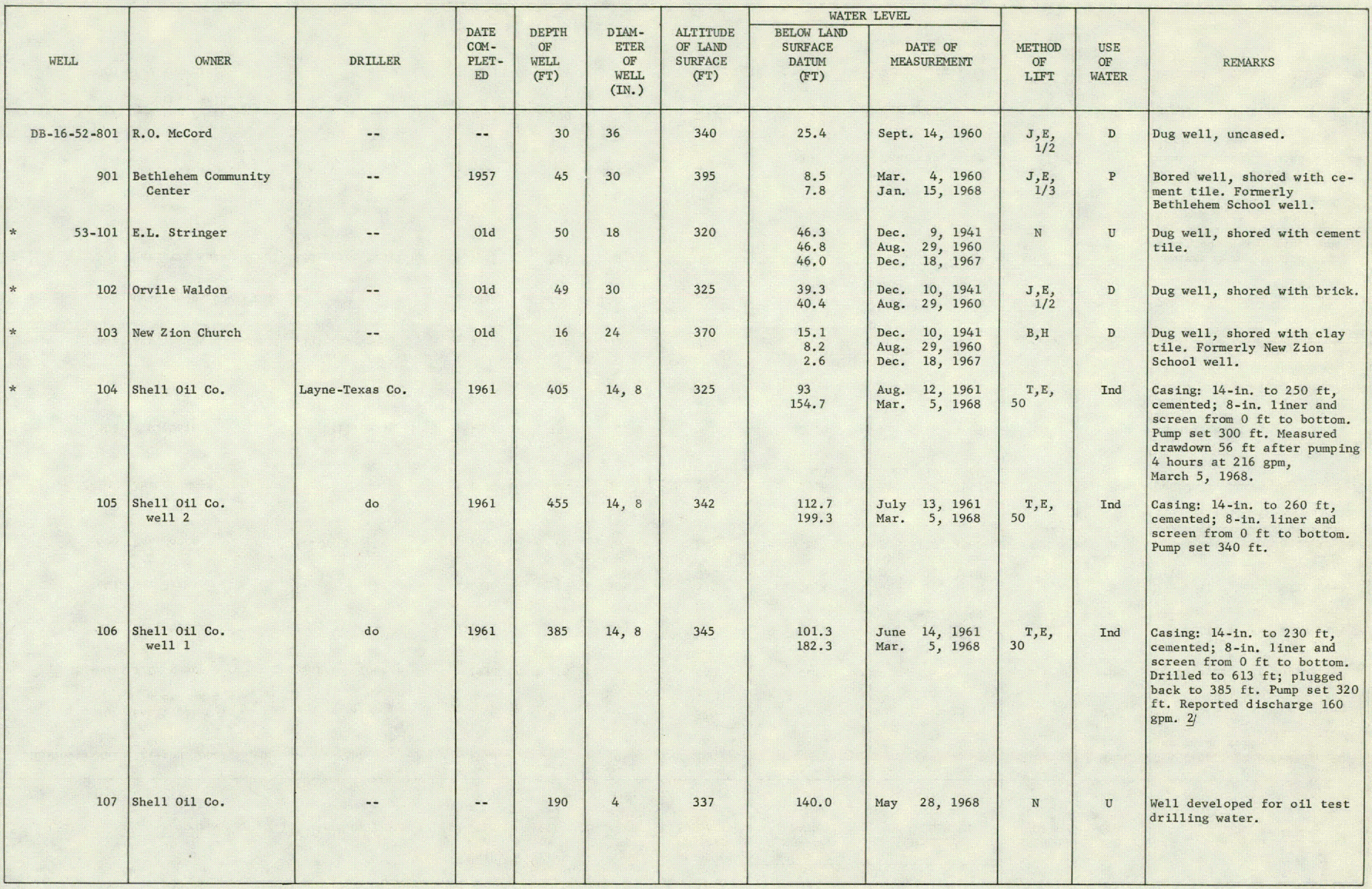

See footnotes at end of table. 
Table 7.-- Records of Wells and Springs in Cass and Marion Counties--Continued

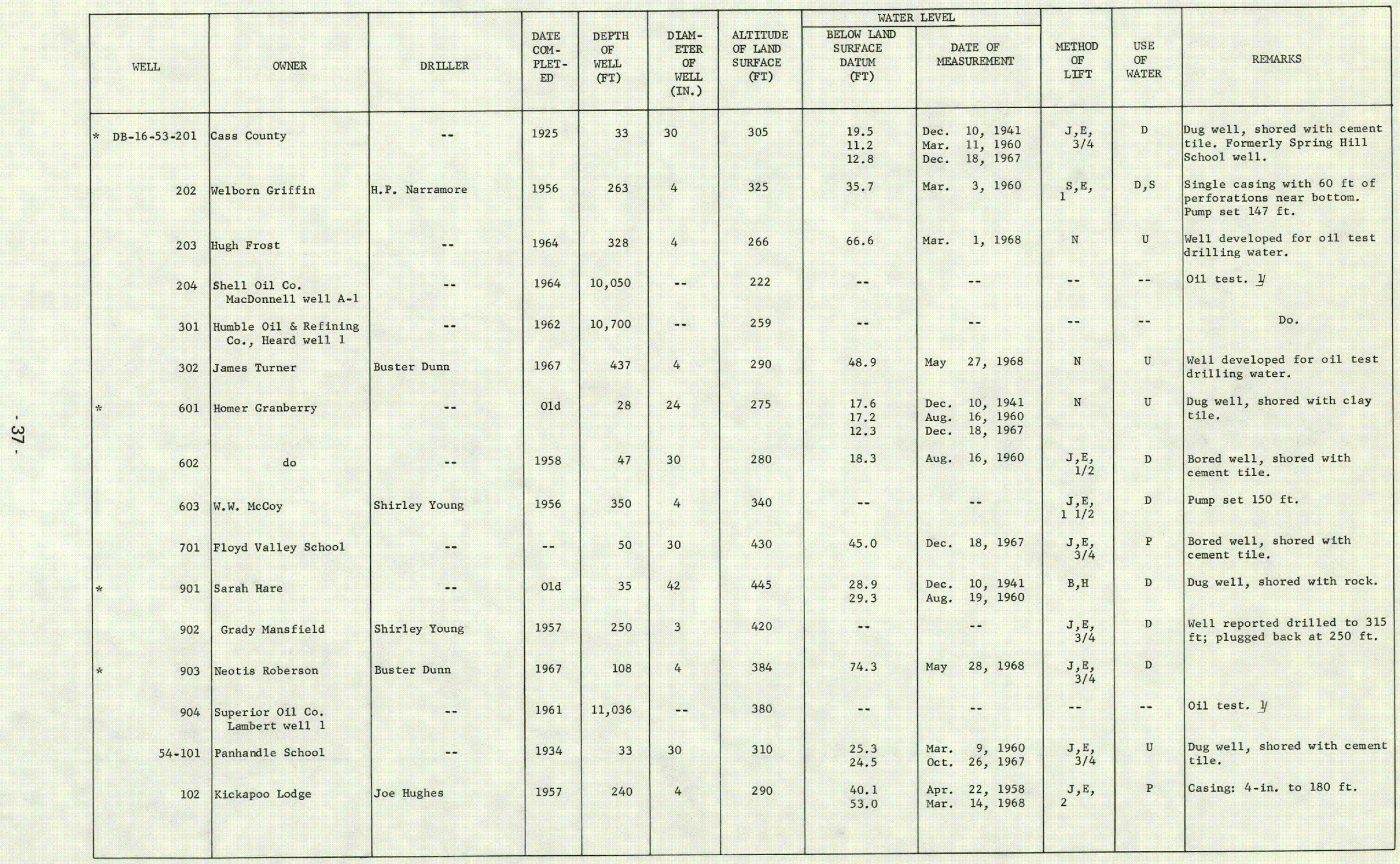

See footnotes at end of table. 
Table 7.-- Records of Wells and Springs in Cass and Marion Counties--Continued

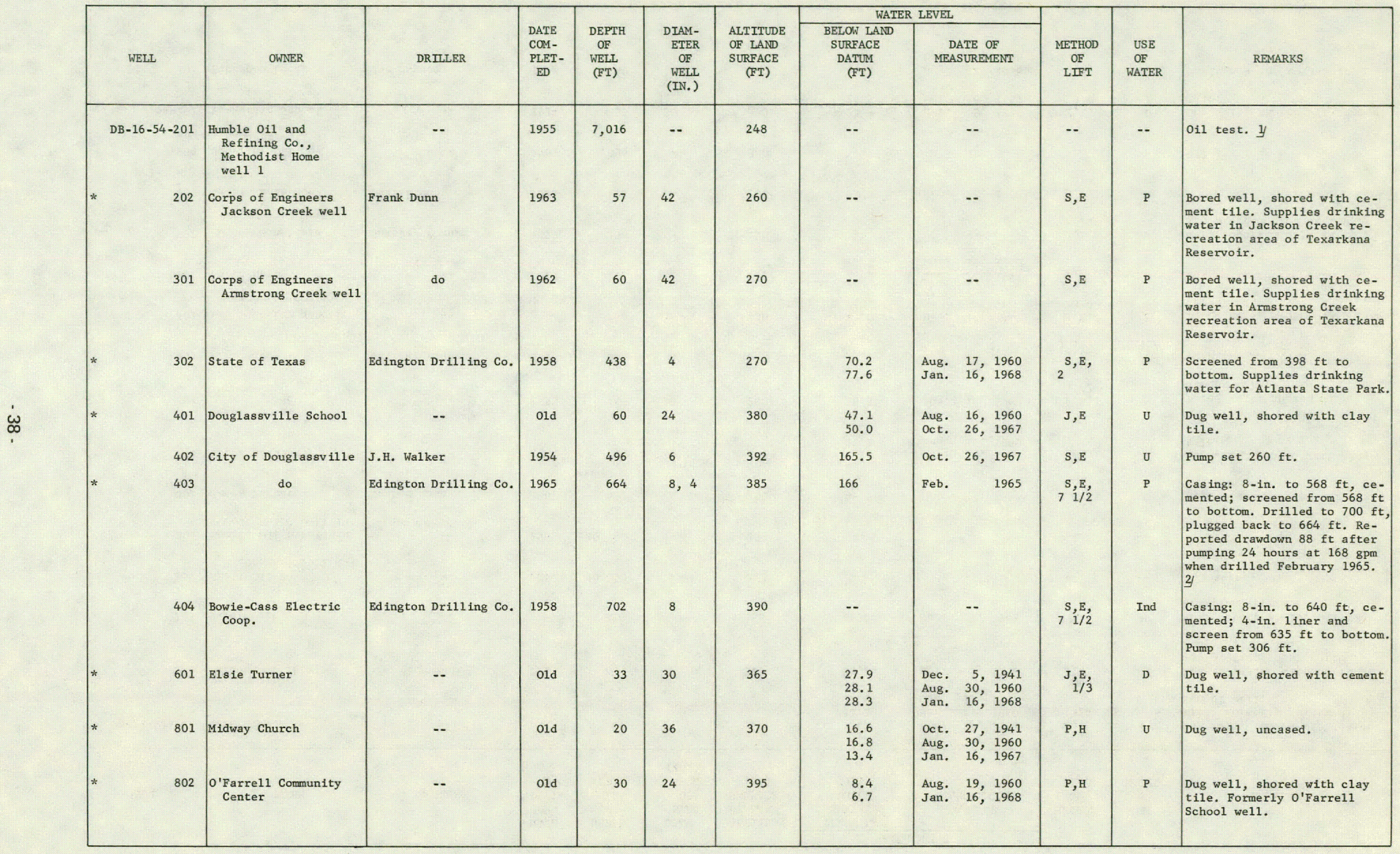

See footnotes at end of table. 
Table 7..- Records of Wells and Springs in Cass and Marion Counties--Continued

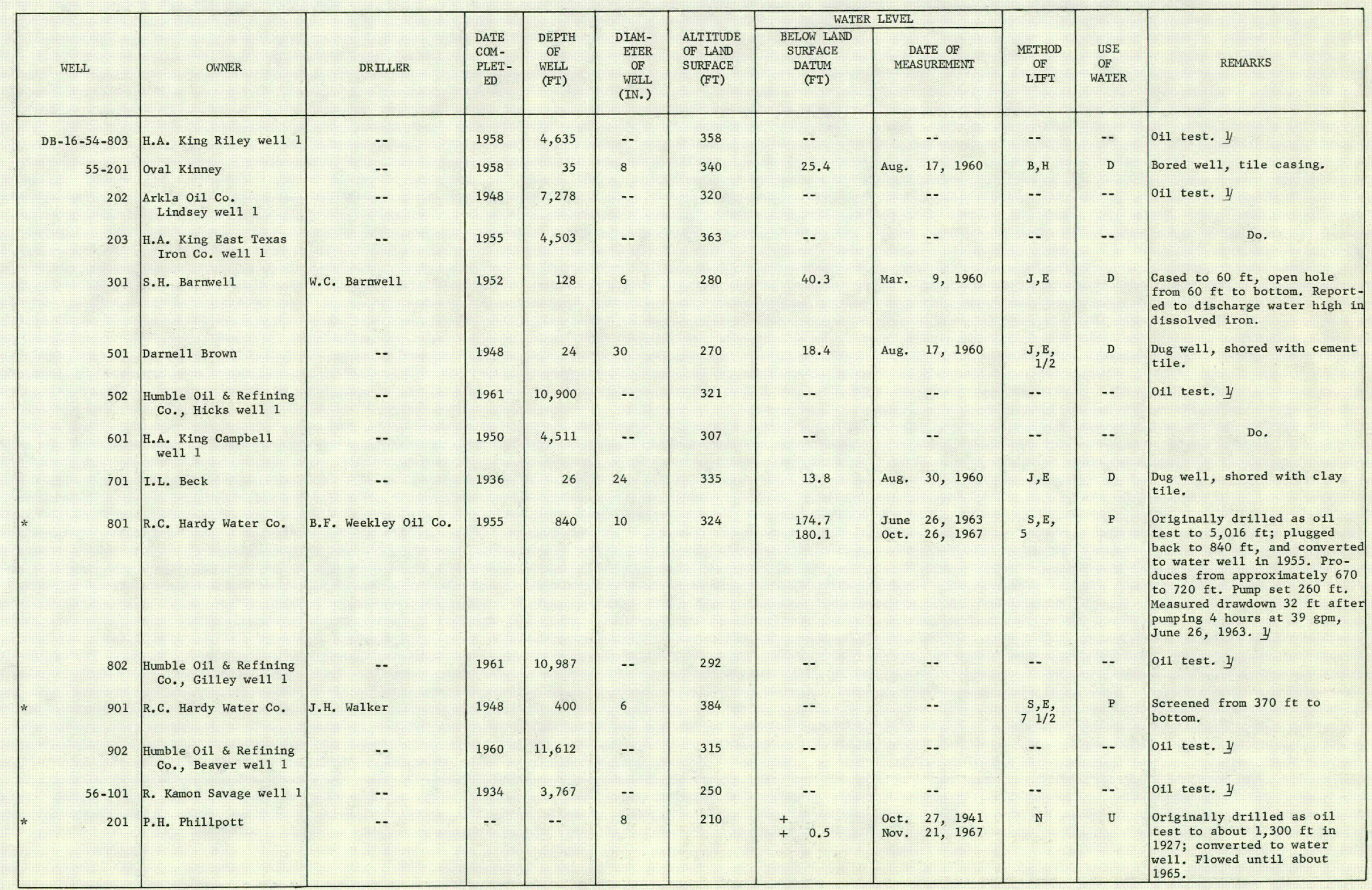

See footnotes at end of table. 
Table 7.-- Records of Wells and Springs in Cass and Marion Counties--Continued

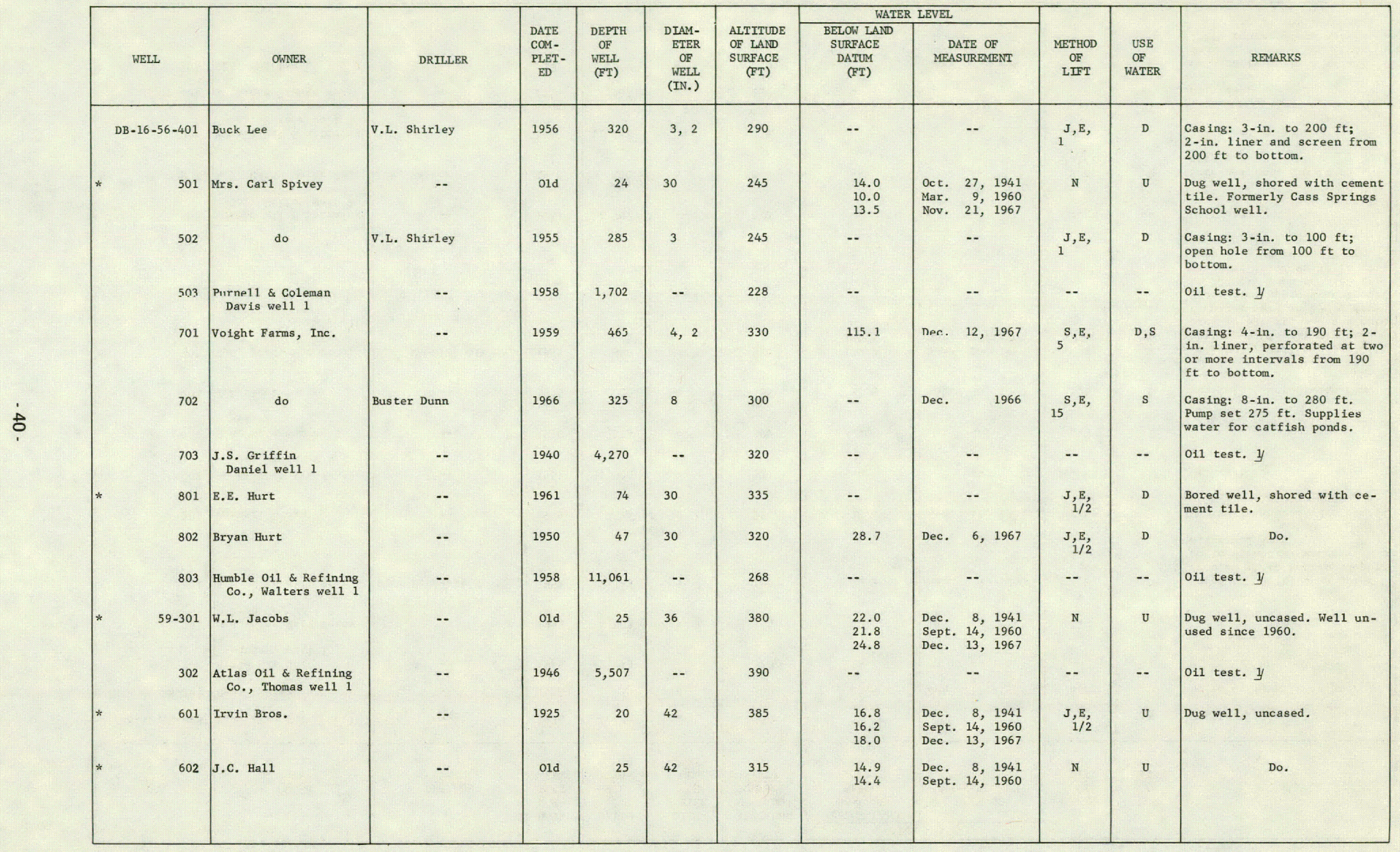

See footnotes at end of table. 
Table 7..- Records of Wells and Springs in Cass and Marion Counties--Continued

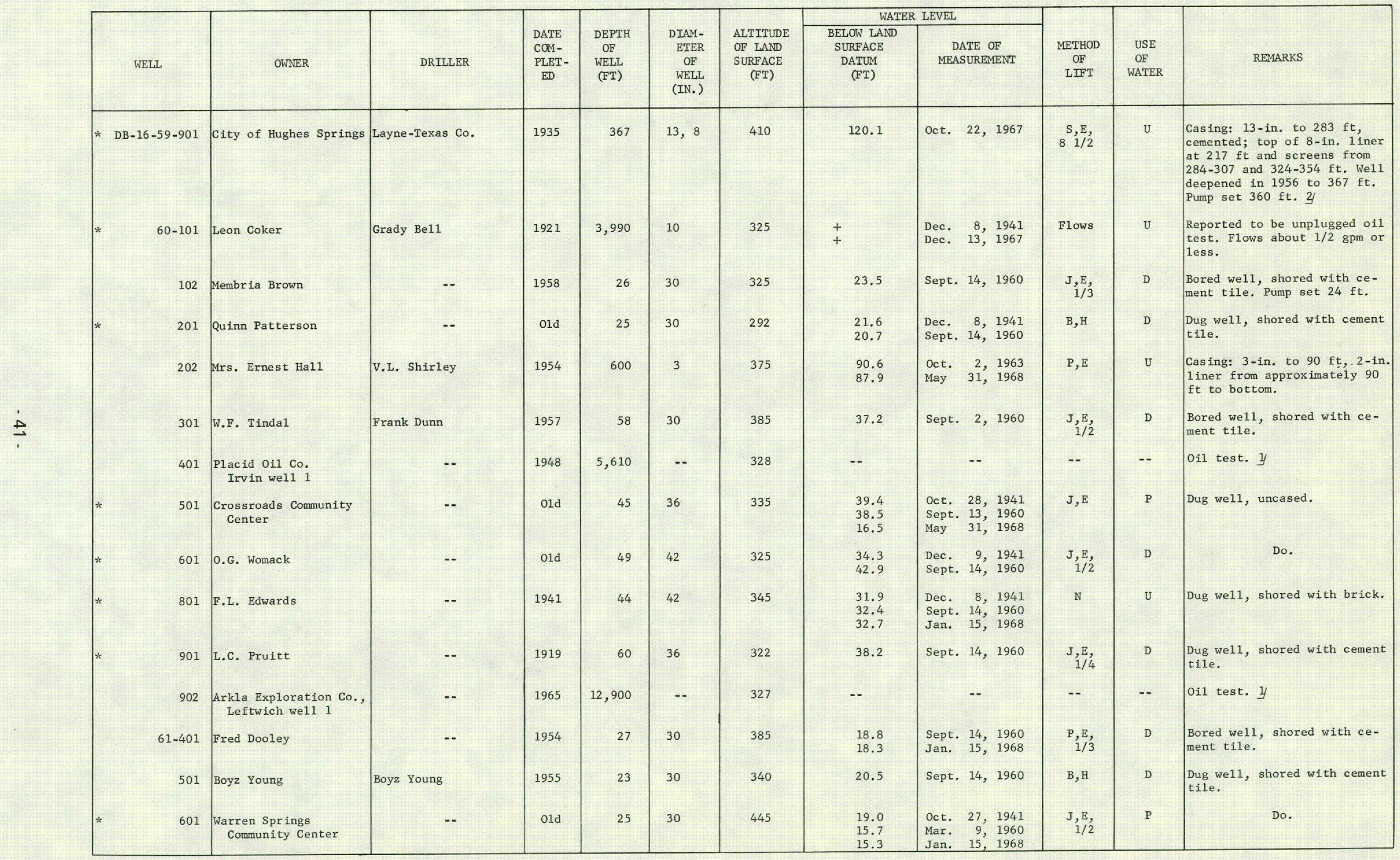

See footnotes at end of table. 
Table 7.-. Records of Wells and Springs in Cass and Marion Counties--Continued

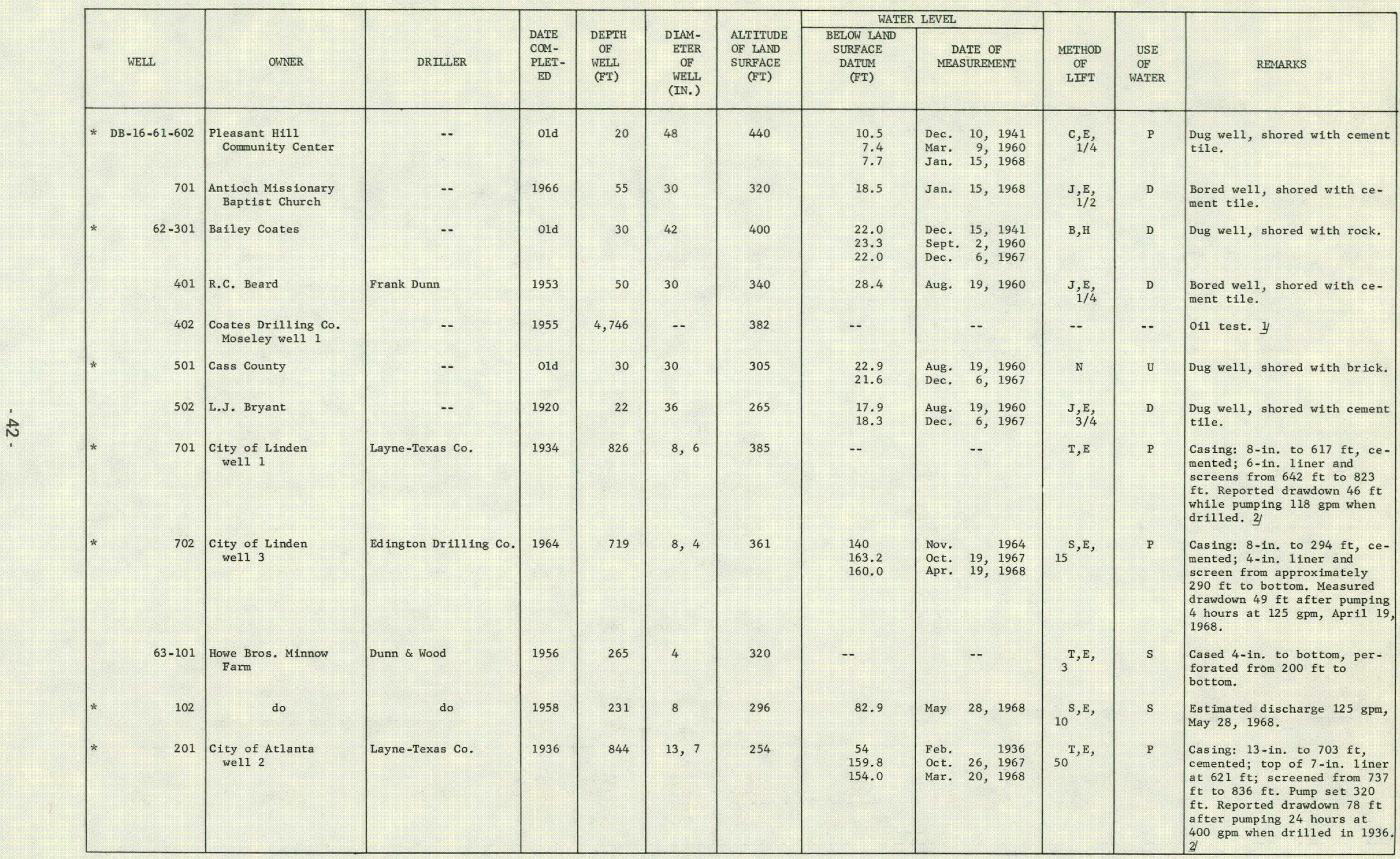

See footnotes at end of table. 
Table 7.-- Records of Wells and Springs in Cass and Marion Counties--Continued

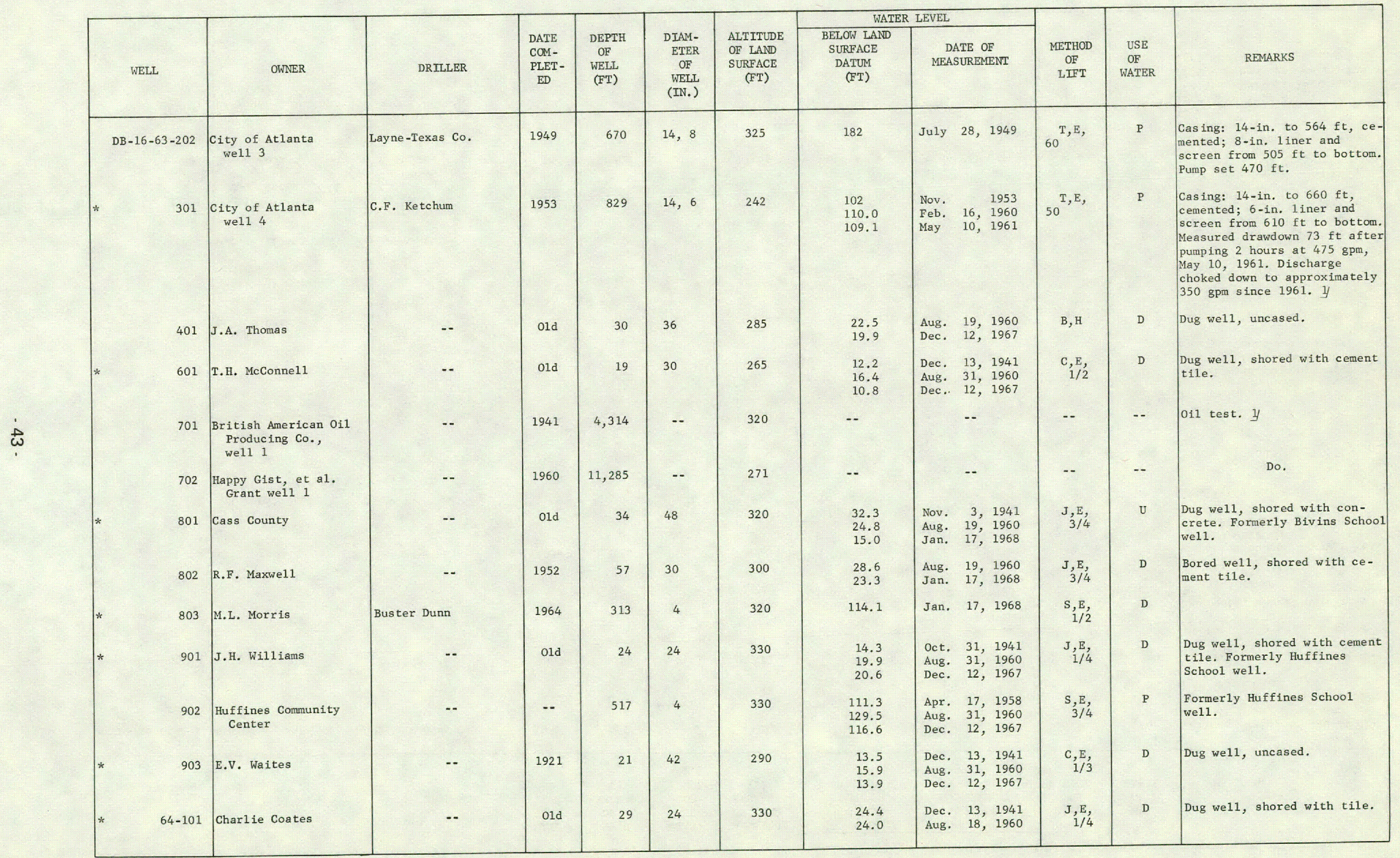

See footnotes at end of table. 
Table 7..- Records of Wells and Springs in Cass and Marion Counties--Continued

\begin{tabular}{|c|c|c|c|c|c|c|c|c|c|c|c|}
\hline \multirow[b]{2}{*}{ WELL } & \multirow[b]{2}{*}{ OWNER } & \multirow[b]{2}{*}{ DRILLER } & \multirow[b]{2}{*}{$\begin{array}{l}\text { DATE } \\
\text { COM- } \\
\text { PLET- } \\
\text { ED }\end{array}$} & \multirow[b]{2}{*}{$\begin{array}{l}\text { DEPTH } \\
\text { OF } \\
\text { WELL. } \\
\text { (FT) }\end{array}$} & \multirow[b]{2}{*}{$\begin{array}{l}\text { DIAM- } \\
\text { ETER } \\
\text { OF } \\
\text { WELL } \\
\text { (IN.) }\end{array}$} & \multirow[b]{2}{*}{$\begin{array}{l}\text { ALTITUDE } \\
\text { OF LAND } \\
\text { SURFACE } \\
\text { (FT) }\end{array}$} & \multicolumn{2}{|c|}{ WATER LEVEL } & \multirow[b]{2}{*}{$\begin{array}{l}\text { METHOD } \\
\text { OF } \\
\text { LIFT }\end{array}$} & \multirow[b]{2}{*}{$\begin{array}{l}\text { USE } \\
\text { OF } \\
\text { WATER }\end{array}$} & \multirow[b]{2}{*}{ REMARKS } \\
\hline & & & & & & & $\begin{array}{l}\text { BELOW LAND } \\
\text { SURFACE } \\
\text { DATUM } \\
\text { (FT) }\end{array}$ & $\begin{array}{l}\text { DATE OF } \\
\text { MEASUREMENT }\end{array}$ & & & \\
\hline * DB-16-64-201 & $\begin{array}{l}\text { B1oomberg Water Supp1y } \\
\text { Corp. }\end{array}$ & Layne-Texas Co. & 1964 & 450 & 10,6 & 310 & 117 & Aug. 27,1964 & $\begin{array}{l}\mathrm{S}, \mathrm{E} \\
7 \mathrm{1} / 2\end{array}$ & $P$ & $\begin{array}{l}\text { Casing: } 10-\mathrm{in} \text {. to } 330 \mathrm{ft} \text {, ce- } \\
\text { mented; 6-in. 1 iner and } \\
\text { screen from } 250 \mathrm{ft} \text { to bottom. } \\
\text { Pump set } 205 \mathrm{ft} \text {. }\end{array}$ \\
\hline 202 & J.B. Hilliard & Noah Tyson & 1967 & 253 & 4,2 & 320 & 93.9 & Dec. 12, 1967 & $\mathrm{~s}, \mathrm{E}$, & D & $\begin{array}{l}\text { Casing: } 4 \text {-in. to } 205 \mathrm{ft} \text {; } 2- \\
\text { in. liner from } 205 \mathrm{ft} \text { to } \\
\text { bottom. Pump set } 189 \mathrm{ft} \text {. }\end{array}$ \\
\hline 203 & J.A. Cantrell & $-\cdot$ & 1938 & 19 & 24 & 260 & $\begin{array}{r}6.7 \\
13.8 \\
12.2\end{array}$ & $\begin{array}{ll}\text { Dec. } & 13,1941 \\
\text { Aug. } & 18,1960 \\
\text { Nov. } & 20,1967\end{array}$ & B, H & D & Dug well, shored with tile. \\
\hline 401 & L,P. Arceneaux & Noah Tyson & 1956 & 123 & 4 & 310 & $\begin{array}{l}39.6 \\
38.7\end{array}$ & $\begin{array}{lr}\text { Aug. } & 18,1960 \\
\text { Dec. } & 5,1967\end{array}$ & $\mathrm{~N}$ & U & $\begin{array}{l}\text { Reported unused because well } \\
\text { yields water high in dis- } \\
\text { solved iron. }\end{array}$ \\
\hline 402 & $\begin{array}{l}\text { Ark1a oil Co, } \\
\text { Brooks Bros. well } 1\end{array}$ & -- & 1947 & 7,200 & -- & 220 & -- & -- & $-\cdot$ & - & oil test. y \\
\hline 501 & $\begin{array}{l}\text { Texas Eastern } \\
\text { Transport Corp. }\end{array}$ & Rayburn Drilling Co. & 1950 & 214 & 10 & 300 & $\begin{array}{l}74.4 \\
94.1\end{array}$ & $\begin{array}{l}\text { Aug. } 8,1960 \\
\text { Nov. } \quad 20,1967\end{array}$ & $3^{S, E}$ & Ind & Pump set $200 \mathrm{ft}$. \\
\hline 502 & Mrs. Beulah White & Gregg \& Wa1ker & 1955 & 200 & 4 & 320 & $\begin{array}{l}101.8 \\
102.6\end{array}$ & $\begin{array}{l}\text { Aug. } 18,1960 \\
\text { Nov. } 20,1967\end{array}$ & $S, E$ & D & \\
\hline 503 & Cecil Lummus & -- & 1955 & 206 & 4 & 260 & $\begin{array}{l}39.9 \\
44.5\end{array}$ & $\begin{array}{lr}\text { Mar. } & 8,1960 \\
\text { Nov. } & 20,1967\end{array}$ & $\begin{array}{l}\mathrm{s}, \mathrm{E} \\
1 \mathrm{1} / 2\end{array}$ & D & $\begin{array}{l}\text { Cased 4-in. to bottom; per- } \\
\text { forated from } 186 \mathrm{ft} \text { to } \\
\text { bottom. Pump set } 105 \mathrm{ft} \text {. }\end{array}$ \\
\hline 504 & A.D. G1ass & -- & 1960 & 55 & 30 & 325 & 32.2 & Dec. 5, 1967 & $\begin{array}{l}\mathrm{J}, \mathrm{E}, \\
1 / 2\end{array}$ & D & $\begin{array}{l}\text { Bored well, shored with ce- } \\
\text { ment tile. }\end{array}$ \\
\hline 505 & $\begin{array}{l}\text { Arkla } 011 \text { Co. } \\
\text { Glass well } 1\end{array}$ & -- & 1947 & 7,338 & - & 325 & $\cdots$ & -- & -- & -- & oil test. y \\
\hline 801 & W.c. Will 1ams & -- Walker & 1958 & 305 & 4 & 238 & 27.7 & May 31,1968 & $S, E$ & D & $\begin{array}{l}\text { Screened from } 270 \mathrm{ft} \text { to } \\
\text { bottom. Pump set } 40 \mathrm{ft} \text {. }\end{array}$ \\
\hline $35-03-301$ & $\begin{array}{c}\text { Humble Oil \& Refining } \\
\text { Co., Turner well } 1\end{array}$ & -- & 1952 & 8,308 & -- & 428 & -- & -- & -- & -- & Oil test. y \\
\hline 601 & Fayon Amox & 0. Holmes & 1956 & 366 & 4 & 443 & 163.9 & Sept. 12,1960 & $\mathrm{~s}, \mathrm{E}$, & D & $\begin{array}{l}\text { Cased } 4-\mathrm{in} \text {. to } 323 \mathrm{ft} \text {; open } \\
\text { hole from } 323 \mathrm{ft} \text { to bottom. } \\
\text { Pump set } 204 \mathrm{ft} \text {. }\end{array}$ \\
\hline $04-101$ & $\begin{array}{l}\text { City of Hughes Springs } \\
\text { well } 3\end{array}$ & Cooper-Herring & 1952 & 480 & 6 & 370 & 89.5 & Oct. 22,1967 & $15^{\mathrm{T}, \mathrm{E}}$ & U & $\begin{array}{l}\text { Screened from } 450 \mathrm{ft} \text { to } \\
\text { bottom. Well yield reported } \\
75 \text { gpm when last used. Pump } \\
\text { set } 335 \mathrm{ft} \text {. }\end{array}$ \\
\hline
\end{tabular}

See footnotes at end of table. 


\begin{tabular}{|c|c|c|c|c|c|c|c|c|c|c|c|c|c|c|}
\hline 童 & 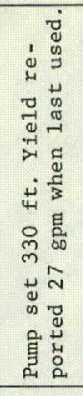 & 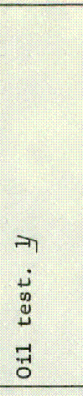 & 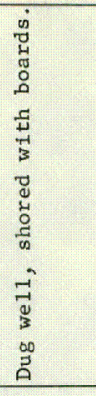 & 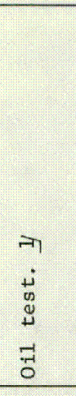 & 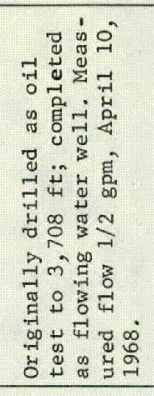 & 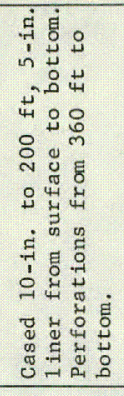 & 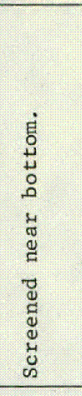 & 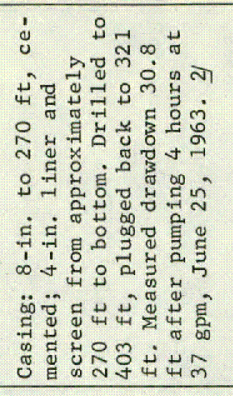 & 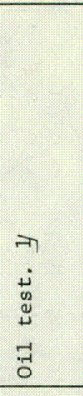 & 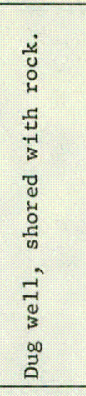 & 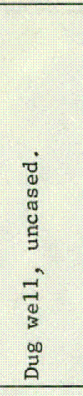 & 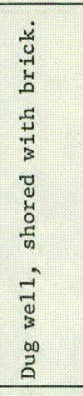 & 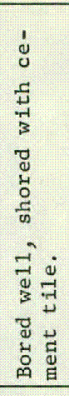 & $\begin{array}{l} \\
\Rightarrow 1 \\
\dot{0} \\
\pm \\
\dot{0} \\
\overrightarrow{0}\end{array}$ \\
\hline 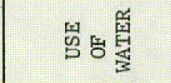 & $=$ & : & A & i & is & $=$ & A & A & : & A & A & A & A & : \\
\hline 总的昌 & जी & : & कीजी & i & $\overbrace{0}^{0}$ & $z$ & ثิ & 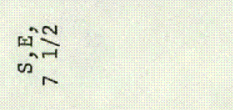 & : & m & जी & 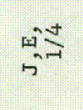 & जि & : \\
\hline 娄 基 & $\begin{array}{l}\text { ปे } \\
\text { సे } \\
\dot{8} \\
\end{array}$ & : & 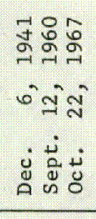 & : & 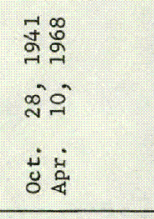 & 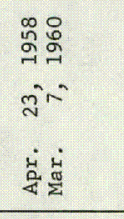 & : & 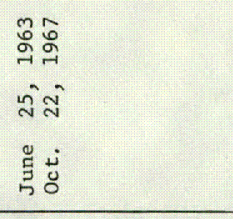 & : & 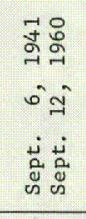 & 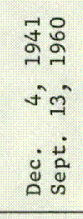 & 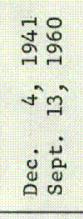 & 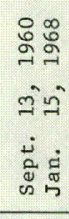 & : \\
\hline 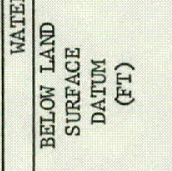 & $\vec{\Omega}$ & : & 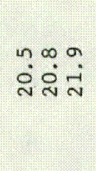 & : & ++ & 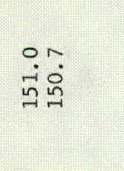 & : & 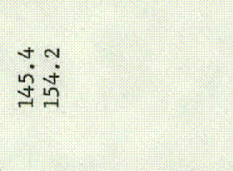 & : & تُ & 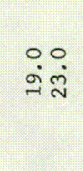 & $\begin{array}{l}9.4 \\
\text { लें }\end{array}$ & in & : \\
\hline 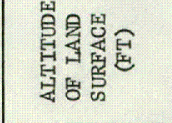 & 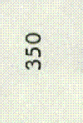 & $\vec{J}$ & $\stackrel{\leftrightarrow}{\infty}$ & : & స & : & ৪ & స్ల & ஜ్ & 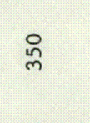 & 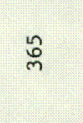 & ১্ণ & హ్ల & 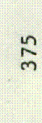 \\
\hline 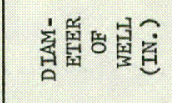 & 0 & i & $\underset{\exists}{ }$ & : & 구 & i & $\infty$ & $\infty$ & i & ร & ஜ & q & ㅇ & : \\
\hline 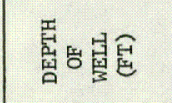 & $\underset{+}{+}$ & 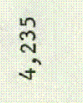 & $\stackrel{\Delta}{\Delta}$ & @্ণ্ণী & : & $\underset{m}{\stackrel{\infty}{0}}$ & ơ & $\vec{~}$ & $\begin{array}{l}\text { no } \\
\text { in }\end{array}$ & 9 & ล & ga & in & जั \\
\hline 罢客悹国 & ลूँ & 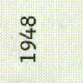 & $\Xi$ & : & ब్స & స్తి & ฏั & Љ్ & 京 & $\Xi$ & $\Xi$ & $\ddot{0}$ & ڤิ & 워 \\
\hline 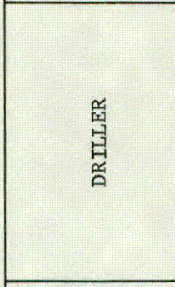 & 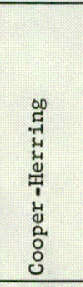 & : & : & : & : & 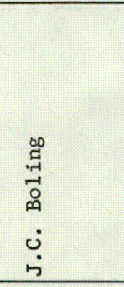 & : & 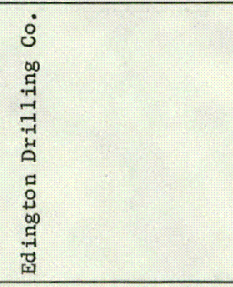 & : & : & : & : & : & : \\
\hline 愛 & 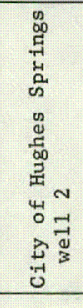 & 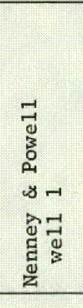 & 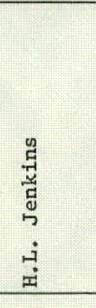 & 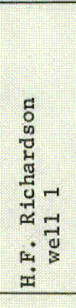 & 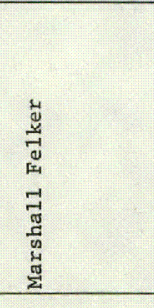 & 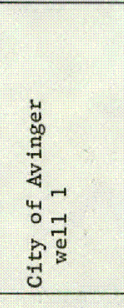 & 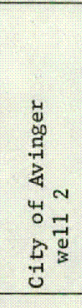 & 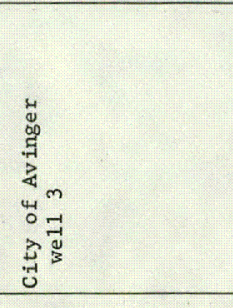 & 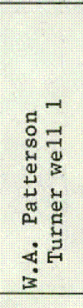 & 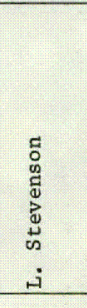 & 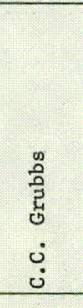 & 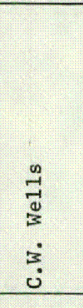 & 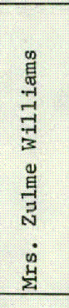 & 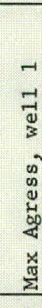 \\
\hline 鼻 & 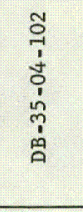 & 묘 & * & i⿱ & $\overrightarrow{8}$ & $\vec{\infty}$ & ర్ & * & ఫั & * & $\begin{array}{l}\overrightarrow{0} \\
\ddot{0} \\
\text { ถ் }\end{array}$ & * & in & iั \\
\hline
\end{tabular}


Table 7.-- Records of Wells and Springs in Cass and Marion Counties--Continued

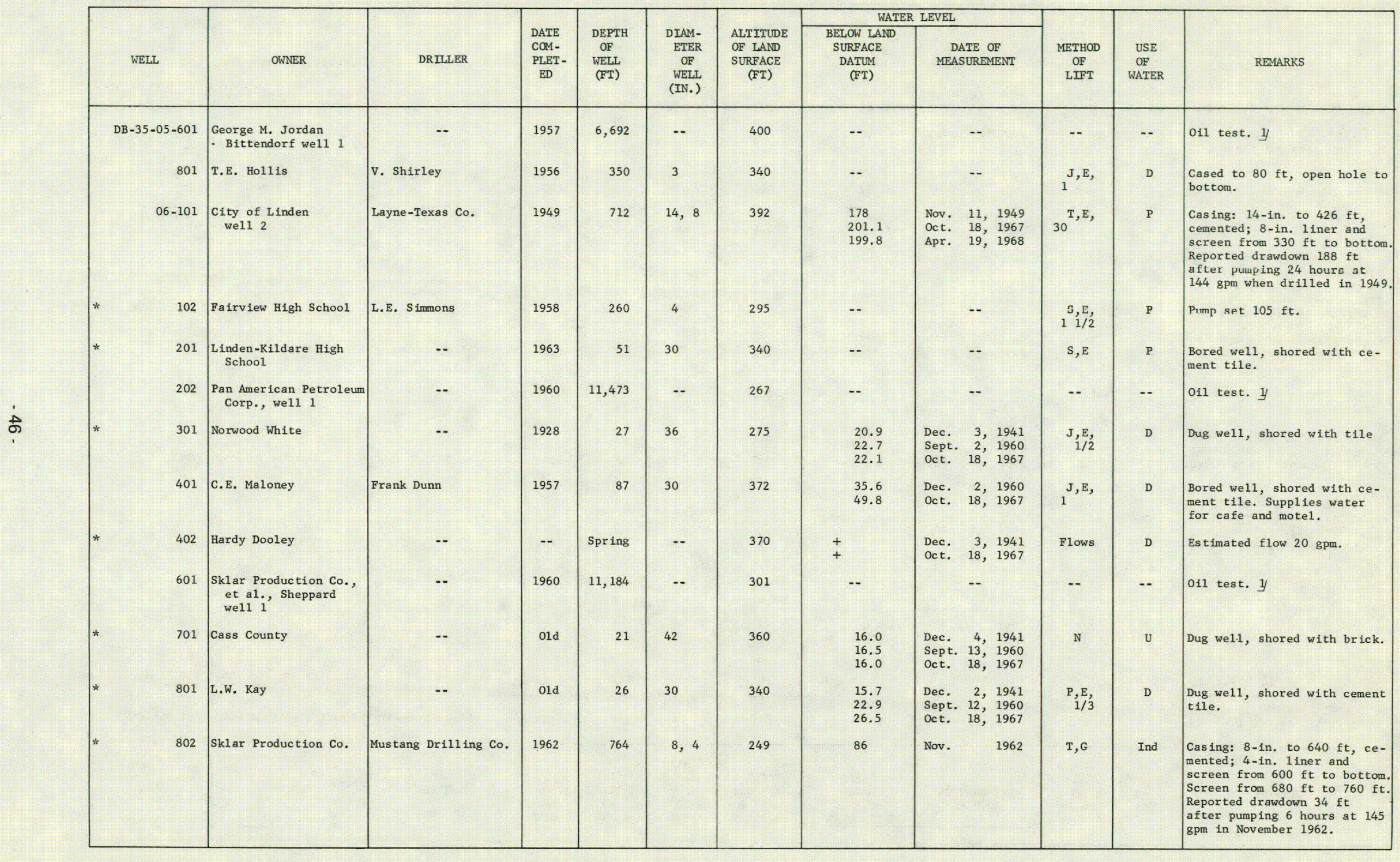

See footnotes at end of table. 
Table 7.-- Records of Wells and Springs in Cass and Marion Counties--Continued

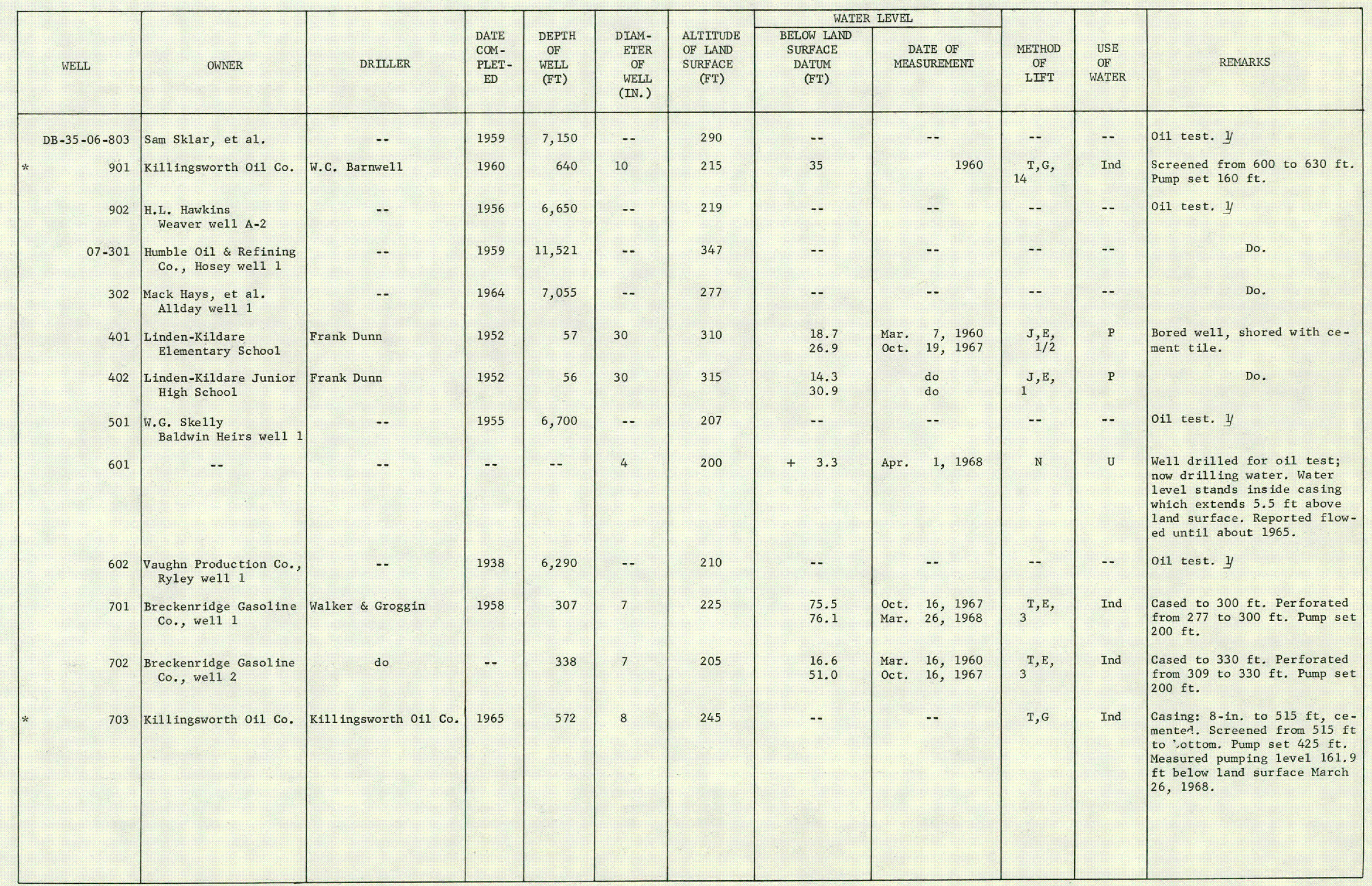

See footnotes at end of table. 
Table 7.-.- Records of Wells and Springs in Cass and Marion Counties--Continued

\begin{tabular}{|c|c|c|c|c|c|c|c|c|c|c|c|c|c|c|}
\hline \multirow{2}{*}{\multicolumn{2}{|c|}{ WELL }} & \multirow[b]{2}{*}{ OWNER } & \multirow[b]{2}{*}{ DRTLLER } & \multirow[b]{2}{*}{$\begin{array}{l}\text { DATE } \\
\text { COM- } \\
\text { PLET- } \\
\text { ED }\end{array}$} & \multirow[b]{2}{*}{$\begin{array}{l}\text { DEPTH } \\
\text { OF } \\
\text { WELL } \\
\text { (FT) }\end{array}$} & \multirow[b]{2}{*}{$\begin{array}{l}\text { DIAM- } \\
\text { ETER } \\
\text { OF } \\
\text { WELL } \\
\text { (IN.) }\end{array}$} & \multirow[b]{2}{*}{$\begin{array}{l}\text { ALTITUDE } \\
\text { OF LAND } \\
\text { SURFACE } \\
\text { (FT) }\end{array}$} & \multicolumn{4}{|c|}{ WATER LEVEL } & \multirow[b]{2}{*}{$\begin{array}{l}\text { METHOD } \\
\text { OF } \\
\text { LIFT }\end{array}$} & \multirow[b]{2}{*}{$\begin{array}{l}\text { USE } \\
\text { OF } \\
\text { WATER }\end{array}$} & \multirow[b]{2}{*}{ REMARKS } \\
\hline & & & & & & & & $\begin{array}{l}\text { BELOW LAND } \\
\text { SURFACE } \\
\text { DATUM } \\
\text { (FT) }\end{array}$ & & $\begin{array}{l}\text { ATE OF } \\
\text { SUREME }\end{array}$ & $\begin{array}{l}\text { F } \\
\text { ENT }\end{array}$ & & & \\
\hline * & DB $-35-07-704$ & Kill ingsworth oil Co. & Killingsworth Oil Co. & 1966 & 287 & 7 & 245 & -- & & -- & & $\mathrm{T}, \mathrm{G}$ & Ind & $\begin{array}{l}\text { Casing: } 7 \text {-in. to } 225 \mathrm{ft} \text {, ce- } \\
\text { mented. Screened from } 256 \mathrm{ft} \\
\text { to bottom. Pump set } 209 \mathrm{ft} \text {. } \\
\text { We11 located } 20 \mathrm{ft} \text { north of } \\
\text { DB-35-07-703. }\end{array}$ \\
\hline & 705 & do & Mustang Drilling Co. & 1964 & 700 & 8,4 & 245 & -- & & -- & & $\mathrm{T}, \mathrm{G}$ & Ind & $\begin{array}{l}\text { Casing: } 8 \text {-in. to } 643 \mathrm{ft} \text {, ce- } \\
\text { mented; } 4-\text { in. } 1 \text { iner and } \\
\text { screen from } 606 \mathrm{ft} \text { to bottom. } \\
\text { Pump set } 425 \mathrm{ft} \text {. }\end{array}$ \\
\hline \multirow[t]{6}{*}{$*$} & 801 & $\begin{array}{l}\text { Livingston Oil Co. } \\
\text { well } 1\end{array}$ & do & 1964 & 715 & 8,4 & 250 & $\begin{array}{c}74 \\
178.9\end{array}$ & $\begin{array}{l}\text { July } \\
\text { Apr. }\end{array}$ & 1, & $\begin{array}{l}1964 \\
1968\end{array}$ & $\mathrm{~T}, \mathrm{G}$ & Ind & $\begin{array}{l}\text { Casing: } 8 \text {-in. to } 505 \mathrm{ft} \text {, ce- } \\
\text { mented; } 4-\text { in. } 1 \text { iner and } \\
\text { scieed from } 405 \mathrm{ft} \text { to bottom. } \\
\text { Measured pumping } 1 \text { evel } 204.7 \\
\text { ft below land surface March } \\
25,1968 \text {. }\end{array}$ \\
\hline & 802 & $\begin{array}{l}\text { Livingston } 0 \text { il Co. } \\
\text { well } 2\end{array}$ & do & 1964 & 672 & 8,4 & 249 & $\begin{array}{c}69 \\
178.0\end{array}$ & $\begin{array}{l}\text { Aug. } \\
\text { Apr. }\end{array}$ & 1, & $\begin{array}{l}1964 \\
1968\end{array}$ & $\mathrm{~T}, \mathrm{G}$ & Ind & $\begin{array}{l}\text { Casing: } 8 \text {-in. to } 590 \mathrm{ft} \text {, ce- } \\
\text { mented; 4-in. } 1 \text { iner and } \\
\text { screen from } 552 \mathrm{ft} \text { to bottom. } \\
\text { Measured drawdown } 34.2 \mathrm{ft} \\
\text { after pumping } 4 \text { hours at } 230 \\
\text { gpm, April 1, } 1968 .\end{array}$ \\
\hline & 803 & $\begin{array}{l}\text { Livings ton oil Co. } \\
\text { well } 3\end{array}$ & do & 1964 & 675 & 8,4 & 270 & -- & & -- & & $\mathrm{T}, \mathrm{G}$ & Ind & $\begin{array}{l}\text { Casing: } 8 \text {-in. to } 585 \mathrm{ft} \text {, ce- } \\
\text { mented; } 4 \text {-in. liner and } \\
\text { screen from } 547 \mathrm{ft} \text { to bottom. }\end{array}$ \\
\hline & 804 & $\begin{array}{l}\text { Livingston } 0 \text { il Co. } \\
\text { well } 4\end{array}$ & do & 1964 & 708 & 8,4 & 243 & $\begin{array}{l}105 \\
166.6\end{array}$ & $\begin{array}{l}\text { Oct. } \\
\text { Apr. }\end{array}$ & 1, & $\begin{array}{l}1964 \\
1968\end{array}$ & $\mathrm{~T}, \mathrm{G}$ & Ind & $\begin{array}{l}\text { Casing: } 8 \text {-in. to } 620 \mathrm{ft} \text {, ce- } \\
\text { mented; 4-in. 1iner and } \\
\text { screen from } 580 \mathrm{ft} \text { to bottom. } \\
\text { Measured pumping level } 183.4 \\
\text { ft below land surface March } \\
25,1968 \text {. }\end{array}$ \\
\hline & 805 & do & $-\cdot$ & - & 350 & 7 & 200 & $\begin{array}{l}42.5 \\
46.1\end{array}$ & $\begin{array}{l}\text { Oct. } \\
\text { Mar. }\end{array}$ & $\begin{array}{l}16, \\
26\end{array}$ & $\begin{array}{l}1967 \\
1968\end{array}$ & $\mathrm{~T}, \mathrm{G}$ & Ind & $\begin{array}{l}\text { Screened from } 260 \mathrm{ft} \text {. Stand- } \\
\text { by we11, unused for more than } \\
\text { a year at the time of last } \\
\text { water leve1 measurement, } \\
\text { March } 26,1968 \text {. }\end{array}$ \\
\hline & 806 & Killingsworth oil Co. & Killingsworth Oil Co. & 1965 & 657 & 7,4 & 212 & 60 & Aug. & & 1965 & $\mathrm{~T}, \mathrm{G}$ & Ind & $\begin{array}{l}\text { Casing: } 7 \text {-in. to } 611 \mathrm{ft} \text {, ce- } \\
\text { mented; } 4 \text {-in. } 1 \text { iner and } \\
\text { screen from about } 572 \text { to } 657 \\
\text { ft. Pump set } 225 \mathrm{ft} \text {. }\end{array}$ \\
\hline * & 901 & $\begin{array}{l}\text { Breckenridge Gasol ine } \\
\text { Co. }\end{array}$ & $\begin{array}{l}\text { Phillips Petroleum } \\
\text { Co. }\end{array}$ & 1937 & 300 & 7 & 207 & -- & & -. & & ${ }_{5}^{\mathrm{S}, \mathrm{E}}$ & Ind & $\begin{array}{l}\text { Cased to } 254 \mathrm{ft} \text {, gravel-fill- } \\
\text { ed hole from } 254 \mathrm{ft} \text { to } \\
\text { bottom. Pump set } 220 \mathrm{ft} \text {. }\end{array}$ \\
\hline
\end{tabular}

See footnotes at end of table. 
Table 7.-- Records of Wells and Springs in Cass and Marion Counties--Continued

\begin{tabular}{|c|c|c|c|c|c|c|c|c|c|c|c|c|}
\hline \multirow[b]{2}{*}{ WELL } & \multirow[b]{2}{*}{ OWNER } & \multirow[b]{2}{*}{ DRILLER } & \multirow[b]{2}{*}{$\begin{array}{l}\text { DATE } \\
\text { COM- } \\
\text { PLET- } \\
\text { ED }\end{array}$} & \multirow[b]{2}{*}{$\begin{array}{l}\text { DEPTH } \\
\text { OF } \\
\text { WELL } \\
\text { (FT) }\end{array}$} & \multirow[b]{2}{*}{$\begin{array}{l}\text { DIAM- } \\
\text { ETER } \\
\text { OF } \\
\text { WELL } \\
\text { (IN.) }\end{array}$} & \multirow[b]{2}{*}{$\begin{array}{l}\text { ALTITUDE } \\
\text { OF LAND } \\
\text { SURFACE } \\
\text { (FT) }\end{array}$} & \multicolumn{3}{|c|}{ WATER LEVEL } & \multirow[b]{2}{*}{$\begin{array}{l}\text { METHOD } \\
\text { OF } \\
\text { LIFT }\end{array}$} & \multirow[b]{2}{*}{$\begin{array}{l}\text { USE } \\
\text { OF } \\
\text { WATER }\end{array}$} & \multirow[b]{2}{*}{ REMARKS } \\
\hline & & & & & & & $\begin{array}{l}\text { BELOW LAND } \\
\text { SURFACE } \\
\text { DATUM } \\
\text { (FT) }\end{array}$ & & $\begin{array}{l}\text { ITE OF } \\
\text { SUREMENT }\end{array}$ & & & \\
\hline DB $-35-07-902$ & $\begin{array}{l}\text { Breckenridge Gasoline } \\
\text { Co. }\end{array}$ & $\begin{array}{l}\text { Phillips Petroleum } \\
\text { Co. }\end{array}$ & 1937 & 300 & 6 & 200 & 85.4 & Oct. & 16,1967 & $\mathrm{~N}$ & U & \\
\hline 903 & do & do & 1937 & 1,000 & 8 & 198 & -- & & -- & $\mathrm{T}, \mathrm{G}$ & Ind & Pump set $220 \mathrm{ft}$. \\
\hline 904 & $\begin{array}{l}\text { Superior Oil } \\
\text { Production Co. } \\
\text { Chatten well i }\end{array}$ & -- & 1936 & 5,945 & -- & 200 & -- & & -- & -- & -- & oil test. Iy \\
\hline 905 & Arthur Arnold & Wa1ter Meller & 1936 & 640 & 6 & 192 & $\begin{array}{l}20.3 \\
84.4\end{array}$ & $\begin{array}{l}\text { Oct. } \\
\text { Mar. }\end{array}$ & $\begin{array}{ll}29, & 1941 \\
29, & 1968\end{array}$ & $2^{P, E,}$ & D & $\begin{array}{l}\text { Perforated from } 515 \mathrm{ft} \text { to } \\
\text { bottom. Pump set } 112 \mathrm{ft} \text {. }\end{array}$ \\
\hline $08-101$ & Sklar Production Co. & $\begin{array}{l}\text { Triangle Pump \& } \\
\text { Supply Co. }\end{array}$ & 1967 & 350 & 8,4 & 256 & 74 & July & 5, 1967 & $\mathrm{~T}, \mathrm{G}$ & Ind & $\begin{array}{l}\text { Casing: } 8 \text {-in. to } 270 \mathrm{ft} \text {, ce- } \\
\text { mented; } 4-\mathrm{in} \text {. liner and } \\
\text { screen from } 218 \mathrm{ft} \text { to bottom. } \\
\text { Screened from } 270 \mathrm{ft} \text { to } 330 \\
\text { ft. Reported drawdown } 121 \mathrm{ft} \\
\text { after pumping } 4 \text { hours at } 72 \\
\text { gpm, July } 1967 \text {. }\end{array}$ \\
\hline 102 & $\begin{array}{l}\text { Sklar Production Go. } \\
\text { Starcke well B-4 }\end{array}$ & -. & 1966 & 6,105 & -- & 269 & -- & & -- & -- & -- & oil test. Iy \\
\hline 401 & David Crow & $\begin{array}{l}\text { Triangle Purm \& } \\
\text { Supply Co. }\end{array}$ & 1967 & 360 & 8,4 & 310 & -- & & $-\cdot$ & $10^{\mathrm{S}, \mathrm{E},}$ & Ind & $\begin{array}{l}\text { Casing: } 8-\text { in. to } 300 \mathrm{ft} \text {, ce- } \\
\text { mented; } 4-\text { in. } 1 \text { iner and } \\
\text { screen from } 269 \mathrm{ft} \text { to bottom. } \\
\text { Screen from } 303 \text { to } 353 \mathrm{ft} \text {. } \\
\text { Pump set } 260 \mathrm{ft} \text {. }\end{array}$ \\
\hline 402 & $\begin{array}{l}\text { Lyons Petroleum Corp., } \\
\text { et a1., Long well i }\end{array}$ & - & 1964 & 5,007 & -- & 304 & -- & & -- & -- & U & oil test. $y$ \\
\hline 501 & A.I. Tolleson & W.A. Meller & 1936 & 708 & 6 & 315 & $\begin{array}{l}137.1 \\
171.8\end{array}$ & $\begin{array}{l}\text { Mar. } \\
\text { Oct. }\end{array}$ & $\begin{array}{l}15,1960 \\
11,1967\end{array}$ & $2^{\mathrm{S}, \mathrm{E}}$ & P & $\begin{array}{l}\text { Pump set } 240 \mathrm{ft} \text {. Well } \\
\text { supplies water for McCleod } \\
\text { Community. }\end{array}$ \\
\hline 502 & $\begin{array}{l}\text { United Production } \\
\text { Corp., Terry well } 1\end{array}$ & - & 1937 & 5,660 & -- & 320 & -- & & -- & -- & -- & oil test. $y$ \\
\hline 503 & $\begin{array}{l}\text { United Production } \\
\text { Corp., Land well } 1\end{array}$ & - & 1937 & 2,335 & -- & 243 & -- & & $-\cdot$ & -- & -- & Do. \\
\hline 701 & Arthur Arnold & -- & 1936 & -- & 6 & 190 & 71.8 & Mar. & 29,1968 & $P, E$ & D & \\
\hline
\end{tabular}

Marion County

\begin{tabular}{|c|c|c|c|c|c|c|c|c|c|c|c|c|}
\hline * & SX $-35-07-706$ & Killingsworth Oil Co. & $\begin{array}{l}\text { Mustang Drilling Co. } \\
\text { Kill ingsworth Oil Co. }\end{array}$ & $\begin{array}{l}1964 \\
1967\end{array}$ & 185 & 8,4 & 220 & $\cdots$ & -- & T, G & Ind & $\begin{array}{l}\text { Casing: } 8 \text {-in. to } 602 \mathrm{ft} \text {, ce- } \\
\text { mented; 4-in. 1iner and } \\
\text { screen from } 563 \mathrm{ft} \text { to bottom } \\
\text { Screened from } 605 \text { to } 658 \mathrm{ft} \text {. } \\
\text { Screened from } 150 \text { to } 180 \mathrm{ft} \text {. } \\
\text { Pump set } 90 \mathrm{ft} \text {. }\end{array}$ \\
\hline
\end{tabular}

See footnotes at end of table. 
Table 7.-- Records of Wells and Springs in Cass and Marion Counties--Continued

\begin{tabular}{|c|c|c|c|c|c|c|c|c|c|c|c|c|c|}
\hline \multirow[b]{2}{*}{ WELL } & \multirow[b]{2}{*}{ OWNER } & \multirow[b]{2}{*}{ DRTILER } & \multirow[b]{2}{*}{$\begin{array}{l}\text { DATE } \\
\text { COM- } \\
\text { PLTT- } \\
\text { ED }\end{array}$} & \multirow[b]{2}{*}{$\begin{array}{l}\text { DEPTH } \\
\text { OF } \\
\text { WELL } \\
\text { (FT) }\end{array}$} & \multirow[b]{2}{*}{$\begin{array}{l}\text { DIAM- } \\
\text { ETER } \\
\text { OF } \\
\text { WELL } \\
\text { (IN.) }\end{array}$} & \multirow[b]{2}{*}{$\begin{array}{l}\text { ALTITUDE } \\
\text { OF LAND } \\
\text { SURFACE } \\
\text { (FT) }\end{array}$} & \multicolumn{4}{|c|}{ WATER LEVEL } & \multirow[b]{2}{*}{$\begin{array}{l}\text { METHOD } \\
\text { OF } \\
\text { LIFT }\end{array}$} & \multirow[b]{2}{*}{$\begin{array}{l}\text { USE } \\
\text { OF } \\
\text { WATER }\end{array}$} & \multirow[b]{2}{*}{ REMARKS } \\
\hline & & & & & & & $\begin{array}{l}\text { BELOW LAND } \\
\text { SURFACE } \\
\text { DATUM } \\
\text { (FT) }\end{array}$ & & $\begin{array}{l}\text { TE O } \\
\text { UUREM }\end{array}$ & $\begin{array}{l}\text { OF } \\
\text { MENT }\end{array}$ & & & \\
\hline$S X-35-11-201$ & Davis Surratt & -- & 1962 & 83 & 30 & 270 & 31.7 & Jan. & 18, & 1968 & $1_{1}^{\mathrm{J}, \mathrm{E}}$ & D & $\begin{array}{l}\text { Bored we1l, shored with ce- } \\
\text { ment tile. }\end{array}$ \\
\hline 202 & Ber1 Bishop & -- & -- & 100 & 4 & 270 & 35.4 & & do & & $\begin{array}{r}\mathrm{J}, \mathrm{E}, \\
1 / 2\end{array}$ & D & \\
\hline 203 & $\begin{array}{l}\text { L.A. Gre11ing } \\
\text { Lawrence wel1 } 1\end{array}$ & -- & 1953 & 3,831 & -- & 237 & - & & -- & & -- & -- & 0 il test. y \\
\hline 301 & B.L. Starkey & - & 1966 & 212 & 3 & 285 & $\cdots$ & & - & & $2^{\mathrm{J}, \mathrm{E},}$ & D & $\begin{array}{l}\text { Perforated from } 185 \mathrm{ft} \text { to } \\
\text { bottom. }\end{array}$ \\
\hline 302 & $\begin{array}{l}\text { L.A. Gre11ing } \\
\text { Simpson wel1 } 1\end{array}$ & -. & 1952 & 4,012 & - & 285 & $-\cdot$ & & - & & -- & -- & oil test. $y$ \\
\hline 601 & Corps of Engineers & Dickerson Water Wells & 1965 & 40 & $\begin{array}{l}42,36 \\
24\end{array}$ & 260 & 15 & Mar. & & 1965 & $\mathrm{~S}, \mathrm{E}$ & $P$ & $\begin{array}{l}\text { Bored well, cement tile cas- } \\
\text { ing; reduced frum } 42-\text {-in. } \\
\text { diameter at surface to } 24-i n \text {. } \\
\text { at bottom. Perforated from } \\
22 \text { ft to bottom. Well sup- } \\
\text { plies drinking water in Rail- } \\
\text { road Bluff recreation area } \\
\text { at Lake } 0^{\prime} \text { the Pines. }\end{array}$ \\
\hline $12-101$ & $\begin{array}{l}\text { Magnol ia Petroleum } \\
\text { Co., Orr well } 1\end{array}$ & - & 1945 & 4,522 & - & 332 & -- & & - & & -- & -- & 0 il test. $y$ \\
\hline \multirow[t]{5}{*}{ * } & $\begin{array}{l}\text { Southwestern Electric } \\
\text { Wilkes Power Plant } \\
\text { well 1-A }\end{array}$ & Wayne Hightower & 1964 & 280 & 4,2 & 290 & 52.6 & Apr. & 10, & 1968 & $\mathrm{~s}, \mathrm{E}$ & Ind & $\begin{array}{l}\text { Casing: } 4-\mathrm{in} \text {. to } 210 \mathrm{ft} \text {, ce- } \\
\text { mented; } 2 \text {-in. } 1 \text { iner and } \\
\text { screen from } 172 \mathrm{ft} \text { to bottom. } \\
\text { Screened from } 212 \text { to } 252 \mathrm{ft} \text {. } \\
\text { Pump set } 158 \mathrm{ft} \text {. }\end{array}$ \\
\hline & $\begin{array}{l}\text { Southwestern E1ectric } \\
\text { we11 } 2-\mathrm{A}\end{array}$ & Buster Dunn & 1964 & 272 & 4,2 & 290 & -- & & -- & & $S, E$ & Ind & $\begin{array}{l}\text { Casing: } 4 \text {-in. to } 231 \mathrm{ft} \text {, ce- } \\
\text { mented; } 2-\text { in. liner and } \\
\text { screen from } 212 \mathrm{ft} \text { to bottom. } \\
\text { Screened from } 233 \text { to } 272 \mathrm{ft} \text {. } \\
\text { Pump set } 157 \mathrm{ft} \text {. }\end{array}$ \\
\hline & Southwestern Electric & Wayne Hightower & - & 237 & 4,2 & 300 & - & & - & & $\mathrm{S}, \mathrm{E}$ & $P$ & $\begin{array}{l}\text { Casing: } 4 \text {-in. to } 198 \mathrm{ft} \text {, ce- } \\
\text { mented; } 2 \text {-in. liner and } \\
\text { screen from } 188 \mathrm{ft} \text { to bottom. } \\
\text { Screened from } 203 \text { to } 223 \mathrm{ft} \text {. } \\
\text { Pump set } 158 \mathrm{ft} \text {. Supplies } \\
\text { drinking water for Southwest } \\
\text { ern Electric recreation area. }\end{array}$ \\
\hline & $\begin{array}{l}\text { Dean Bros. } \\
\text { Ha1e wel1 } 1\end{array}$ & -. & 1942 & 3,769 & - & 295 & -- & & -- & & - & -- & oil test. y \\
\hline & B.L. Starkey & $-\cdot$ & 1966 & 212 & 3 & 340 & -- & & -- & & J,E, & D & $\begin{array}{l}\text { Perforated from } 188 \mathrm{ft} \text { to } \\
\text { bottom. Reported water high } \\
\text { in dissolved iron. }\end{array}$ \\
\hline
\end{tabular}

See footnotes at end of table. 


\begin{tabular}{|c|c|c|c|c|c|c|c|c|c|}
\hline 迳 & 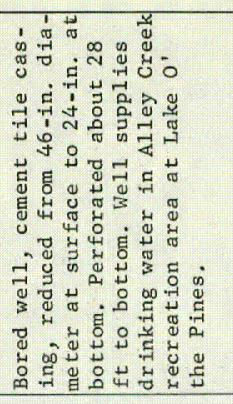 & 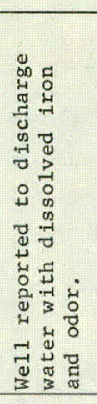 & 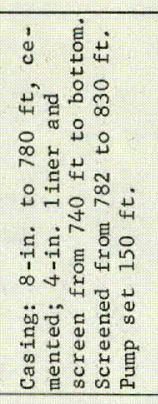 & 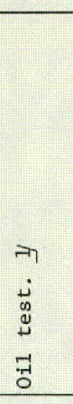 & $\dot{a}$ & 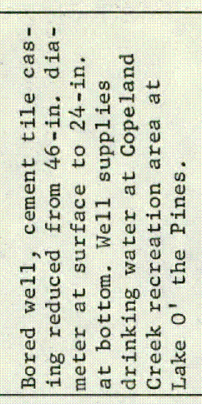 & 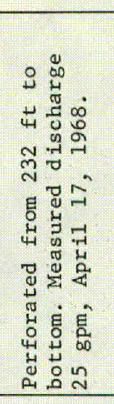 & 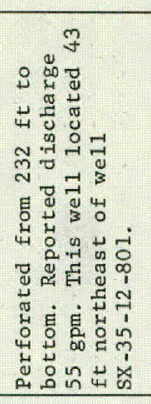 & 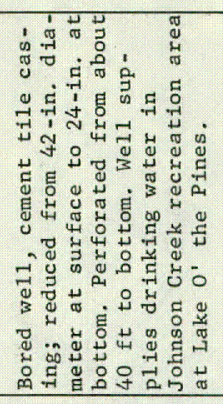 \\
\hline 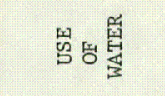 & a & A & 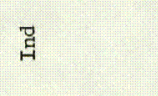 & : & i & A & A & ar & $B_{1}$ \\
\hline 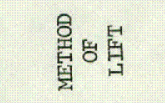 & is & धी & 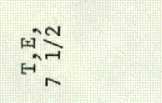 & : & : & w & $\operatorname{lin}^{n}$ & हs & $\begin{array}{l}\text { wa } \\
\text { in }\end{array}$ \\
\hline 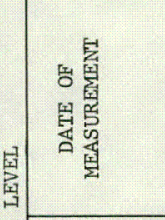 & 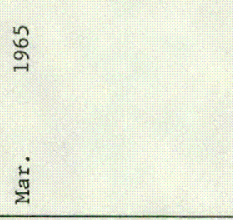 & 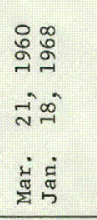 & ஓٌ & i & : & : & : & 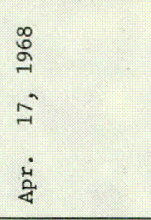 & ڤ్ \\
\hline 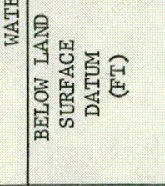 & ก & $\begin{array}{l}m \\
\dot{\omega} \\
\infty \\
\dot{n}\end{array}$ & $\vec{n}$ & : & : & : & : & के & $\vec{J}$ \\
\hline 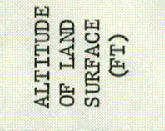 & : & ఫे & : & ลે & జ్ & 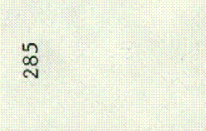 & 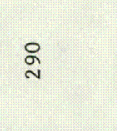 & 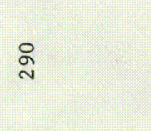 & $\stackrel{゚}{N}$ \\
\hline 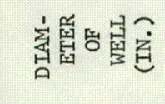 & गั่ & a & + & i & i & $\begin{array}{l}\hat{7} \\
\text { जิt }\end{array}$ & 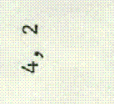 & 0 & $\begin{array}{l}\text { के } \\
\text { जे से }\end{array}$ \\
\hline 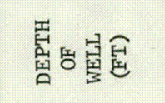 & f & $\underset{\substack{\infty \\
\sim}}{\infty}$ & ల్ల & $\stackrel{\substack{n \\
n}}{n}$ & 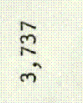 & 广ా & ลี & ล & t \\
\hline 圈客密国 & ڤొ & ڤิ & ఫั & బู & 岕 & ભ్ & ొ్ & ఏ్ & శ్ర \\
\hline 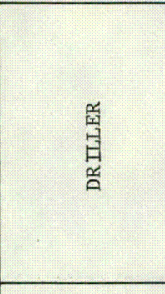 & $\begin{array}{l}n \\
7 \\
3 \\
3 \\
4 \\
0 \\
0 \\
3 \\
0 \\
0 \\
0 \\
0 \\
0 \\
ت \\
\end{array}$ & 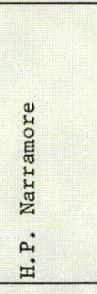 & i & : & ; & 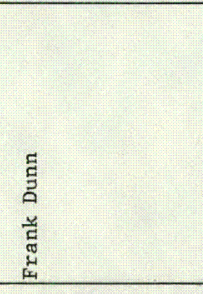 & 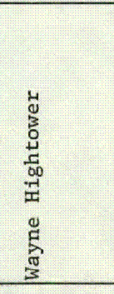 & 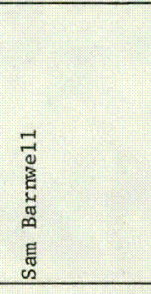 & 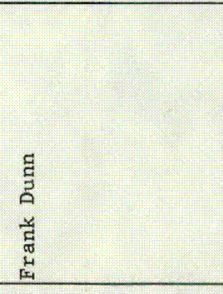 \\
\hline 學 & 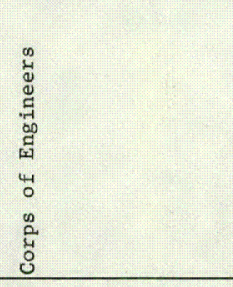 & 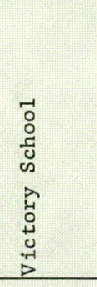 & 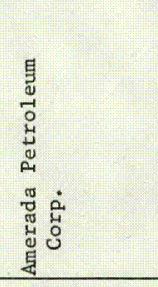 & 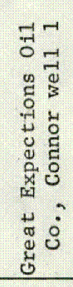 & 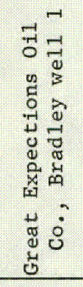 & 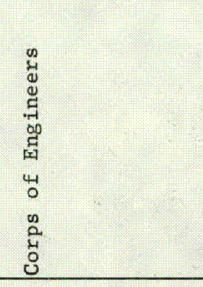 & 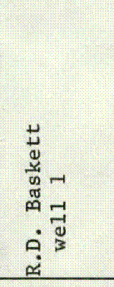 & 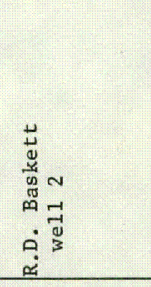 & 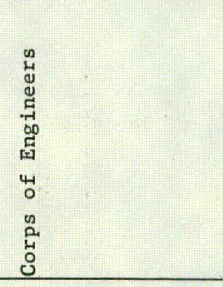 \\
\hline 宸 & 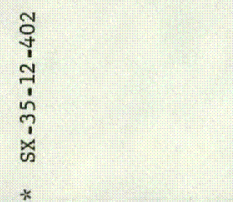 & $\overrightarrow{\tilde{n}}$ & జ్ & \% & 蒿 & $\vec{\Sigma}$ & $\vec{\infty}$ & ర్ & $\overbrace{\infty}^{\infty}$ \\
\hline
\end{tabular}


Table 7.-- Records of Wells and Springs in Cass and Marion Counties--Continued

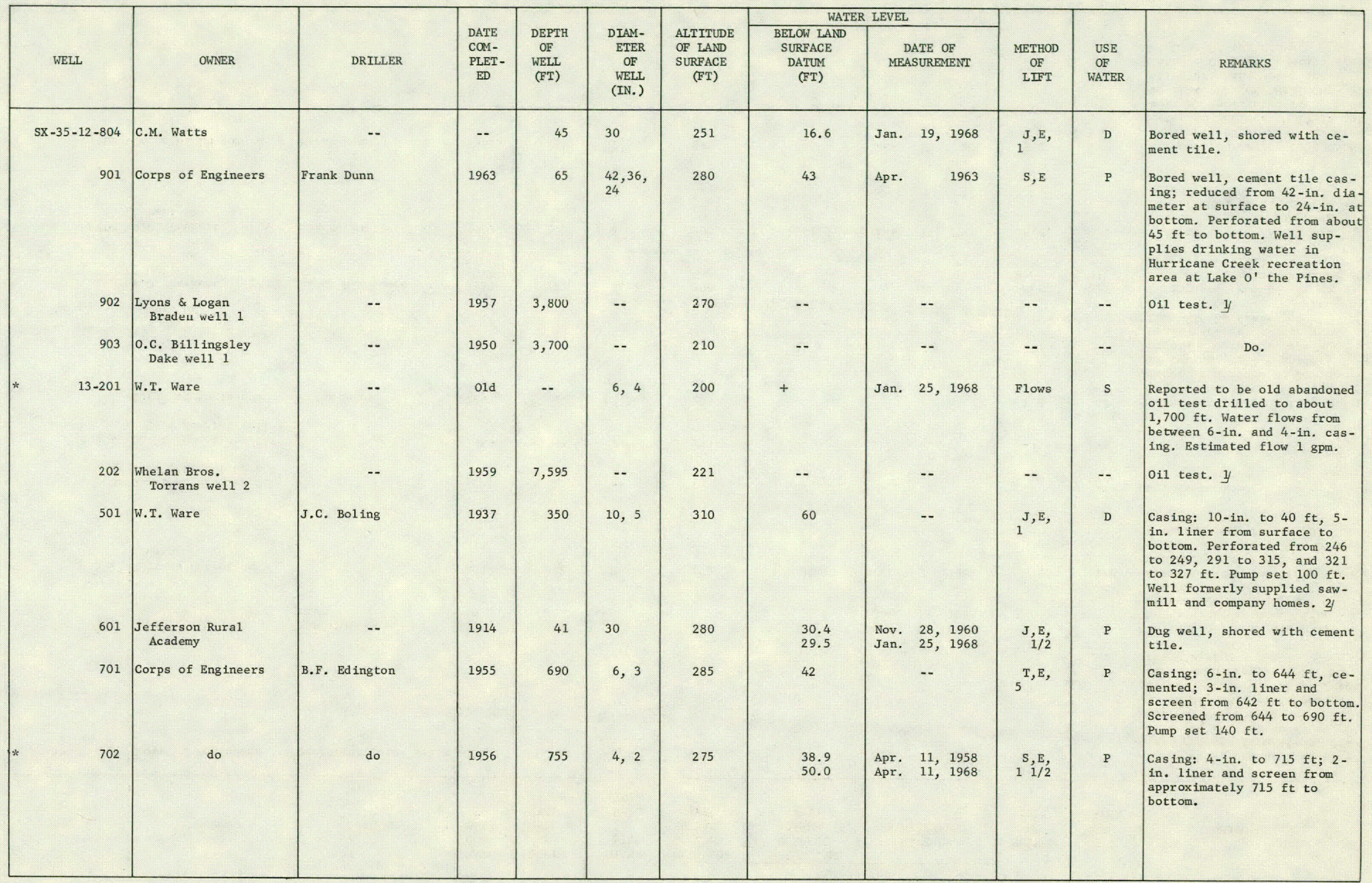

See footnotes at end of table. 
Table 7.-- Records of Wells and Springs in Cass and Marion Counties---Continued

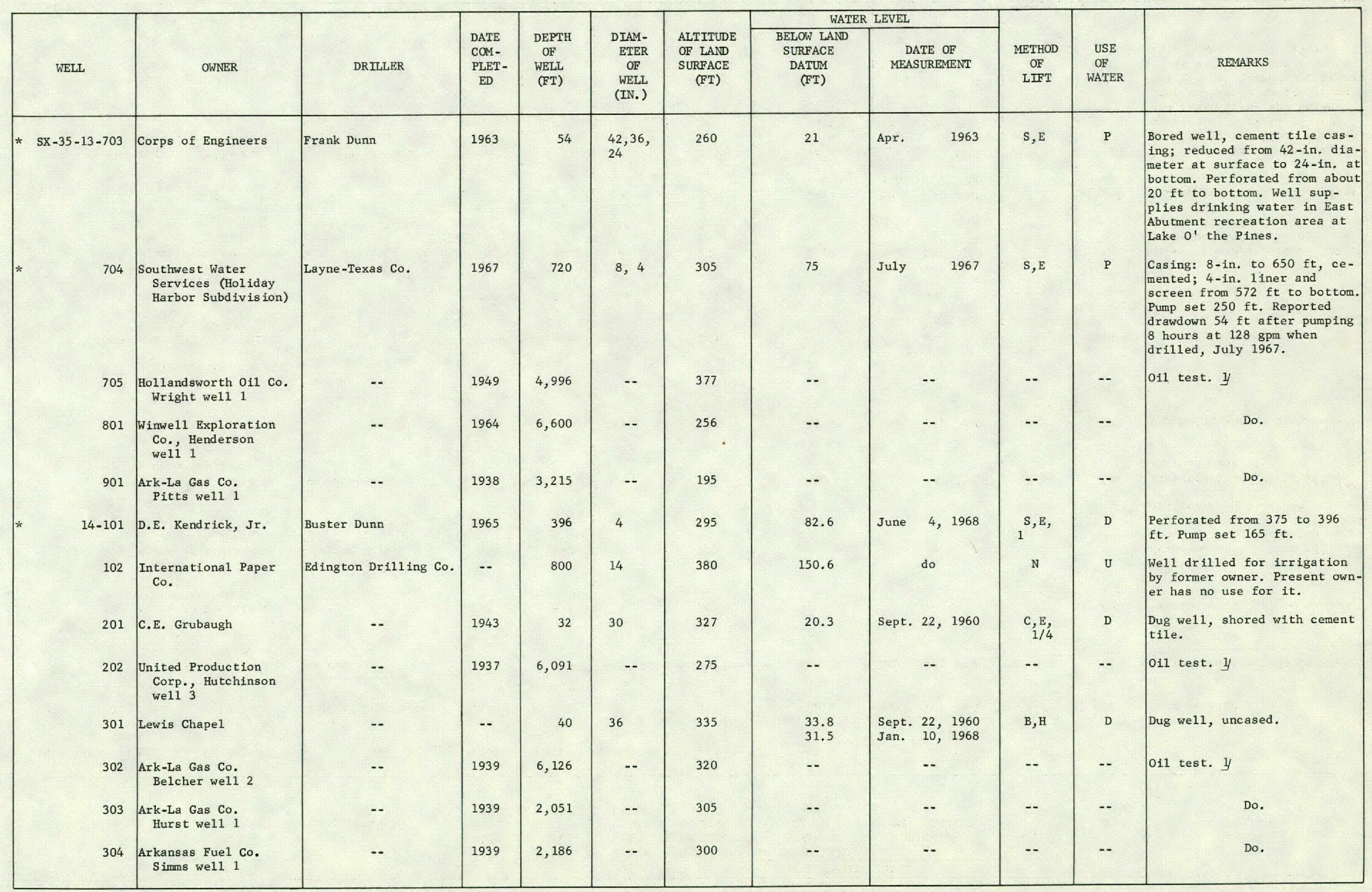

See footnotes at end of table. 
Table 7.-- Records of Wells and Springs in Cass and Marion Counties--Continued

\begin{tabular}{|c|c|c|c|c|c|c|c|c|c|c|c|c|}
\hline \multirow[b]{2}{*}{ WELL } & \multirow[b]{2}{*}{ OWNER } & \multirow[b]{2}{*}{ DRILLER } & \multirow[b]{2}{*}{$\begin{array}{l}\text { DATE } \\
\text { COM- } \\
\text { PLET- } \\
\text { ED }\end{array}$} & \multirow[b]{2}{*}{$\begin{array}{l}\text { DEPTH } \\
\text { OF } \\
\text { WELL } \\
\text { (FT) }\end{array}$} & \multirow[b]{2}{*}{$\begin{array}{l}\text { DIAM- } \\
\text { ETER } \\
\text { OF } \\
\text { WELL } \\
\text { (IN.) }\end{array}$} & \multirow[b]{2}{*}{$\begin{array}{l}\text { ALTITUDE } \\
\text { OF LAND } \\
\text { SURFACE } \\
\text { (FT) }\end{array}$} & \multicolumn{3}{|c|}{ WATER LEVEL } & \multirow[b]{2}{*}{$\begin{array}{l}\text { METHOD } \\
\text { OF } \\
\text { LIFT }\end{array}$} & \multirow[b]{2}{*}{$\begin{array}{l}\text { USE } \\
\text { OF } \\
\text { WATER }\end{array}$} & \multirow[b]{2}{*}{ REMARKS } \\
\hline & & & & & & & $\begin{array}{l}\text { BELOW LAND } \\
\text { SURFACE } \\
\text { DATUM } \\
\text { (FT) }\end{array}$ & & $\begin{array}{l}\text { ATE OF } \\
\text { SUREMENT }\end{array}$ & & & \\
\hline * $5 x-35-14-401$ & Southern Wood Co. & - & 1964 & 485 & 6 & 237 & 37.7 & June & 4, 1968 & $3^{\mathrm{S}, \mathrm{E}}$ & Ind & \\
\hline 501 & Arthur Arnold & $\begin{array}{l}\text { Rodessa Deep Water } \\
\text { We11 Co. }\end{array}$ & 1938 & 698 & 6 & 340 & 122.2 & Apr. & 16,1942 & $\mathrm{P}, \mathrm{E}$, & D & Pump set $196 \mathrm{ft}$. \\
\hline 502 & $\begin{array}{l}\text { Arkansas -Lou isiana } \\
\text { Chemical Corp., } \\
\text { wel1 } 4\end{array}$ & -- Bagley & 1941 & 815 & 6 & 285 & 130.0 & May & 31,1968 & $\mathrm{~N}$ & u & $\begin{array}{l}\text { Perforated from } 780 \text { to } 812 \\
\text { ft. }\end{array}$ \\
\hline 503 & $\begin{array}{l}\text { Arkansas -Louisiana } \\
\text { Chemical Corp., } \\
\text { we11 } 6\end{array}$ & -- & 1951 & 854 & 8 & 285 & -. & & - & $\mathrm{T}, \mathrm{E}$ & Ind & Standby well, seldom used. \\
\hline 504 & $\begin{array}{l}\text { Arkansas-Louisiana } \\
\text { Chemical Corp., } \\
\text { wel1 } 5\end{array}$ & B1evins Bros. & 1945 & 840 & 8 & 285 & -- & & -. & $G, J$ & Ind & $\begin{array}{l}\text { Screened from } 562 \text { to } 594 \text {, and } \\
1 / 28 \text { to } 762 \mathrm{CL} \text {. Measurcd pump } \\
\text { ing level } 150.0 \mathrm{ft} \text { below } 1 \text { and } \\
\text { surface, May } 31,1968 \text {. }\end{array}$ \\
\hline 505 & $\begin{array}{l}\text { Arkansas -Louis iana } \\
\text { Chemical Corp., } \\
\text { wel1 } 7\end{array}$ & -- Mayeaux & 1959 & 264 & 4 & 285 & -- & & -. & ${ }_{1}^{\mathrm{S}, \mathrm{E},}$ & Ind & $\begin{array}{l}\text { Screened from } 254 \text { to } 262 \mathrm{ft} \text {. } \\
\text { Pump set } 164 \mathrm{ft} \text {. }\end{array}$ \\
\hline 506 & Ha11 School & -- & 1935 & 30 & 30 & 282 & 9.5 & Mar. & 16,1960 & $\mathrm{~J}, \mathrm{E}$ & $P$ & $\begin{array}{l}\text { Dug well, shored with cement } \\
\text { tile. }\end{array}$ \\
\hline 507 & $\begin{array}{l}\text {-- Stewart } \\
\text { Brown Estate well } 1\end{array}$ & - & 1945 & 7,209 & -- & 350 & -- & & -- & - & - & oil test. y \\
\hline 508 & $\begin{array}{l}\text { Arkansas Fuel oil Co. } \\
\text { Barnes well } 1\end{array}$ & -. & 1939 & 6,086 & -- & 285 & -- & & -- & - & $-\cdot$ & Do. \\
\hline 509 & $\begin{array}{l}\text { Arkansas Fuel oil Co. } \\
\text { Cromer well } 1\end{array}$ & -- & 1939 & 5,967 & -- & 221 & -- & & -- & - & -- & Do. \\
\hline 701 & Blackburn Syrup Co. & W.C. Barnwel1 & 1955 & 850 & 6 & 235 & 51.7 & Mar. & 23,1960 & $\mathrm{~s}, \mathrm{E}$ & Ind & $\begin{array}{l}\text { Measured pumping leve1 } 112.5 \\
\text { ft below 1and surface, } \\
\text { January 25, 1968. }\end{array}$ \\
\hline 702 & do & -- & 1940 & 40 & -- & 235 & $\begin{array}{l}24.1 \\
37.7\end{array}$ & $\begin{array}{l}\text { Mar. } \\
\text { Jan. }\end{array}$ & $\begin{array}{ll}23, & 1960 \\
25, & 1968\end{array}$ & $\mathrm{~T}, \mathrm{E}$ & Ind & Dug wel1, shored with bricks. \\
\hline 703 & $\begin{array}{l}\text { City of Jefferson } \\
\text { well } 2\end{array}$ & Layne-Texas Co. & 1947 & 797 & $\frac{13,12}{6}$ & 215 & $\begin{array}{l}45 \\
57.4 \\
27.0\end{array}$ & $\begin{array}{l}\text { Apr. } \\
\text { May } \\
\text { Nov. }\end{array}$ & $\begin{array}{rr} & 1947 \\
8, & 1961 \\
20, & 1967\end{array}$ & $40^{T, E}$ & $\mathrm{U}$ & $\begin{array}{l}\text { Casing: } 13-\text { in. to } 364 \mathrm{ft} \text {, ce- } \\
\text { mented; } 12 \text {-in. } 1 \text { iner from ap } \\
\text { proximately } 364 \text { to } 703 \mathrm{ft} \text {, } \\
\text { and } 6 \text {-in. liner and screen } \\
\text { from } 585 \mathrm{ft} \text { to bottom. Pump } \\
\text { set } 200 \mathrm{ft} \text {. Measured drawdown } \\
79 \mathrm{ft} \text { after pumping } 2 \text { hours } \\
\text { at } 348 \mathrm{gpm} \text {, May } 8,1961 .\end{array}$ \\
\hline
\end{tabular}

See footnotes at end of table. 
Table 7.-- Records of Wells and Springs in Cass and Marion Counties--Continued

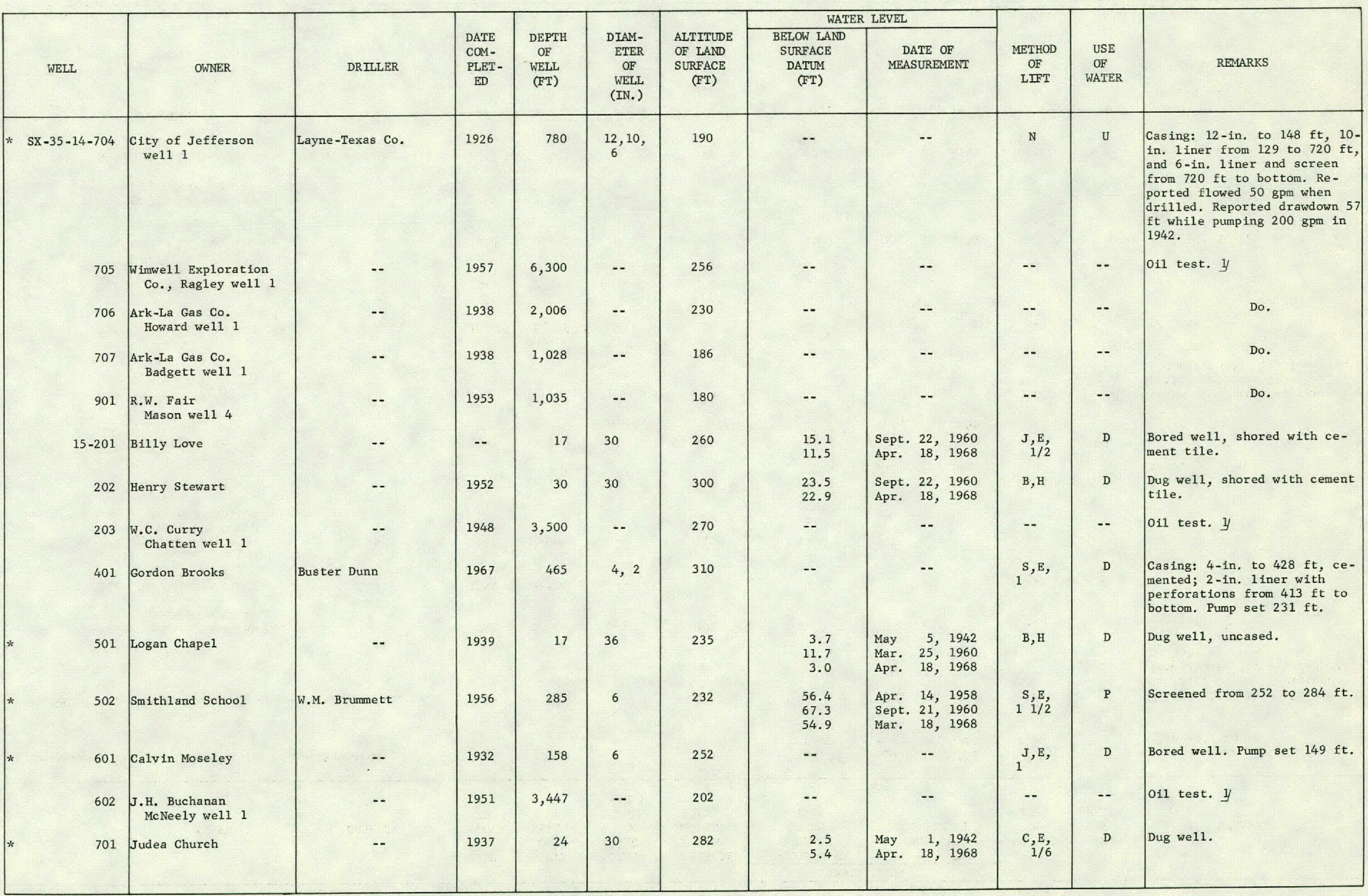

See footnotes at end of table. 
Table 7.-- Records of Wells and Springs in Cass and Marion Counties--Continued

\begin{tabular}{|c|c|c|c|c|c|c|c|c|c|c|c|c|}
\hline \multirow[b]{2}{*}{ WELL } & \multirow[b]{2}{*}{ OWNER } & \multirow[b]{2}{*}{ DRILLER } & \multirow[b]{2}{*}{$\begin{array}{l}\text { DATE } \\
\text { COM- } \\
\text { PLET- } \\
\text { ED }\end{array}$} & \multirow[b]{2}{*}{$\begin{array}{l}\text { DEPTH } \\
\text { OF } \\
\text { WELL } \\
\text { (FT) }\end{array}$} & \multirow[b]{2}{*}{$\begin{array}{l}\text { DIAM- } \\
\text { ETER } \\
\text { OF } \\
\text { WELL } \\
\text { (IN.) }\end{array}$} & \multirow[b]{2}{*}{$\begin{array}{l}\text { ALTITUDE } \\
\text { OF IAND } \\
\text { SURFACE } \\
\text { (FT) }\end{array}$} & \multicolumn{3}{|c|}{ WATER LEVEL } & \multirow[b]{2}{*}{$\begin{array}{l}\text { METHOD } \\
\text { OF } \\
\text { LIFT }\end{array}$} & \multirow[b]{2}{*}{$\begin{array}{l}\text { USE } \\
\text { OF } \\
\text { WATER }\end{array}$} & \multirow[b]{2}{*}{ REMARKS } \\
\hline & & & & & & & $\begin{array}{l}\text { BELOW LAND } \\
\text { SURFACE } \\
\text { DATUM } \\
\text { (FT) }\end{array}$ & $\begin{array}{r}\text { DA } \\
\text { MEAS }\end{array}$ & $\begin{array}{l}\text { ATE OF } \\
\text { SUREMENT }\end{array}$ & & & \\
\hline Sx $-35-15-702$ & Robert Pepper & -- Rayborne & 1947 & 325 & 6 & 305 & $\begin{array}{l}104.7 \\
105.2 \\
106.9\end{array}$ & $\begin{array}{l}\text { Apr. } \\
\text { Sept. } \\
\text { Apr. }\end{array}$ & $\begin{array}{ll}10, & 1958 \\
21, & 1960 \\
18, & 1968\end{array}$ & $1_{1}^{\mathrm{J}, \mathrm{E}}$ & D & $\begin{array}{l}\text { Cas ing: } 6-\text { in. to } 136 \mathrm{ft} . \\
\text { Pump set } 120 \mathrm{ft} \text {. }\end{array}$ \\
\hline 801 & Tex-Mex Drilling Co. & White Drilling Co. & 1965 & 350 & 3 & 250 & 61.4 & Apr. & 18,1968 & $\mathrm{~N}$ & u & $\begin{array}{l}\text { Wel1 drilled for oil; now } \\
\text { drilling water. Perforated } \\
\text { from } 150 \text { to } 169 \mathrm{ft} \text {, and } 315 \\
\text { to } 350 \mathrm{ft} \text {. }\end{array}$ \\
\hline 802 & $\begin{array}{l}\text { Barnwell Drilling Co., } \\
\text { lowherd well } 1\end{array}$ & -- & 1957 & 2,507 & -- & 201 & - & & -- & -- & -- & Oil test. $y$ \\
\hline 901 & $\begin{array}{l}\text { The Chicago Corp. } \\
\text { Rowell well } 1\end{array}$ & -- & 1954 & 6,050 & -- & 175 & -- & & -- & -- & - & Do. \\
\hline $16-201$ & $\begin{array}{l}\text { Ryan Consolidated } \\
\text { Petroleum Corp, } \\
\text { Schluter well i }\end{array}$ & -- & 1947 & 3,008 & -- & 260 & -- & & -- & -- & $\cdots$ & Do. \\
\hline 401 & Felix Spencer & -- & 1946 & 23 & 30 & 247 & $\begin{array}{l}19.0 \\
17.6\end{array}$ & $\begin{array}{l}\text { Sept. } \\
\text { Jan. }\end{array}$ & $\begin{array}{ll}21, & 1960 \\
29, & 1968\end{array}$ & $\mathrm{~B}, \mathrm{H}$ & D & $\begin{array}{l}\text { Dug well, shored with cement } \\
\text { tile. }\end{array}$ \\
\hline 402 & F.C. Clements & -- & 1935 & 28 & 36 & 270 & $\begin{array}{l}15.6 \\
13.9\end{array}$ & $\begin{array}{l}\text { Sept. } \\
\text { Jan. }\end{array}$ & $\begin{array}{ll}20, & 1960 \\
29, & 1968\end{array}$ & $\mathrm{P}, \mathrm{H}$ & D & Dug wel1, uncased. \\
\hline 403 & Davis \& Smith & -- & -- & 509 & 7 & 305 & -- & & -- & $5^{P, E}$ & Ind & $\begin{array}{l}\text { Cased to bottom, cemented; } \\
\text { perforated from } 385 \text { to } 399 \text {, } \\
\text { and } 434 \text { to } 437 \mathrm{ft} \text {. Pump set } \\
380 \mathrm{ft} \text {. }\end{array}$ \\
\hline 501 & $\begin{array}{l}\text { Hollondsworth Drilling } \\
\text { Co., Hartzo well } 1\end{array}$ & -- & 1940 & 2,535 & -- & 230 & -- & & -- & - & -- & oil test. y \\
\hline 502 & $\begin{array}{l}\text { H.W. Snowden } \\
\text { Watts we11 } 1\end{array}$ & -- & 1946 & 2,561 & -- & 200 & - & & -- & - & - & Do. \\
\hline 701 & Allen Livingston & -- & 1950 & 100 & 4 & 177 & 10.7 & Jan. & 29,1968 & $\mathrm{~s}, \mathrm{E}$, & D & Pump set $35 \mathrm{ft}$. \\
\hline 702 & $\begin{array}{l}\text { M.E. Merriman, et al. } \\
\text { Dumider wel1 } 1\end{array}$ & -- & 1960 & 2,310 & -- & 204 & -- & & -- & - & - & 0 il test. $y$ \\
\hline 801 & Allen Livingston & Texas Highway Dept. & 1947 & 485 & 4 & 240 & 65.3 & Jan. & 29,1968 & $\mathrm{~S}, \mathrm{E}$, & D & $\begin{array}{l}\text { Cased to } 84 \mathrm{ft} \text {, open hole } \\
\text { from } 84 \mathrm{ft} \text { to bottom. }\end{array}$ \\
\hline 802 & W.G. Davis & -- & -- & 202 & 6 & 265 & 101.3 & Apr. & 10,1958 & $\mathrm{~J}, \mathrm{E}$, & D & \\
\hline 803 & $\begin{array}{l}\text { Amerada Petroleum } \\
\text { Corp., Gray well } 1\end{array}$ & -- & 1961 & 2,281 & -- & 247 & - & & - & -- & - & 0 il test. $y$ \\
\hline
\end{tabular}

See footnotes at end of table. 
Table 7..- Records of Wells and Springs in Cass and Marion Counties--Continued

\begin{tabular}{|c|c|c|c|c|c|c|c|c|c|c|c|c|}
\hline \multirow[b]{2}{*}{ WELL } & \multirow[b]{2}{*}{ OWNER } & \multirow[b]{2}{*}{ DRILLER } & \multirow[b]{2}{*}{$\begin{array}{l}\text { DATE } \\
\text { COM- } \\
\text { PLET- } \\
\text { ED }\end{array}$} & \multirow[b]{2}{*}{$\begin{array}{l}\text { DEPTH } \\
\text { OF } \\
\text { WELL } \\
\text { (FT) }\end{array}$} & \multirow[b]{2}{*}{$\begin{array}{l}\text { DIAM- } \\
\text { ETER } \\
\text { OF } \\
\text { WELL } \\
\text { (IN.) }\end{array}$} & \multirow[b]{2}{*}{$\begin{array}{l}\text { ALTTTUDE } \\
\text { OF LAND } \\
\text { SURFACE } \\
\text { (FT) }\end{array}$} & \multicolumn{3}{|c|}{ WATER LEVEL } & \multirow[b]{2}{*}{$\begin{array}{l}\text { METHOD } \\
\text { OF } \\
\text { LIFT }\end{array}$} & \multirow[b]{2}{*}{$\begin{array}{l}\text { USE } \\
\text { OF } \\
\text { WATER }\end{array}$} & \multirow[b]{2}{*}{ REMARKS } \\
\hline & & & & & & & $\begin{array}{l}\text { BELOW LAND } \\
\text { SURFACE } \\
\text { DATTM } \\
\text { (FT) }\end{array}$ & $\begin{array}{r}\text { DAT } \\
\text { MEASU }\end{array}$ & $\begin{array}{l}\text { TE OF } \\
\text { UREMENT }\end{array}$ & & & \\
\hline SX $-35-16-804$ & $\begin{array}{l}\text { J.H. Holt } \\
\text { Gray well } 2\end{array}$ & $\cdots$ & 1947 & 3,195 & -- & 203 & -- & & -- & $-\cdot$ & $\cdots$ & oil test. I \\
\hline 805 & $\begin{array}{l}\text { J.W. Reneau } \\
\text { Davis well } 1\end{array}$ & $-\cdot$ & 1947 & 2,700 & - & 260 & -- & & -- & -- & -- & Do. \\
\hline $20-201$ & $\begin{array}{l}\text { Jackson Community } \\
\text { Center }\end{array}$ & -- & old & 19 & 30 & 285 & $\begin{array}{r}10.8 \\
12.3 \\
9.4\end{array}$ & $\begin{array}{l}\text { Mar. } \\
\text { Sept. } \\
\text { Apr. }\end{array}$ & $\begin{array}{ll}17, & 1942 \\
28, & 1960 \\
11, & 1968\end{array}$ & N & $\mathrm{u}$ & $\begin{array}{l}\text { Dug well, shored with cement } \\
\text { tile. }\end{array}$ \\
\hline 202 & M.K. Knight & Edington Drilling Co. & 1960 & 679 & 8,4 & 300 & 57.8 & Sept. 2 & 28,1960 & $10^{S, E}$ & $\mathrm{P}$ & $\begin{array}{l}\text { Casing: } 8-\text { in. to } 618 \mathrm{ft} \text {, ce- } \\
\text { mented; } 4-\text { in. liner and } \\
\text { screen from } 577 \mathrm{ft} \text { to bottom. } \\
\text { Pump set } 250 \mathrm{ft} \text {. }\end{array}$ \\
\hline 203 & $\begin{array}{l}\text { Helmrich \& Payne } \\
\text { Hook we11 } 1\end{array}$ & -- & 1940 & 5,004 & $\cdots$ & 270 & -- & & -- & -- & -- & $0 i 1$ test. $y$ \\
\hline 301 & Macedonia Schoo1 & $-\cdot$ & 1947 & 28 & 30 & 275 & $\begin{array}{l}19.7 \\
20.6\end{array}$ & $\begin{array}{l}\text { Mar. } \\
\text { Apr. }\end{array}$ & $\begin{array}{l}21,1960 \\
11,1968\end{array}$ & $\mathrm{~J}, \mathrm{E}$, & $\mathrm{P}$ & $\begin{array}{l}\text { Dug well, shored with cement } \\
\text { tile. }\end{array}$ \\
\hline $21-101$ & $\begin{array}{l}\text { LeCuno Oil Co. } \\
\text { Benton well } 1\end{array}$ & -. & 1956 & 7,115 & -- & 203 & -- & & -- & -- & -- & $0 i 1$ test. $y$ \\
\hline 201 & $\begin{array}{l}\text { Carter-Jones Drilling } \\
\text { Co., Whelon well } 1\end{array}$ & -- & 1956 & 6,987 & -- & 207 & -- & & -- & -- & -- & Do. \\
\hline 202 & $\begin{array}{l}\text { Bobby Manziel } \\
\text { Whelon we11 B-1 }\end{array}$ & -- & 1956 & 6,129 & -- & 193 & -- & & -- & $\cdot-$ & -- & Do. \\
\hline 301 & C.A. Arnold & Mustang Drilling Co. & 1963 & 350 & 4 & 345 & 150 & Feb. 2 & 23,1963 & $2^{S, E}$ & D & $\begin{array}{l}\text { Screen from } 318 \text { to } 348 \mathrm{ft} \text {. } \\
\text { Pump set } 205 \mathrm{ft} \text {. }\end{array}$ \\
\hline 302 & $\begin{array}{l}\text { Ark-La Gas Co. } \\
\text { Moseley weli } 1\end{array}$ & -- & 1938 & 6,160 & - & 187 & -- & & -- & $-\cdot$ & -- & 011 test. $y$ \\
\hline 501 & New $Z$ ion Church & -. & 1933 & 32 & 30 & 252 & $\begin{array}{r}11.2 \\
17.0 \\
6.8\end{array}$ & $\begin{array}{l}\text { Mar. } \\
\text { Sept. } \\
\text { Apr. }\end{array}$ & $\begin{array}{ll}17, & 1942 \\
29, & 1960 \\
11, & 1968\end{array}$ & $\mathrm{~J}, \mathrm{E}$, & D & $\begin{array}{l}\text { Dug well, shored with cement } \\
\text { tile. }\end{array}$ \\
\hline $22-101$ & Dan Lester & $-\cdot$ & 1968 & 160 & 4 & 205 & 20.7 & Apr. & 11, 1968 & $\mathrm{~S}, \mathrm{E}$, & $\mathrm{s}$ & \\
\hline $24-101$ & Lewis Luttrell & Shirley-Will iamson & 1946 & 300 & 4 & 200 & 22.1 & Jan. 2 & 29,1968 & $\begin{array}{l}\mathrm{J}, \mathrm{E}, \\
\mathrm{I} / 2\end{array}$ & D & Pump set $84 \mathrm{ft}$. \\
\hline 201 & T.W. Allen & -. & 1941 & 30 & 30 & 240 & 19.5 & Sept. 2 & 20,1960 & $\mathrm{~J}, \mathrm{E}$ & D & $\begin{array}{l}\text { Dug well, shored with clay } \\
\text { tile. }\end{array}$ \\
\hline 202 & w.G. Allen & -- & 1957 & 190 & 4 & 235 & 60.4 & Sept. 2 & 20,1960 & $\mathrm{~s}, \mathrm{E}$ & D & Casing: 4 -in. to $90 \mathrm{ft}$. \\
\hline
\end{tabular}

See footnotes at end of table. 
Table 7..- Records of Wells and Springs in Cass and Marion Counties--Continued

\begin{tabular}{|c|c|c|c|c|c|c|c|c|c|c|c|}
\hline \multirow[b]{2}{*}{ WELL } & \multirow[b]{2}{*}{ OWNER } & \multirow[b]{2}{*}{ DRTLLER } & \multirow[b]{2}{*}{$\begin{array}{l}\text { DATE } \\
\text { COM- } \\
\text { PLET- } \\
\text { ED }\end{array}$} & \multirow[b]{2}{*}{$\begin{array}{l}\text { DEPTH } \\
\text { OF } \\
\text { WEL,L } \\
\text { (FT) }\end{array}$} & \multirow[b]{2}{*}{$\begin{array}{c}\text { DIAM- } \\
\text { ETER } \\
\text { OF } \\
\text { WELL } \\
\text { (IN.) }\end{array}$} & \multirow[b]{2}{*}{$\begin{array}{c}\text { ALTITUDE } \\
\text { OF LAND } \\
\text { SURFACE } \\
\text { (FT) }\end{array}$} & \multicolumn{2}{|c|}{ WATER LEVEL } & \multirow[b]{2}{*}{$\begin{array}{l}\text { METHOD } \\
\text { OF } \\
\text { LIFT }\end{array}$} & \multirow[b]{2}{*}{$\begin{array}{l}\text { USE } \\
\text { OF } \\
\text { WATER }\end{array}$} & \multirow[b]{2}{*}{ REMARKS } \\
\hline & & & & & & & $\begin{array}{l}\text { BELOW LAND } \\
\text { SURFACE } \\
\text { DATUM } \\
\text { (FT) }\end{array}$ & $\begin{array}{c}\text { DATE OF } \\
\text { MEASUREMENT }\end{array}$ & & & \\
\hline $\mathrm{Sx}-35-24-203$ & $\begin{array}{l}\text { H.M. Hammer } \\
\text { Poole well } 1\end{array}$ & -. & 1947 & 2,690 & -- & 202 & -- & -- & - & -- & Oil test. y \\
\hline 501 & Mrs. W.E. Haggard & -. & -- & Spring & -- & 205 & + & Jan. 29,1968 & Flows & D & Estimated flow $5 \mathrm{gpm}$. \\
\hline
\end{tabular}

1 Electric $\log$ in files of U.S. Geological Survey, Austin, Texas, and Texas Water Development Board, Austin, Texas.

For drillers logs of wells, see Table 8 . 
Table 8.-Drillers' Logs of Wells in Cass and Marion Counties

$\begin{array}{cc}\text { THICKNESS } & \text { DEPTH } \\ \text { (FEET) } & \text { (FEET) }\end{array}$

Cass County

\section{Well DB-16-53-106}

Owner: Shell Oil Co.

Driller: Layne-Texas Co.

Clay, red

Sand and clay

Clay

Sand

Clay

Sand and clay layers

Shale, gray, hard, sandy

Sand, gray, and streaks of

shale

Shale, lignite, and thin sand layers

Sand, fine, grav, and sandy shale

Shale and lignite

Sand

Shale

Sand

Rock and hard shale layers

Sand

Shale and sandy shale

Sand

Shale and sandy shale

Shale

Sand and shale layers

Shale and sandy shale

Sand (cut good)

Shale

Sand (cut good)

Shale

Shale, sandy

Shale

Well DB-16-54-403

Owner: City of Douglassville. Driller: Edington Drilling Co.

Surface

Clay
THICKNESS

(FEET)

DEPTH

(FEET)

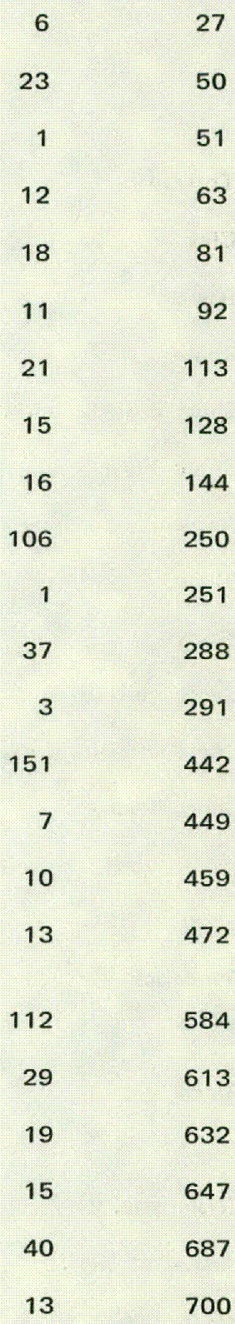

\section{Well DB-16-59-901}

Owner: City of Hughes Springs. Driller: Layne-Texas Co.

Shale, sandy

10

Shale

25

Shale, sandy

118

Shale and lignite

224

Sand and shale

281

Sand, good

313

Rock

314

Sand

353

Shale, sandy

359 
Table 8.-Drillers' Logs of Wells in Cass and Marion Counties-Continued

\section{THICKNESS DEPTH \\ (FEET) \\ (FEET)}

Well DB-16-62-701

Owner: City of Linden. Driller: Layne-Texas Co.

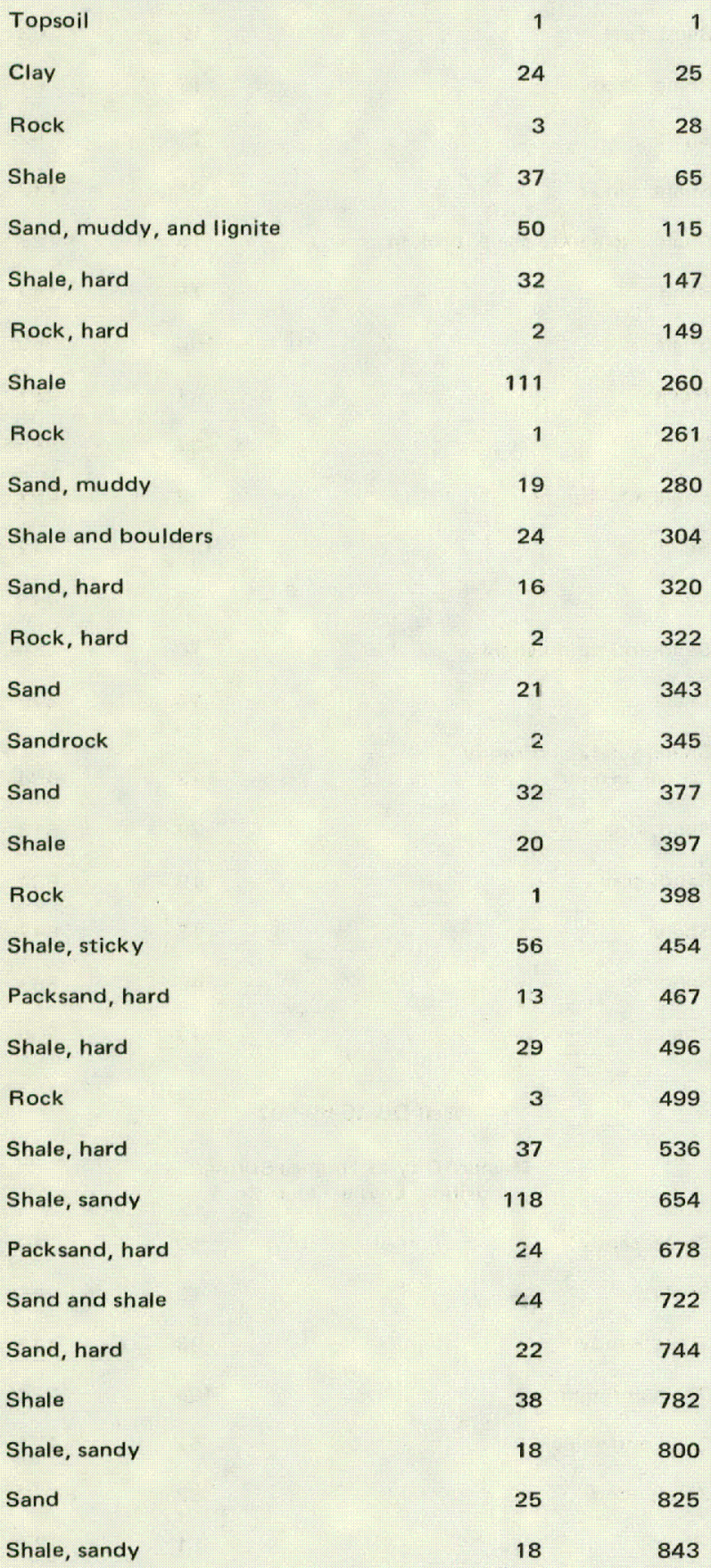

Well DB-16-63-201

Owner: City of Atlanta, well 2. Driller: Layne-Texas Co.

Topsoil

Clay, sandy

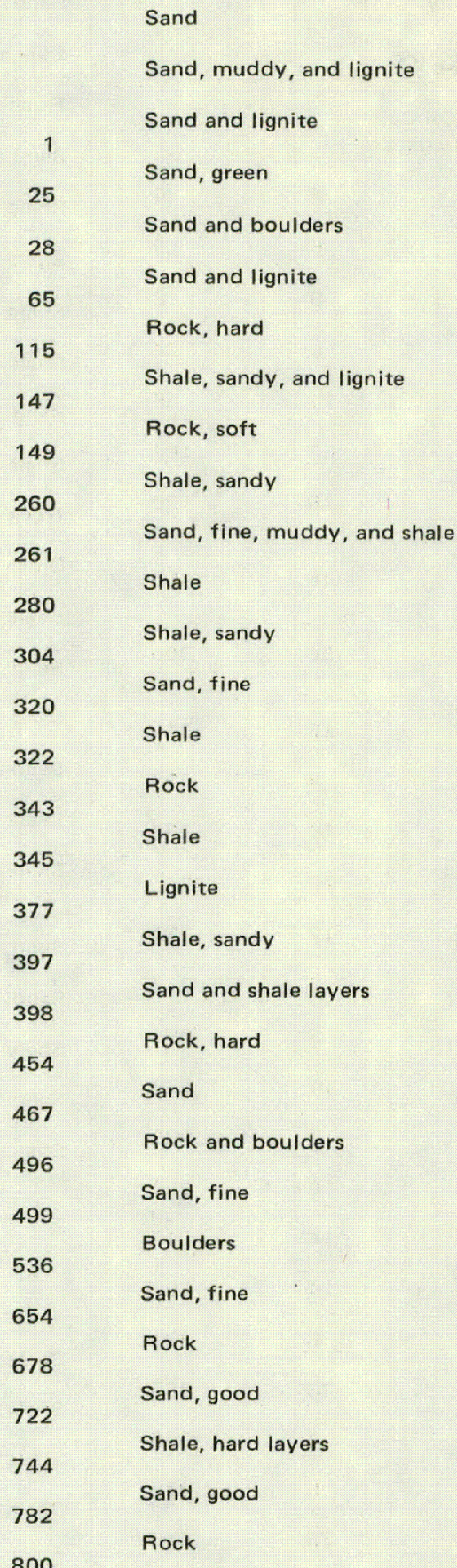

THICKNESS DEPTH

(FEET) (FEET)

\begin{tabular}{|c|c|}
\hline 1 & 29 \\
\hline 65 & 94 \\
\hline 74 & 168 \\
\hline 29 & 197 \\
\hline 4 & 201 \\
\hline 77 & 278 \\
\hline $1 / 2$ & $2781 / 2$ \\
\hline $54 \frac{1}{2}$ & 333 \\
\hline 2 & 335 \\
\hline 40 & 375 \\
\hline 63 & 438 \\
\hline 12 & 450 \\
\hline 20 & 470 \\
\hline 42 & 512 \\
\hline 16 & 528 \\
\hline 1 & 529 \\
\hline 54 & 583 \\
\hline 10 & 593 \\
\hline 56 & 649 \\
\hline 37 & 686 \\
\hline 1 & 687 \\
\hline 8 & 695 \\
\hline 10 & 705 \\
\hline 33 & 738 \\
\hline 1 & 739 \\
\hline 28 & 767 \\
\hline 2 & 769 \\
\hline 32 & 801 \\
\hline 7 & 808 \\
\hline 35 & 843 \\
\hline 1 & \\
\hline
\end{tabular}

Well DB-35-04-803

Owner: City of Avinger. Driller: Edington Drilling Co.

$\begin{array}{lll}\text { Surface } & 15 & 15 \\ \text { Shale } & 22 & 37 \\ \text { Sand } & 21 & 58 \\ \text { Shale } & 21 & 79\end{array}$


Table 8.-Drillers' Logs of Wells in Cass and Marion Counties-Continued

$\begin{array}{cc}\text { THICKNESS } & \text { DEPTH } \\ \text { (FEET) } & \text { (FEET) }\end{array}$

Well DB-35-04-803-Continued

Sand
Shale and sand streaks
Sand
Shale
Sand
Shale
Sand
Shale
Sand and shale streaks
Sand
Rock
Sand
Shale

\section{6}

41

13

58

20

5

6

33

5

35

$1 / 2$

$22 \frac{1}{2}$

79
85

126

139

197

217

222

228

261

266

301

$301 \frac{1}{2}$

324

403

\section{Well SX-35-13-501}

Owner: W. T. Ware.

Driller: J. C. Boling.

Clay, yellow

Surface, water

Shale, black

Lignite

Sand, water

Shale, gray

Sand, water

Shale, blue

Sand, water

Shale, blue
THICKNESS

(FEET)

Marion County

DEPTH

(FEET)

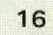

16

4

20

220

240

$5 \quad 245$

$4 \quad 249$

$41 \quad 290$

$25 \quad 315$

$5 \quad 320$

$7 \quad 327$

23

350 
Table 9.--Chemical Analyses of Water From Wells and Springs in Cass and Marion Counties

(Analyses given are in milligrams per 1iter except percent sodium, sodium-adsorption ratio, residual sodium carbonate, specific conductance, temperature, and pH.)

\begin{tabular}{|c|c|c|c|c|c|c|c|c|c|c|c|c|c|c|c|c|c|c|c|c|c|}
\hline WELL & $\begin{array}{c}\text { DEPTH } \\
\text { OR } \\
\text { PRODUCING } \\
\text { INTERVAL } \\
\text { (FT) }\end{array}$ & $\begin{array}{l}\text { DATE OF } \\
\text { COLLECTION }\end{array}$ & $\begin{array}{l}\text { SILICA } \\
\left(\mathrm{SiO}_{2}\right)\end{array}$ & $\begin{array}{l}\text { IRON } \\
(\mathrm{Fe})\end{array}$ & $\begin{array}{l}\text { CAL- } \\
\text { CIUM } \\
\text { (Ca) }\end{array}$ & $\begin{array}{l}\text { MAGNE- } \\
\text { SIUM } \\
\text { (Mg) }\end{array}$ & $\begin{array}{c}\text { SODIUM } \\
(\mathrm{Na})\end{array}$ & $\begin{array}{l}\text { POTAS- } \\
\text { SIUM } \\
\text { (K) }\end{array}$ & $\begin{array}{l}\text { BICAR- } \\
\text { BONATE } \\
\left(\mathrm{HCO}_{3}\right)\end{array}$ & $\begin{array}{l}\text { SUL- } \\
\text { FATE } \\
\left(\mathrm{SO}_{4}\right)\end{array}$ & $\begin{array}{l}\text { CHLO- } \\
\text { RIEE } \\
\text { (C1) }\end{array}$ & $\begin{array}{l}\text { FLUO- } \\
\text { RIDE } \\
\text { (F) }\end{array}$ & $\begin{array}{l}\text { NI- } \\
\text { TRATE } \\
\text { (NOO3) }\end{array}$ & $\begin{array}{l}\text { DIS- } \\
\text { SOLVED } \\
\text { SOLIDS }\end{array}$ & \begin{tabular}{|l} 
HARD- \\
$\mathrm{NESS}$ \\
$\mathrm{AS}$ \\
$\mathrm{CaCO}_{3}$
\end{tabular} & \begin{tabular}{|l} 
PER- \\
CENT \\
SO- \\
DIUM
\end{tabular} & \begin{tabular}{|c|} 
SOD IUM \\
ADSORP- \\
TION \\
RATIO \\
(SAR)
\end{tabular} & $\begin{array}{l}\text { RESI- } \\
\text { DUAL } \\
\text { SODIUM } \\
\text { CAR- } \\
\text { BONATE } \\
\text { (RSC) }\end{array}$ & $\begin{array}{l}\text { SPECIFIC } \\
\text { CONDUCT - } \\
\text { ANCE } \\
\text { (MTCROMHOS } \\
\text { AT } 25^{\circ} \mathrm{C} \text { ) }\end{array}$ & $\begin{array}{l}\text { TEMPER- } \\
\text { ATURE }\end{array}$ & $\mathrm{pH}$ \\
\hline
\end{tabular}

\begin{tabular}{|c|c|c|c|c|c|c|c|c|c|c|c|c|c|c|c|c|c|c|c|c|c|c|c|}
\hline DB $-16-47-501$ & & 115 & May & 29,1968 & 30 & 0.11 & 30 & 0.1 & 2.0 & 0.4 & 88 & 6.4 & 2.3 & 0.0 & 0.1 & 114 & 75 & 5 & 0.1 & 0.00 & 163 & $-\cdot$ & 7.3 \\
\hline $48-701$ & & 39 & Dec. & 13,1941 & -- & -- & 2.4 & 2.7 & $2.8 *$ & -- & 12 & 2 & 7.0 & .2 & 1.0 & 24 & 17 & -. & -. & - & - & -- & -- \\
\hline $51-601$ & & 275 & May & $.28,1968$ & 9.2 & .09 & 8.5 & 1.8 & 124 & 2.9 & 241 s & 85 & 12 & .5 & 2.6 & 396 & 28 & 89 & 10 & 3.38 & 613 & -- & 8.3 \\
\hline 602 & & 16 & Dec. & 9,1941 & - & -- & a) & 7.3 & $14 \%$ & -- & 31 & 20 & 10 & - & 1.0 & Кв & 31 & -- & -- & -- & - & -- & $\cdots$ \\
\hline $52-101$ & & 24 & & do & -- & -- & 2.4 & 2.7 & $3.7 *$ & -- & 6 & 2 & 9.0 & -- & 7.0 & 30 & 17 & -- & - & - & - & -- & -- \\
\hline 301 & 232. & 295 & May & 28,1968 & 9.4 & -. & 12 & 1.9 & 132 & 2.0 & 306 & 32 & 29 & .4 & 2.2 & 371 & 38 & 88 & 9.3 & 4.26 & 642 & 21 & 7.7 \\
\hline 501 & 563. & 593 & Mar. & 14,1968 & 12 & .09 & 1.8 & .3 & 235 & 1.2 & 420 & 18 & 114 & .6 & .0 & 590 & 6 & 99 & 42 & 6.77 & 1,020 & 23 & 8.2 \\
\hline 701 & & 25 & Dec. & 9,1941 & -. & -- & .4 & 3.9 & $5.3 *$ & -. & 6 & 12 & 2.5 & -. & 9.0 & 36 & 17 & -- & - & -. & $\cdots$ & -. & -. \\
\hline $53-101$ & & 50 & & do & - & -- & so & 49 & 148 * & -- & 214 & 49 & 298 & -. & 3.0 & 702 & 326 & -- & $-\cdot$ & -- & -- & $-\cdot$ & - \\
\hline 102 & & 49 & Dec. & 10,1941 & -. & -- & 128 & 118 & $46 *$ & - & 317 & 23 & 438 & .4 & 2.0 & 911 & 803 & - & - & - & $-\cdot$ & -- & - \\
\hline 103 & & 16 & & do & -- & -- & 46 & 61 & $65 *$ & -- & 31 & 300 & 120 & .3 & 2.0 & 609 & 368 & -- & -- & -- & $-\cdot$ & -- & - \\
\hline 104 & $\begin{array}{l}\text { 257- } \\
305-\end{array}$ & $\begin{array}{l}267 \\
395\end{array}$ & Mar. & 5, 1968 & 12 & .02 & 16 & 2.9 & 140 & 2.9 & 250 & 52 & 68 & .3 & 3.7 & 421 & 52 & 85 & 8.4 & 3.06 & 722 & 21 & 7.4 \\
\hline 201 & & 33 & Dec. & 10,1941 & -. & $\cdots$ & 30 & 52 & $212 *$ & -- & 55 & 236 & 323 & .1 & 1.5 & 882 & 287 & $-\cdot$ & $-\cdot$ &.- & -- & -- & -- \\
\hline 601 & & 28 & & do & -. & -- & 2.0 & 1.5 & 9.7 * & -- & 12 & 2 & 6.0 & -- & 14 & 41 & 11 & -- & $y$ & -- & - & - & - \\
\hline 901 & & 35 & & do & -- & -- & a) & 1.2 & 4.6 * & - & 0 & 2 & 3.0 & -. & 11 & 22 & 5 & -- & -. & -. & - & -. & $-\cdot$ \\
\hline 903 & & 108 & May & 28,1968 & 25 & 11 & 9.8 & 3.9 & 6.1 & 2.0 & 40 & 16 & 3.9 & .0 & .1 & 87 & 40 & 24 & .4 & .00 & 121 & 20 & 7.0 \\
\hline $54-202$ & & 57 & May & 29,1968 & 31 & .46 & 16 & .3 & 3.7 & .4 & 52 & 3.6 & 2.6 & .0 & .1 & 84 & 41 & 16 & .3 & .03 & 108 & -- & 6.7 \\
\hline 302 & 398. & 438 & Jan. & 16,1968 & 6.6 & -- & 7.0 & 1.2 & 399 & 2.1 & $452 \mathrm{~g}$ & .4 & 370 & 1.0 & .5 & 1,020 & 22 & 97 & 37 & 7.26 & 1,860 & 19 & 8.5 \\
\hline 401 & & 60 & Oct. & 27,1941 & -- & -- & 5.6 & 6.1 & 16 * & -- & 12 & 10 & 21 & 1.6 & 25.0 & 91 & 39 & -- & -- & - & -- & -- & -- \\
\hline 403 & $568-$ & 664 & Mar. & 14,1968 & 11.0 & .14 & 4.2 & .8 & 374 & 1.5 & 504 & .6 & 300 & 1.1 & .3 & 942 & 14 & 98 & 43 & 7.98 & 1,670 & 23 & 7.9 \\
\hline 601 & & 33 & Dec. & 5,1941 & -- & - & 23 & 12 & 5.8 * & -- & 12 & 2 & 20 & -. & 100 & 169 & 108 & -- & - & -- & -- & $-\cdot$ & -- \\
\hline 801 & & 20 & oct. & 27,1941 & -- & -- & 2.4 & 1.2 & $.2 *$ & -- & 6 & 2 & 3.0 & .2 & by & 12 & 11 & -- & -- & -- & -- & -- & - \\
\hline 802 & & 30. & Oct. & 5,1941 & -. & -- & 4.4 & 3.9 & 11 * & -- & 24 & 5 & 9.5 & .1 & 14 & 60 & 27 & -- & -- & - & -- & -- & - \\
\hline $55-801$ & $670=$ & 720 & Mar. & 7,1968 & - & - & -. & - & -. & -- & 344 & 3.2 & 172 & -. & $\cdots$ & $\cdots$ & 7 & -. & -. & 5.50 & 1,080 & 23 & 7.6 \\
\hline 901 & $370-$ & 400 & & do & 9.8 & .14 & .5 & .1 & 51 & 1.3 & 123 & 8.4 & 1.8 & .1 & 1.2 & 134 & 2 & 97 & 16 & 1.98 & 220 & 21 & 7.2 \\
\hline $56-201$ & & - & oct. & 27,1941 & $-\cdot$ & -- & 2.8 & 3.6 & $69 *$ & -- & 177 & 2 & 17 & -- & b) & 181 & 22 & -- & -. & -- & -- & 19 & -- \\
\hline 501 & & 24 & & do & -- & -- & 2.8 & 2.4 & 4.4 * & -. & 6 & 3 & 13 & .2 & by & 29 & 17 & -- & $-\cdot$ & -- & -- & -. & -- \\
\hline 801 & & 74 & Mar. & 19,1968 & 16 & .03 & 26 & 1.4 & 3.1 & 1.5 & 90 & .8 & 2.6 & .0 & .2 & 96 & 71 & 9 & .2 & .06 & 154 & -. & 7.3 \\
\hline
\end{tabular}

See footnotes at end of table. 


\begin{tabular}{|c|c|c|c|c|c|c|c|c|c|c|c|c|c|c|c|c|c|c|c|c|c|c|c|c|c|c|}
\hline 품 & : & $i$ & i & i & i & : & : & : & $i$ & ì & i & : & $i$ & : & i & $\stackrel{\infty}{\stackrel{\infty}{n}}$ & $\stackrel{2}{\stackrel{2}{*}}$ & $\stackrel{+}{\infty}$ & $:$ & $\stackrel{2}{2}$ & : & $: \begin{array}{l}\circ \\
1 \\
\end{array}$ & 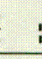 & : & $:$ & : \\
\hline 递崖 & : & : & : & ! & ! & : & : & : & : & : & : & : & : & ! & i & ส & i & : & i & : & : & : : & : & : : & & \\
\hline 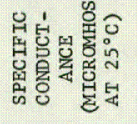 & i & : & : & $!$ & : & : & : & : & : & ఏ్తి & : & : & : & : & : & 高 & $\hat{\varrho}$ & : & : & $\stackrel{2}{7}$ & & : & & i : & & : \\
\hline 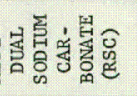 & : & : & : & i & : & : & : & : & : & : & : & : & ! & : & : & n. & ตे. & $:$ & : & ô. & : & $:$ & 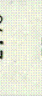 & : : & : & : \\
\hline 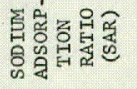 & : & : & i & i & : & : & i & : & : & $\stackrel{m}{0}$ & : & : & : & i & i & 요 & 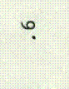 & : & i & z & i & : & 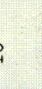 & : : & & : \\
\hline 总兽宫硈 & $:$ & $:$ & : & i & : & $:$ & : & $:$ & $:$ & 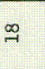 & $:$ & : & $:$ & : & : & $\stackrel{\infty}{\circ}$ & ลิ & : & $:$ & a & : & : & 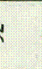 & : : & : & \\
\hline 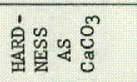 & శ్ & $\stackrel{\infty}{\curvearrowright}$ & $\stackrel{\infty}{\infty}$ & $\begin{array}{c}\infty \\
\text { in }\end{array}$ & 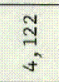 & $\infty$ & $\bar{z}$ & 9 & 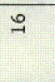 & $\bar{m}$ & $\approx$ & 6 & 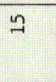 & 7 & $\approx$ & ${ }^{\circ}$ & in & 9 & ส & $0^{\circ}$ & \pm & $=7$ & 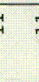 & 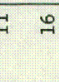 & & \\
\hline 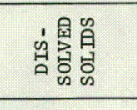 & ส & 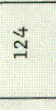 & $\stackrel{\circ}{\text { i }}$ & $\Xi$ & 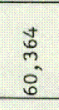 & 7 & i & F & $\vec{\sim}$ & $\cong$ & $\stackrel{1}{9}$ & 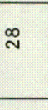 & 7 & $\vec{\sim}$ & $\stackrel{\infty}{\circ}$ & 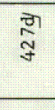 & ม & 帒 & กิ่ & ग्ले & $\therefore$ & $m \bar{~}$ & 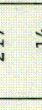 & $\vec{\sim}$ & & \\
\hline 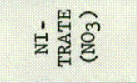 & $\stackrel{\infty}{q}$ & $q$ & $\stackrel{n}{m}$ & ? & $\circ$ & 웅 & $\rightarrow$ & $\stackrel{\circ}{i}$ & $\dot{i}$ & ִָ & $x$ & $\stackrel{0}{\circ}$ & $\stackrel{\circ}{\circ}$ & ix & 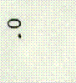 & ฯ & $\stackrel{9}{0}$ & $\because$ & $\stackrel{n}{i}$ & ב & $\approx$ & $\rightarrow \stackrel{\infty}{-}$ & & 우 & & \pm \\
\hline 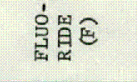 & i & : & : & : & $\overrightarrow{0}$ & : & $\uparrow$ & ฯ & : & $\stackrel{9}{9}$ & ฯ & $\because$ & : & ?. & : & $\stackrel{\varphi}{0}$ & ? & : & $\stackrel{0}{\circ}$ & $\stackrel{\circ}{\circ}$ & : & $\because$ & & : : & & : \\
\hline 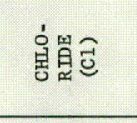 & $\stackrel{\infty}{\infty}$ & $\ddagger$ & $\approx$ & : & $\begin{array}{l}: \\
\vdots \\
\vdots\end{array}$ & 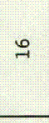 & ì & $\stackrel{\circ}{i}$ & $\stackrel{n}{i}$ & نे & $\stackrel{n}{i}$ & $\stackrel{n}{n}$ & $\stackrel{\circ}{i}$ & an & $\stackrel{ \pm}{ \pm}$ & $\infty$ & $\stackrel{a}{i}$ & 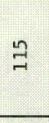 & $\stackrel{\infty}{=}$ & $\underset{\sim}{ \pm}$ & i & $\begin{array}{c}\circ \\
\stackrel{\circ}{\circ}+\infty \\
+\end{array}$ & & $\begin{array}{c}0 \\
-i \\
\end{array}$ & & $\stackrel{\circ}{\stackrel{2}{r}}$ \\
\hline 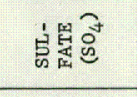 & a & m & $\infty$ & $=$ & $\sim$ & a & $\infty$ & a & in & t. & a & m & m & N & m & $\stackrel{\circ}{\dot{b}}$ & $\stackrel{0}{\dot{f}}$ & N & t & $\underset{-1}{2}$ & $\infty$ & $\approx$ & 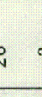 & m & & \\
\hline 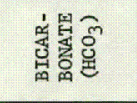 & $\circ$ & $\bullet$ & 。 & $\stackrel{\infty}{\infty}$ & $\stackrel{n}{i}$ & 0 & $\circ$ & 0 & $\circ$ & $\infty$ & $\approx$ & $\approx$ & $\stackrel{\infty}{-1}$ & $\stackrel{\infty}{-}$ & g & ले & \& & $\begin{array}{l}\text { का } \\
\text { क्ल }\end{array}$ & $\stackrel{\infty}{\circ}$ & よ & $\circ$ & - $\stackrel{\infty}{=}$ & 6 & $\because \approx$ & & $\approx$ \\
\hline 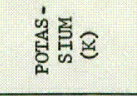 & i & : & : & : & : & : & : & : & i & $\exists$ & : & i & : & : & : & $\stackrel{\infty}{-}$ & $\stackrel{m}{m}$ & : & : & $\underset{-1}{I}$ & : & $: 3$ & n & : : & & : \\
\hline 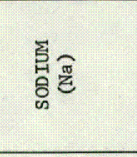 & $\stackrel{*}{\dot{m}}$ & * & $*$ & $*$ & $\begin{array}{l}* \\
* \\
0 \\
\tilde{a} \\
\dot{n}\end{array}$ & $\stackrel{*}{*}+$ & * & * & * & $\ddot{m}$ & $\begin{array}{l}* \\
* \\
- \\
-\end{array}$ & $\stackrel{*}{*}$ & * & 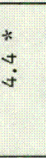 & & 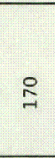 & $\Rightarrow$ & $\begin{array}{l}* \\
\tilde{N}\end{array}$ & $\begin{array}{l}* \\
\text { * } \\
\text { : }\end{array}$ & มี & * & 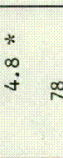 & & 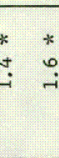 & & \\
\hline 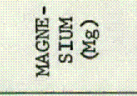 & $\simeq$ & \pm & $\overline{4}$ & $\stackrel{\circ}{\text { i }}$ & $\stackrel{ \pm}{2}$ & in & $\stackrel{4}{4}$ & 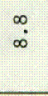 & $\hat{i}$ & ๆ. & $\stackrel{4}{i}$ & $\stackrel{n}{-1}$ & ฯ & i & $\stackrel{\Im}{\hookrightarrow}$ & " & $\stackrel{m}{j}$ & 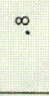 & $\stackrel{+}{i}$ & ? & ๓ & $\vec{j}$ & ? & $=-$ & & $\vec{n}$ \\
\hline 爮突 & $\stackrel{\infty}{\dot{j}}$ & 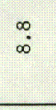 & \%) & \pm & 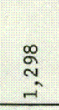 & $\begin{array}{l}\infty \\
i \\
i\end{array}$ & $\stackrel{\infty}{i}$ & $\stackrel{\circ}{-}$ & 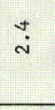 & I & $\infty$ & 。 & in & $\stackrel{\infty}{\infty}$ & i & $\stackrel{n}{-i}$ & I & $\stackrel{\leftrightarrow}{i}$ & $\stackrel{\infty}{\mathfrak{f}}$ & $\stackrel{i}{i}$ & $\overrightarrow{4}$ & का & & $\stackrel{0}{-} \stackrel{0}{j}$ & & $\stackrel{-}{9}$ \\
\hline 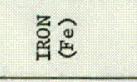 & : & : & : & 웅 & : & : & : & : & : & $\vec{m}$ & & : & : & : & $\stackrel{0}{?}$ & สุ & : & $\hat{\circ}$ & : & ఝุ. & : & : : & : & : : & & : \\
\hline 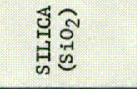 & : & : & : & 9 & : & : & : & : & : & $\approx$ & & : & : & : & i & 9 & ๙ั & 오 & : & $\exists$ & i & $:$ & $=$ & : : & & : \\
\hline 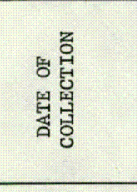 & $\begin{array}{l}\vec{J} \\
\text { ఏ } \\
\infty \\
\dot{0} \\
\stackrel{0}{0}\end{array}$ & $\because$ & $\because$ & 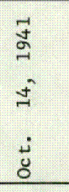 & 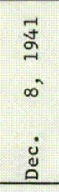 & : & 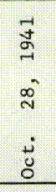 & $\begin{array}{l}\vec{J} \\
\text { a } \\
\sigma \\
\dot{\Xi} \\
\stackrel{0}{0}\end{array}$ & 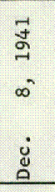 & $\begin{array}{l}\overrightarrow{0} \\
\text { - } \\
\hat{\sim} \\
\overrightarrow{3} \\
\overrightarrow{3}\end{array}$ & 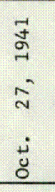 & 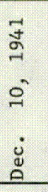 & 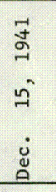 & 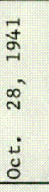 & $\begin{array}{l}\vec{\Xi} \\
\text { वे } \\
\text { वे } \\
\dot{0} \\
\end{array}$ & 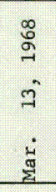 & 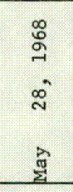 & $\begin{array}{l}\vec{\Xi} \\
\text { क } \\
\infty \\
\dot{5} \\
\end{array}$ & 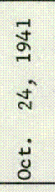 & 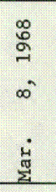 & 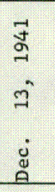 & 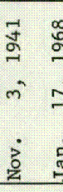 & & 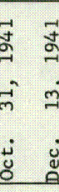 & & 요 \\
\hline 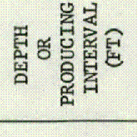 & $\ddot{A}$ & ก & มี & 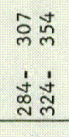 & कू & มี & 7 & g̊ & $\exists$ & 8 & ก & $\stackrel{\text { i }}{ }$ & ळे & ᄋ & 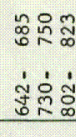 & & $\begin{array}{l}\vec{y} \\
\vec{a}\end{array}$ & $\begin{array}{l}\aleph^{\circ} \\
\dot{n}\end{array}$ & $\begin{array}{l}\text { ळొ } \\
\dot{\beta} \\
\dot{n}\end{array}$ & $\begin{array}{l}\text { ळे } \\
\text { ठ் } \\
\end{array}$ & ने & స & & ) & & సे \\
\hline 㽣 & 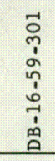 & $\vec{b}$ & ฮั & $\vec{\Omega}$ & $\begin{array}{l}\overrightarrow{0} \\
\dot{1} \\
\dot{0}\end{array}$ & $\overrightarrow{\mathrm{a}}$ & $\overrightarrow{\mathrm{n}}$ & $\vec{b}$ & $\vec{\infty}$ & క̆ & $\begin{array}{l}\overrightarrow{0} \\
\stackrel{0}{0} \\
\end{array}$ & : & ఫิ & $\vec{\circ}$ & $\vec{\Omega}$ & 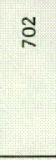 & ฐี่ & $\vec{d}$ & $\vec{i}$ & $\overrightarrow{0}$ & $\overline{5}$ & $\overrightarrow{0}$ & 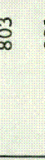 & పే \% & & 宗 \\
\hline
\end{tabular}


Table 9.--Chemical Analyses of Water From We1ls and Springs in Cass and Marion Counties--Continued

\begin{tabular}{|c|c|c|c|c|c|c|c|c|c|c|c|c|c|c|c|c|c|c|c|c|c|c|}
\hline WELL & $\begin{array}{c}\text { DEPTH } \\
\text { OR } \\
\text { PRODUCING } \\
\text { INTERVAL } \\
\text { (FT) }\end{array}$ & & $\begin{array}{l}\text { ATE OF } \\
\text { LLECTION }\end{array}$ & $\begin{array}{l}\text { SILICA } \\
\left(\mathrm{SiO}_{2}\right)\end{array}$ & $\begin{array}{l}\text { IRON } \\
(\mathrm{Fe})\end{array}$ & $\begin{array}{l}\text { CAL- } \\
\text { CIUM } \\
\text { (Ca) }\end{array}$ & $\begin{array}{l}\text { MAGNE- } \\
\text { SIUM } \\
\text { (Mg) }\end{array}$ & $\begin{array}{l}\text { SoDIuM } \\
\text { (Na) }\end{array}$ & $\begin{array}{l}\text { POTAS- } \\
\text { SIUM } \\
\text { (K) }\end{array}$ & $\begin{array}{l}\text { BICAR- } \\
\text { BONATE } \\
\left(\mathrm{HCO}_{3}\right)\end{array}$ & $\begin{array}{l}\text { SUL- } \\
\text { FATE } \\
\left(\mathrm{SO}_{4}\right)\end{array}$ & $\begin{array}{l}\text { CHLO- } \\
\text { RIDE } \\
\text { (C1) }\end{array}$ & $\begin{array}{l}\text { FLUO- } \\
\text { RIDE } \\
\text { (F) }\end{array}$ & $\begin{array}{c}\text { NI- } \\
\text { TRATE } \\
\left(\mathrm{NO}_{3}\right)\end{array}$ & $\begin{array}{l}\text { DIS- } \\
\text { SOLVED } \\
\text { SOLDSS }\end{array}$ & $\begin{array}{l}\text { HARD- } \\
\text { NESS } \\
\mathrm{AS} \\
\mathrm{CaCO}_{3}\end{array}$ & $\begin{array}{l}\text { PER- } \\
\text { CENT } \\
\text { SO- } \\
\text { DIUM }\end{array}$ & $\begin{array}{l}\text { SODIUM } \\
\text { ADSORP- } \\
\text { TION } \\
\text { RATIO } \\
\text { (SAR) }\end{array}$ & $\begin{array}{l}\text { RESI- } \\
\text { DUAL } \\
\text { SODIUM } \\
\text { CAR- } \\
\text { BONATE } \\
\text { (RSC) }\end{array}$ & $\begin{array}{l}\text { SPECIF IC } \\
\text { CONDUCT - } \\
\text { ANCE } \\
\text { (MICROMHOS } \\
\text { AT } 25^{\circ} \mathrm{C} \text { ) }\end{array}$ & $\begin{array}{l}\text { TEMPER - } \\
\text { ATURE }\end{array}$ & $\mathrm{pH}$ \\
\hline DB-16-64-201 & $\begin{array}{ll}350- & 360 \\
375- & 395 \\
425- & 440\end{array}$ & & 19,1968 & 9.9 & 0.15 & 4.2 & 1.2 & 55 & 2.8 & 151 & 9.6 & 3.9 & 0.4 & 0.1 & 161 & 15 & 86 & 6.2 & 2.17 & 264 & 22 & 7.6 \\
\hline 203 & 19 & Dec. & 13,1941 & - & -- & 10 & 2.7 & $22 *$ & - & 61 & 20 & 9.0 & - & 1.0 & 95 & 37 & -- & - & -. & -- & -- & -- \\
\hline 501 & $200-214$ & May & 29,1968 & 11 & .52 & 9.2 & 2.6 & 42 & 2.8 & 121 & 19 & 6.8 & .1 & .1 & 154 & 34 & 71 & 3.1 & 1.31 & 263 & -- & 7.7 \\
\hline $35-04-401$ & 24 & Dec. & 6,1941 & -. & -. & 4.4 & 3.9 & 4.4 * & $-\cdot$ & 12 & 3 & 10 & $\cdots$ & 12 & 44 & 27 & -- & -- & -- & -- & -- & -- \\
\hline 601 & -- & oct. & 28,1941 & -- & -- & 1.2 & 3.4 & 71 * & -- & 177 & 18 & 4.5 & .1 & b & 185 & 17 & -- & -- & -. & -- & -- & -. \\
\hline 601 & - & Apr. & 10,1968 & -. & -- & -- & -- & -- & -- & 156 & -. & 3.3 & $-\cdot$ & -- & $-\cdot$ & 6 & -- & -- & 2.44 & 286 & 19 & 7.6 \\
\hline 801 & $360-380$ & oct. & 28,1941 & - & $-\cdot$ & 6.4 & 1.2 & 38 * & -- & 98 & 15 & 6.0 & .3 & by & 115 & 22 & -- & -. & -- & -. & -. & -. \\
\hline 803 & $271-\quad 321$ & Apr. & 8,1968 & 10 & .21 & 1.0 & .6 & 45 & 1.8 & 104 & 13 & 2.8 & .3 & .6 & 126 & 5 & 93 & 8.7 & 161 & 204 & -- & 7.6 \\
\hline 901 & 19 & Dec. & 6,1941 & $\cdots$ & -- & 2.8 & 12 & $42 *$ & $-\cdot$ & 6 & 6 & 80 & -. & 32 & 178 & 58 & -. & -. & - & -- & -- & - \\
\hline $05-301$ & 25 & Dec. & 4,1941 & -- & -- & 2.4 & 3.9 & $21 *$ & - & 6 & 4 & 22 & -. & 34 & 100 & 22 & -. & - & -- & -- & $\cdots$ & -. \\
\hline 302 & 49 & & do & - & $-\cdot$ & 4.0 & 10 & $4.4 *$ & -- & 18 & 2 & 31 & -- & 54 & 134 & 51 & -- & - & - & -. & - & -- \\
\hline $06-102$ & 260 & May & 31,1968 & 11 & .11 & 4.5 & 1.6 & 50 & 3.3 & 153 & .2 & 3.4 & .2 & .7 & 150 & 18 & 83 & 5.1 & 2.15 & 253 & -- & 7.4 \\
\hline 201 & 51 & & do & 12 & 1.6 & 3.0 & 1.0 & 1.3 * & .4 & 12 & .2 & 3.2 & .0 & 1.2 & 28 & 12 & 19 & .2 & .00 & 34 & $-\cdot$ & 6.5 \\
\hline 301 & 27 & Dec. & 3, 1941 & -- & -- & 6 & 1.5 & 14 * & -- & 37 & 3 & 10 & -. & 6.0 & 59 & 21 & -- & -- & - & -- & -- & -- \\
\hline 402 & Spring & & do & $-\cdot$ & -- & a) & .2 & 10 * & -- & 12 & 2 & 6.0 & -- & 3.0 & 24 & 1 & -- & - & -. & - & -- & -- \\
\hline 701 & 21 & Dec. & 4,1941 & -- & -- & 4.0 & 1.5 & $5.3 *$ & -- & 18 & 2 & 3.0 & .1 & 8.0 & 33 & 16 & -. & -- & -- & -- & - & -- \\
\hline 801 & 26 & Dec. & 2, 1941 & -- & -- & 4.0 & 1.5 & $5.3 *$ & -. & 18 & 7 & 3.0 & -. & 1.5 & 31 & 16 & -- & -. & -. & - & -- & -- \\
\hline 802 & $680-760$ & Mar. & 25,1968 & $-\cdot$ & $-\cdot$ & $-\cdot$ & -. & $-\cdot$ & -- & 482 & $-\cdot$ & 332 & -- & -- & -- & 8 & -- & -- & 7.74 & 1,740 & -- & 8.0 \\
\hline 901 & $600-630$ & & do & - & - & -- & -- & $-\cdot$ & $-\cdot$ & 510 & $-\cdot$ & 402 & $-\cdot$ & -- & -- & 11 & -- & -- & 8.14 & 1,980 & 25 & 8.2 \\
\hline $07-703$ & $515-572$ & Mar. & 26,1968 & 11 & .06 & 3.0 & .5 & 394 & 1.6 & 538 & .2 & 300 & 1.2 & .9 & 977 & 10 & 99 & 54 & 8.63 & 1,730 & 24 & 8.1 \\
\hline 704 & $256-287$ & & do & 12 & .06 & 3.2 & .7 & 308 & 1.9 & $528 \mathrm{~g}$ & .0 & 182 & 1.3 & 1.3 & 770 & 11 & 98 & 40 & 8.45 & 1,320 & 21 & 8.4 \\
\hline 801 & $595-701$ & & 1,1968 & - & - & -- & -- & $-\cdot$ & - & 576 & - & 495 & - & -- & -- & 16 & -- & -- & 9.12 & 2,390 & 23 & 7.9 \\
\hline 901 & $254-300$ & May & 29,1968 & 10 & -- & 3.2 & .7 & 242 & 2.1 & 532 & .0 & 75 & 1.7 & 2.8 & 600 & 11 & 98 & 32 & 8.50 & 1,030 & 20 & 8.1 \\
\hline 903 & 1,000 & & do & 17 & - & 4.0 & 1.3 & 272 & 2.3 & 374 & .0 & 220 & 1.1 & 2.3 & 704 & 16 & 97 & 30 & 5.82 & 1,280 & 22 & 7.6 \\
\hline $08-101$ & $270-330$ & & 17,1968 & 11 & - & 2.5 & .5 & 98 & 2.0 & 258 & .0 & 5.2 & .4 & .0 & 247 & 8 & 95 & 15 & 4.06 & 413 & 20 & 7.9 \\
\hline 501 & 708 & Nov. & 4, 1941 & - & -- & a) & 1.7 & 370 * & -- & 451 & 2 & 310 & 1.2 & b) & 907 & 7 & -- & - & -. & -. & -. & -. \\
\hline 501 & 708 & Mar. & 22,1968 & 12 & .06 & 2.8 & 3.9 & 370 & 1.6 & 468 & .0 & 312 & 1.1 & 1.2 & 935 & 23 & 97 & 34 & 7.21 & 1,680 & 24 & 8.2 \\
\hline
\end{tabular}

See footnotes at end of table. 


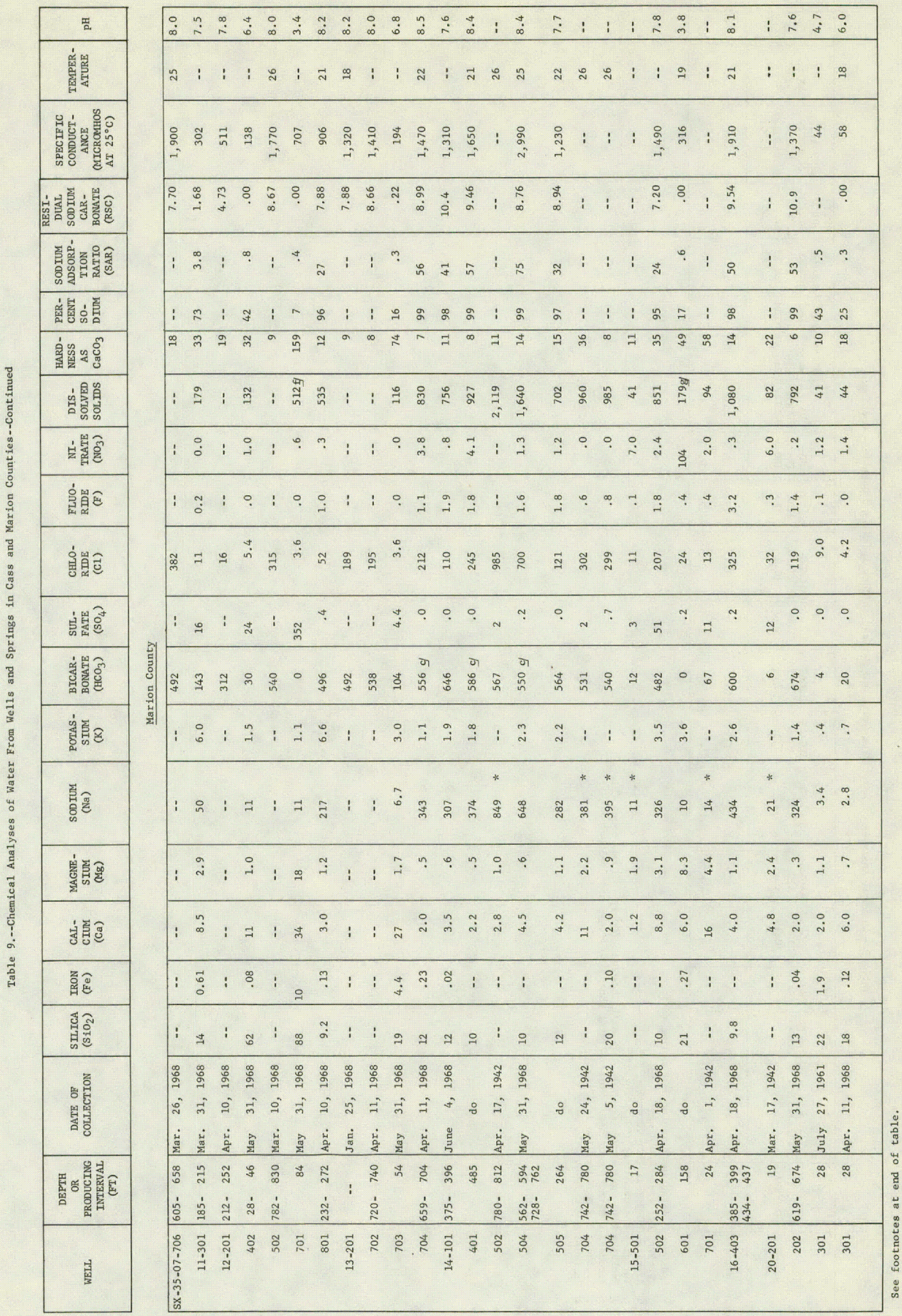


Table 9.--Chemical Analyses of Water From Wells and Springs in Cass and Marion Counties--Continued

\begin{tabular}{|c|c|c|c|c|c|c|c|c|c|c|c|c|c|c|c|c|c|c|c|c|c|}
\hline WELL & $\begin{array}{c}\text { DEPTH } \\
\text { OR } \\
\text { PRODUCING } \\
\text { INTERVAL } \\
\text { (FT) }\end{array}$ & $\begin{array}{l}\text { DATE OF } \\
\text { COLLECTION }\end{array}$ & $\begin{array}{l}\text { SIIICA } \\
\left(\mathrm{SiO}_{2}\right)\end{array}$ & $\begin{array}{l}\text { IRON } \\
(\mathrm{Fe})\end{array}$ & $\begin{array}{l}\text { CAL- } \\
\text { CIUM } \\
\text { (Ca) }\end{array}$ & $\begin{array}{l}\text { MAGNE- } \\
\text { SIUM) } \\
\text { (Mg) }\end{array}$ & $\begin{array}{l}\text { SODIUM } \\
\text { (Na) }\end{array}$ & $\begin{array}{l}\text { POTAS- } \\
\text { SIUM } \\
\text { (K) }\end{array}$ & $\begin{array}{l}\text { BICAR- } \\
\text { BONATE }\left(\mathrm{HCO}_{3}\right)\end{array}$ & $\begin{array}{l}\text { SUL- } \\
\text { FATE } \\
\left(\mathrm{SO}_{4}\right)\end{array}$ & $\begin{array}{l}\text { CHLO- } \\
\text { RIDE } \\
\text { (C1) }\end{array}$ & $\begin{array}{l}\text { FLUO- } \\
\text { RDE } \\
\text { (F) }\end{array}$ & $\begin{array}{c}\text { NI- } \\
\text { TRATE } \\
\left(\mathrm{NO}_{3}\right)\end{array}$ & $\begin{array}{l}\text { DIS- } \\
\text { SOLVED } \\
\text { SOLIDS }\end{array}$ & $\begin{array}{l}\text { HARD- } \\
\text { NESS } \\
\mathrm{AS} \\
\mathrm{CaCO}_{3}\end{array}$ & $\begin{array}{l}\text { PER- } \\
\text { CENT } \\
\text { SO- } \\
\text { DIUM }\end{array}$ & $\begin{array}{l}\text { SOD IUM } \\
\text { ADSORP- } \\
\text { TION } \\
\text { RATIO } \\
\text { (SAR) }\end{array}$ & $\begin{array}{l}\text { RESI- } \\
\text { DUAL } \\
\text { SODIUM } \\
\text { CAR- } \\
\text { BONATE } \\
\text { (RSC) }\end{array}$ & $\begin{array}{l}\text { SPECIFIC } \\
\text { CONDUCT - } \\
\text { ANCE } \\
\text { MICROMHOS } \\
\text { AT } 25^{\circ} \mathrm{C} \text { ) }\end{array}$ & $\begin{array}{l}\text { TEMPER- } \\
\text { ATURE }\end{array}$ & $\mathrm{pH}$ \\
\hline SX $-35-21-301$ & $318-\quad 348$ & June $\quad 4,1968$ & 11 & -- & 3.2 & .6 & 412 & 2.1 & 508 & .2 & 350 & .9 & 3.9 & 1,030 & 10 & 99 & 57 & 8.12 & 1,880 & -- & 7.5 \\
\hline 501 & 32 & Mar. 17,1942 & -- & -- & a) & 1.2 & $11 *$ & -- & 12 & 3 & 5.0 & .2 & 10 & 36 & 5 & -- & -- & -- & -- & -- & -. \\
\hline
\end{tabular}

* Sodium and potassium calculated as sodium (Na).

a Calcium (Ca) less than $5 \mathrm{mg} / 1$.

firctite

d/ Includes $0.03 \mathrm{mg} / 1$ manganese $(\mathrm{Mn}), 0.77 \mathrm{mg} / 1$ phosphate $\left(\mathrm{PO}_{4}\right)$, and 0.37 boron (B)

of Includes $0.05 \mathrm{mg} / 1$ manganese $(\mathrm{Mn}), 1.2 \mathrm{mg} / 1$ phosphate ( $\mathrm{PO} 4)$, and 0.43 boron (B).

Includes $3.7 \mathrm{mg} / 1$ acidity as $\mathrm{H}+1$.

g Includes $1.1 \mathrm{mg} / 1$ acidity as $\mathrm{H}^{+1}$ 


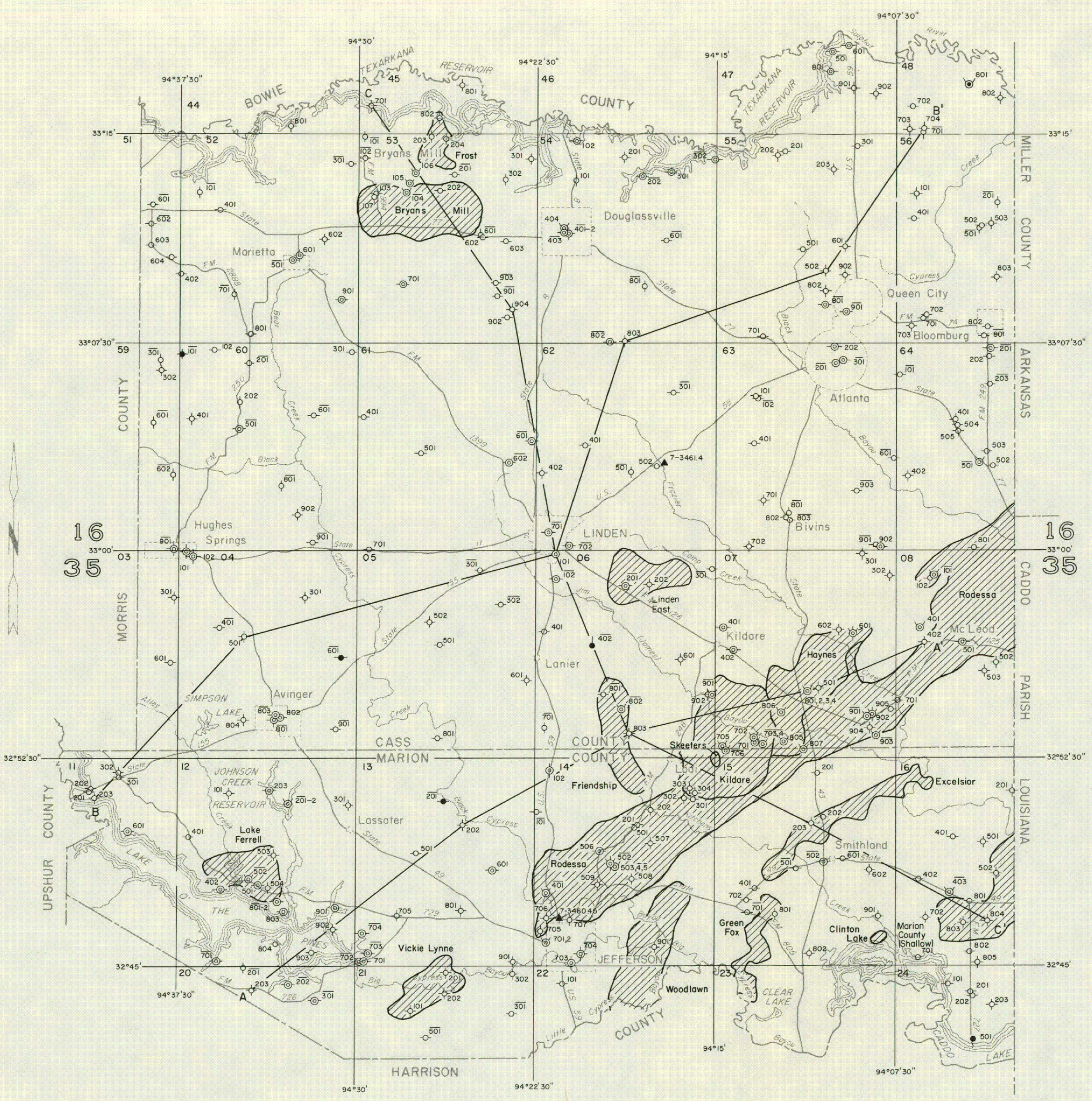

EXPLANATION

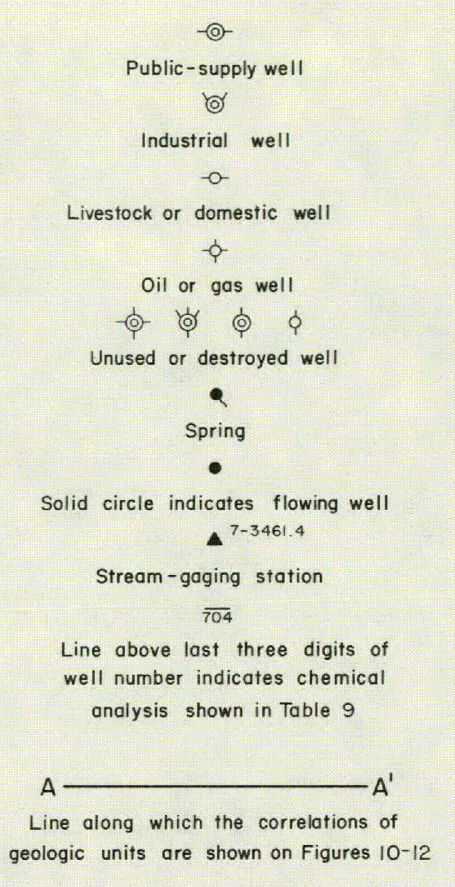

Rodess 



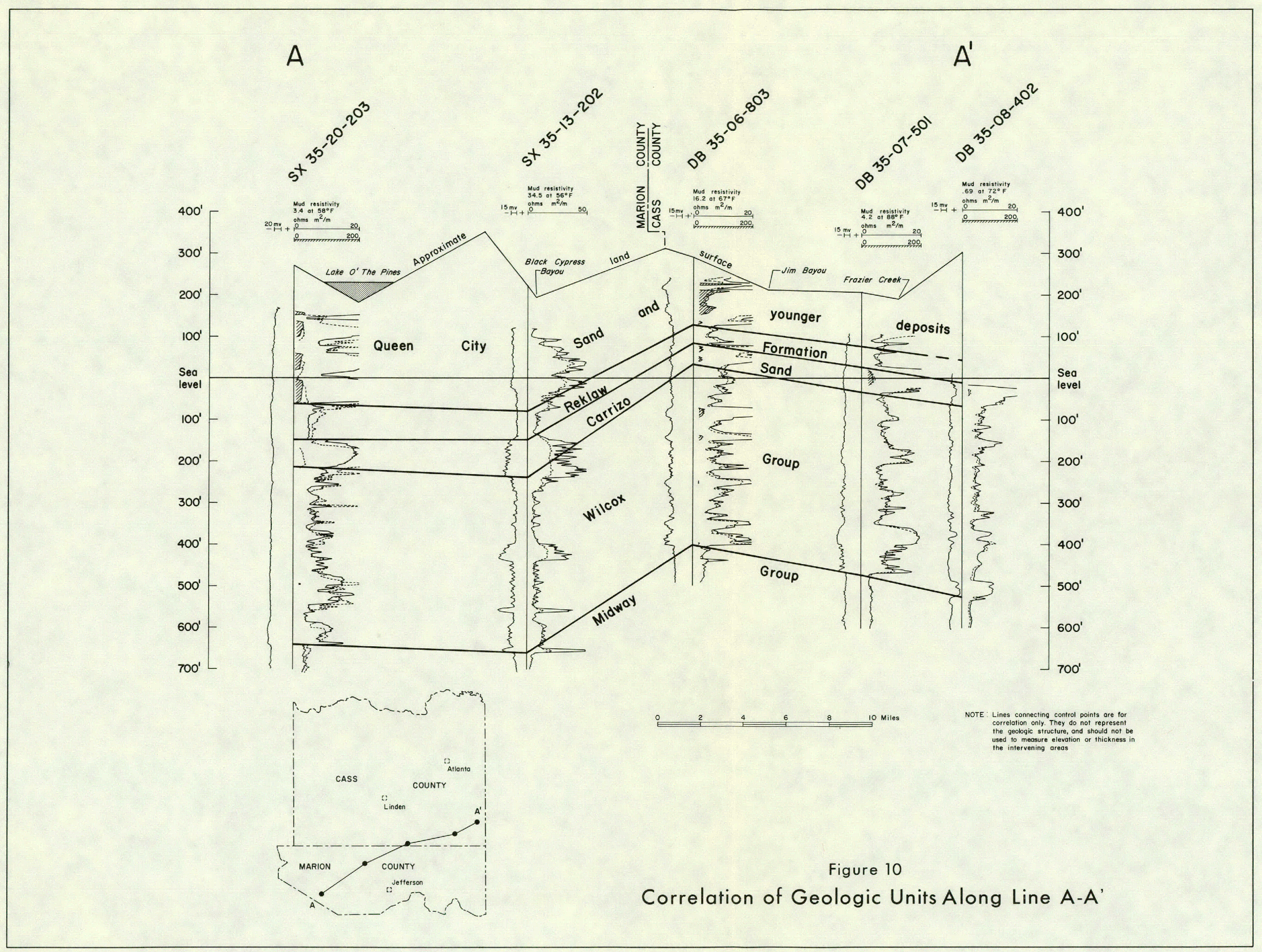





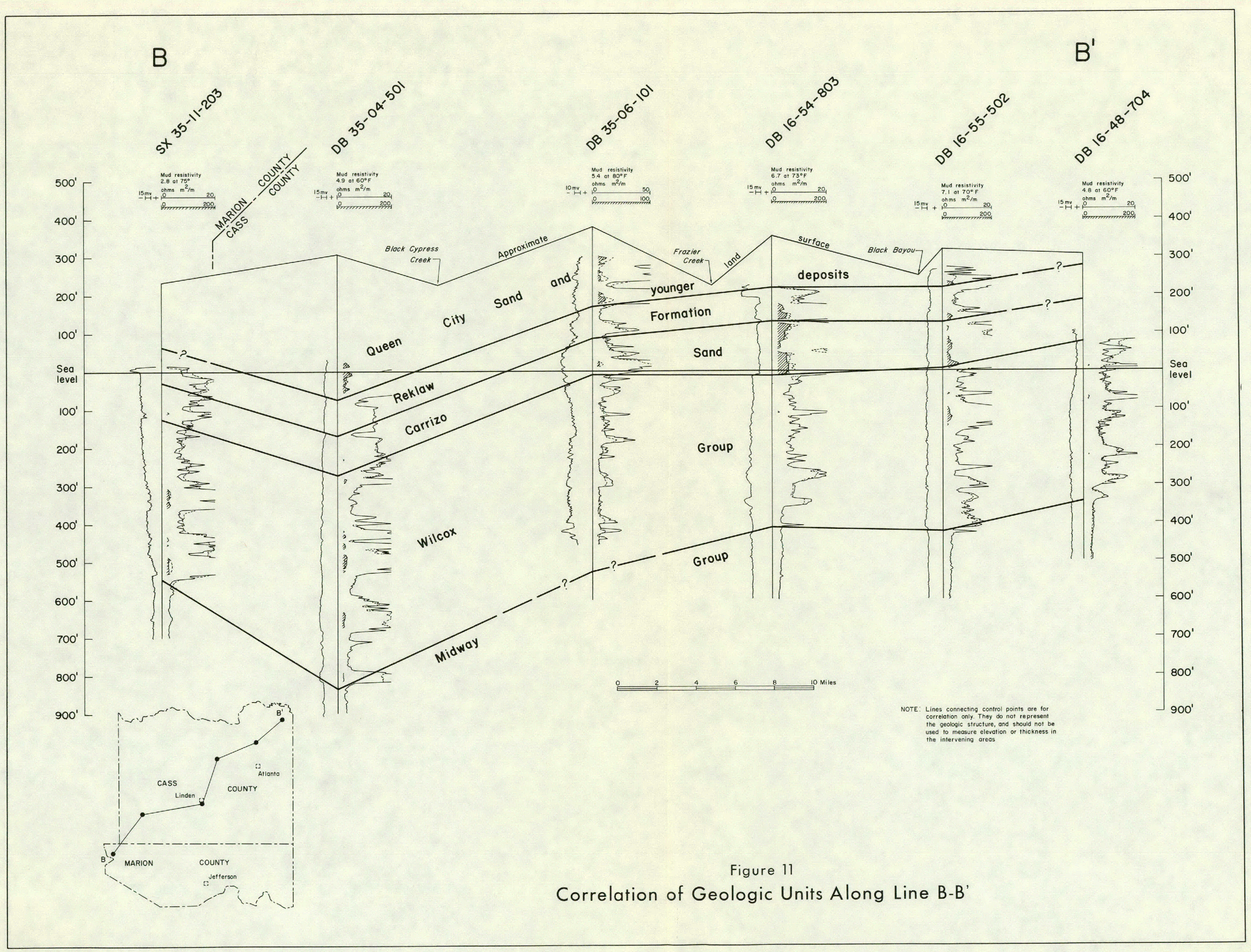





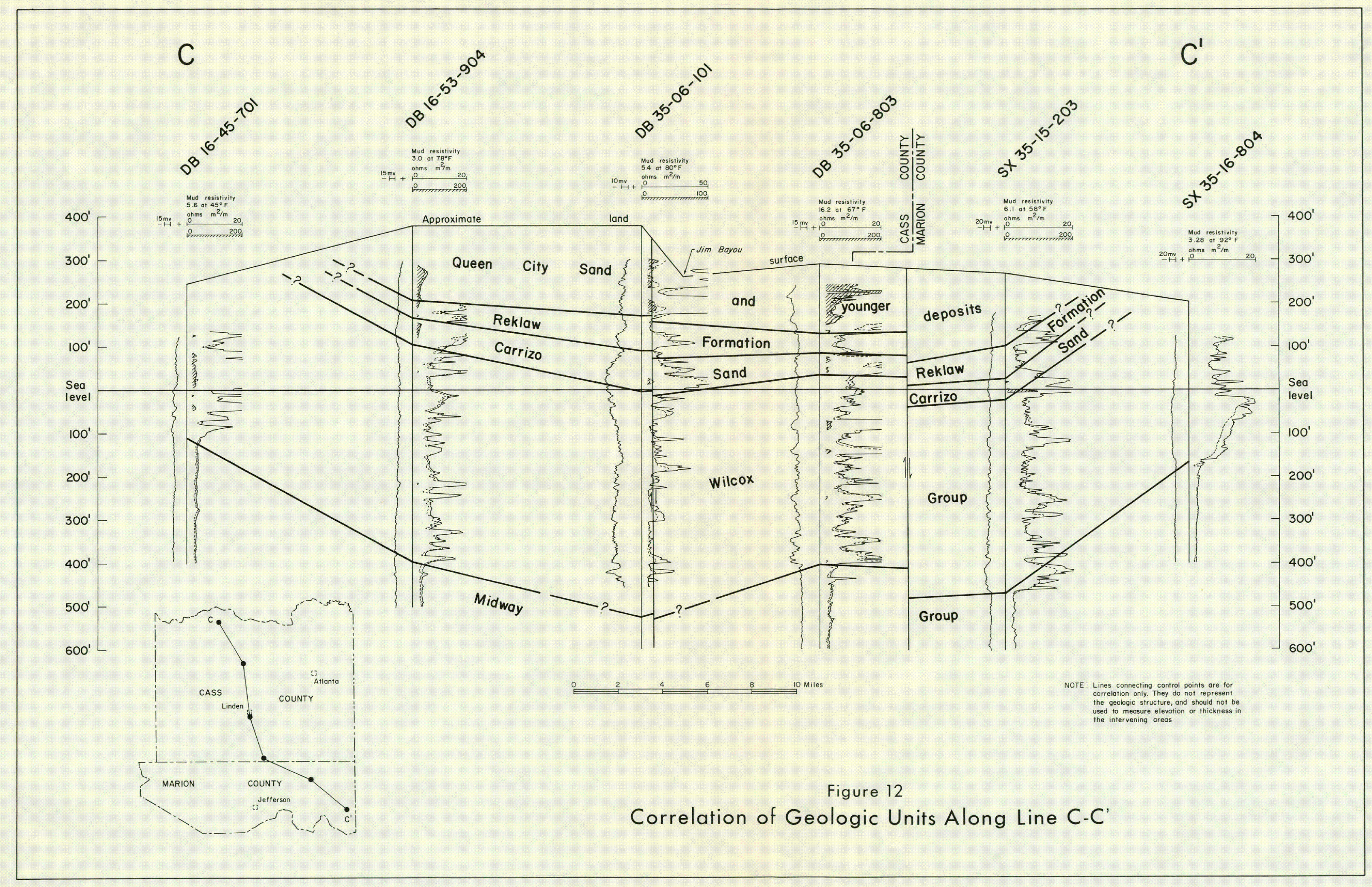




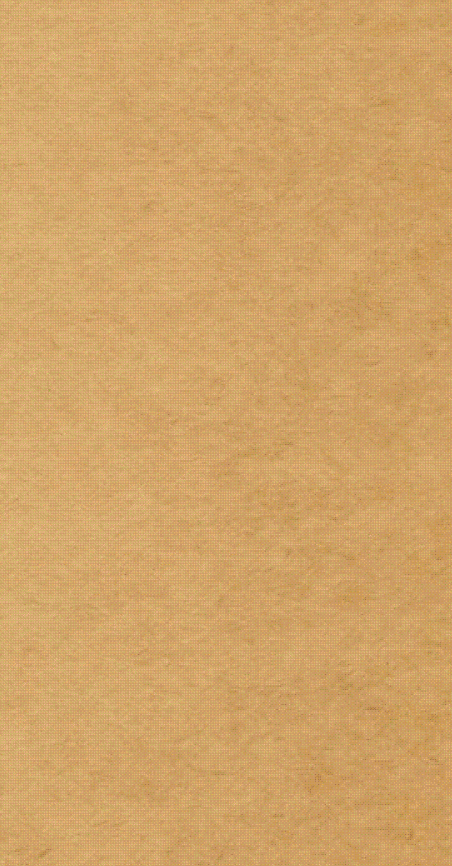


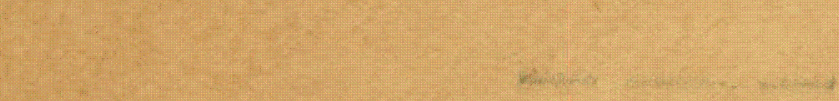

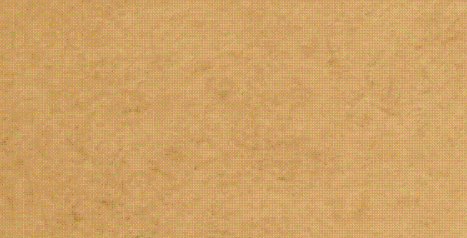

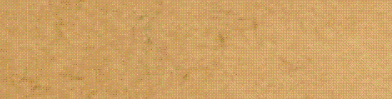

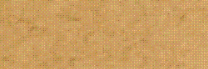

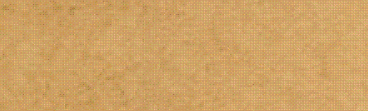

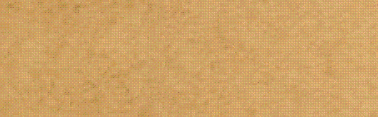

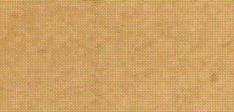

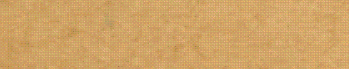

$x^{2}+2=0$ 